There is no doubt, firms acknowledge the importance of innovation for survival and growth. They spend up to $25 \%$ of their revenue on research and development (R\&D) and R\&D spending continues to increase in all regions and nearly all industries. Unfortunately, innovation excellence cannot just be bought by spending more dollars on R\&D. Despite the enormous amounts of money involved and a rich source of managerial literature that asks firms to invest in innovation and promises success in return, firms continue to struggle in capturing value from their innovation efforts. Innovation remains a difficult and often frustrating task for many of them. Innovation requires strategy. This dissertation focuses on effective innovation strategies for incumbent firms or innovation strategies that pay off.

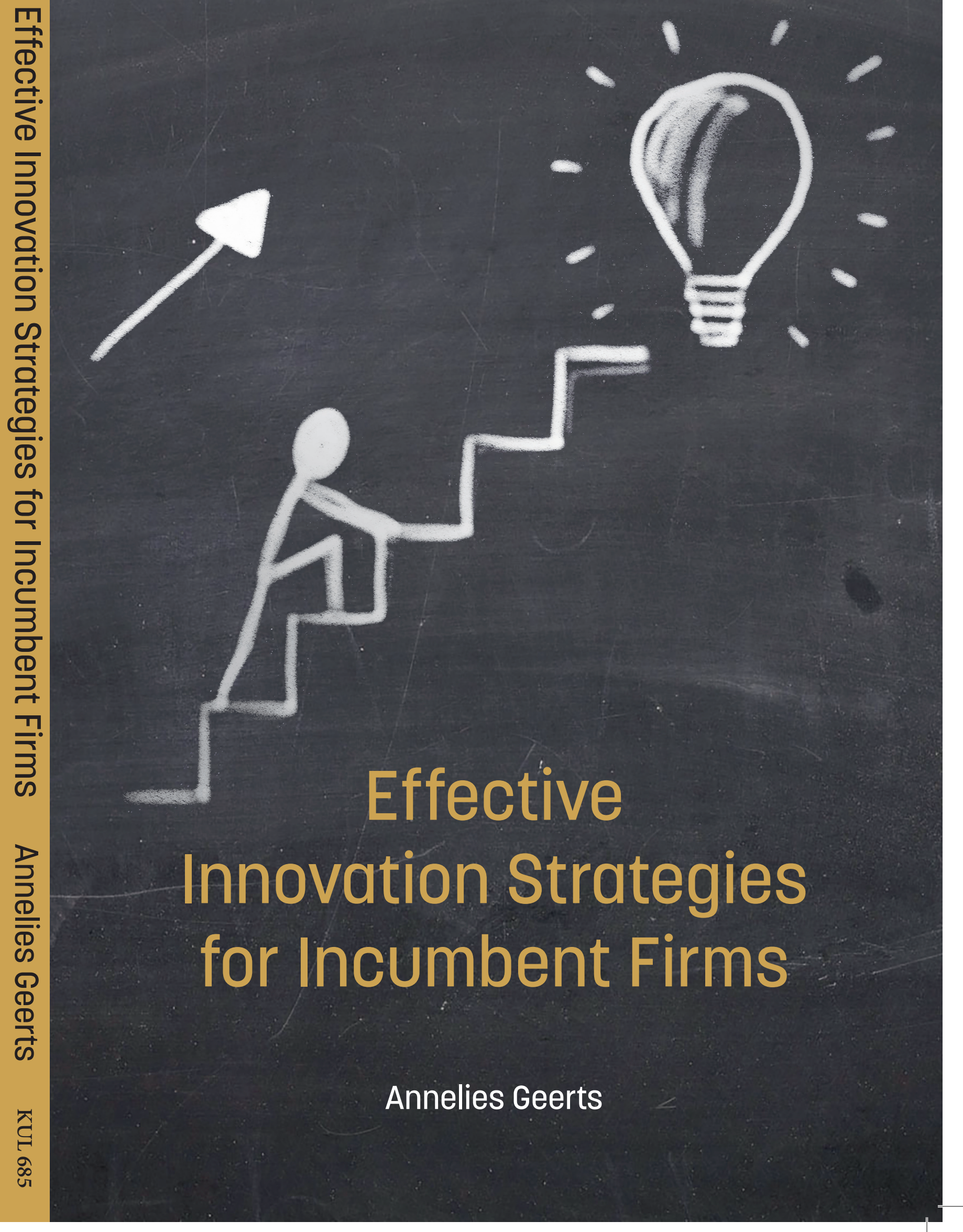




\section{EFFECTIVE INNOVATION STRATEGIES FOR INCUMBENT FIRMS}

Annelies Geerts 
ISBN: 978-90-365-4917-2

DOI: $10.3990 / 1.9789036549172$

(C) 2019 Leuven, Belgium. All rights reserved. No parts of this thesis may be reproduced, stored in a retrieval system or transmitted in any form or by any means without permission of the author. Alle rechten voorbehouden. Niets uit deze uitgave mag worden vermenigvuldigd, in enige vorm of op enige wijze, zonder voorafgaande schriftelijke toestemming van de auteur. 


\title{
EFFECTIVE INNOVATION STRATEGIES FOR INCUMBENT FIRMS
}

\author{
DISSERTATION
}

to obtain

the degree of doctor at the University of Twente,

on the authority of the rector magnificus,

prof. dr. T.T.M. Palstra,

on account of the decision of the Doctorate Board,

to be publicly defended

on Friday, the 20th of December 2019 at 14.45 hrs

by

\section{Annelies Annie Cyriel Geerts}

born on $16^{\text {th }}$ of October 1984

in Knokke-Heist, Belgium 


\title{
EFFECTIVE INNOVATION STRATEGIES FOR INCUMBENT FIRMS
}

\author{
DISSERTATION
}

to obtain

the degree of Doctor in Business Economics at the Catholic University of Leuven

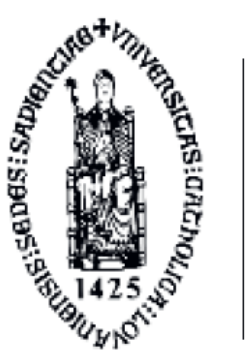

KU Leuven

Faculty of Economics and

Business

by

\section{Annelies Geerts}

born on $16^{\text {th }}$ of October 1984

in Knokke-Heist, Belgium 
This dissertation has been approved by:

\section{Supervisors}

prof. dr. ir. P.C. de Weerd-Nederhof prof. dr. B. Van Looy

Co-supervisor

dr. ir. K. Visscher 


\section{GRADUATION COMMITTEE}

Chairman prof. dr. T.A.J. Toonen University of Twente

Supervisors prof. dr. ir. P.C. de Weerd-Nederhof prof. dr. B. Van Looy

Co-supervisor dr. ir. K. Visscher

prof. dr. ir. J. Henseler prof. dr. ir. O.A.M. Fisscher prof. dr. R. Belderbos

prof. dr. B. Leten

prof. dr. H.J. Hultink

dr. ir. F. Blindenbach-Driessen
University of Twente

Catholic University of Leuven

University of Twente

University of Twente

University of Twente

Catholic University of Leuven

Catholic University of Leuven

Delft University of Technology

Organizing for Innovation LLC 


\section{SUMMARY}

There is no doubt, firms acknowledge the importance of innovation for survival and growth. They spend up to $25 \%$ of their revenue on research and development (R\&D) and R\&D spending continues to increase in all regions and nearly all industries (Jaruzelski, Chwalik, \& Goehle, 2018). Unfortunately, innovation excellence cannot just be bought by spending more dollars on R\&D. Despite the enormous amounts of money involved and a rich source of managerial literature that asks firms to invest in innovation and promises success in return, firms continue to struggle in capturing value from their innovation efforts. Innovation remains a difficult and often frustrating task for many of them.

Innovation requires strategy. However, firms often tend to overlook the importance of aligning their innovation activities with their business strategies. An important aspect of a firm's innovation strategy is how it intends to balance its exploitation and exploration activities in order to be effective in the short run and to survive and prosper in the long run (e.g. Gupta, Smith, \& Shalley, 2006; Luger, Raisch, \& Schimmer, 2018; March, 1991).

How can incumbent firms effectively pursue their innovation strategy and journey by making the right choices in terms of time, location, technology and path?

This dissertation focuses on effective innovation strategies for incumbent firms or innovation strategies that pay off. Four studies focus on different aspects of firm's innovation strategies. First, we apply a multilevel approach. Chapters two and three focus on the firm and its overall innovation behavior, chapters four and five focus on a particular innovation within the firm. These different views, i.e. broad and narrow or general and detailed, enable a comprehensive and thorough analysis concerning effective innovation strategies. Besides, we study firm strategies and practices in its geographical and industry context. Second, we look at four perspectives on effective innovation strategies: timing, location, technology and path to obtain in-depth insights into the complexity of managing and executing a firm's innovation strategy.

In sum, this dissertation concludes that in order to reach innovation strategy effectiveness, firms can engage in exploration and exploitation through a simultaneous or sequential way, should consider to opt for spatial proximity of their exploratory and exploitative activities, need to invest in technological development, and adjust these choices based on what happens during the execution of an innovation project.

A successful innovation journey from idea to market requires more than technological capabilities. While an innovation strategy or a sound innovation plan is crucial for each firm (in order to reach an outcome in accordance to the business strategy), a strategy is rarely implemented exactly as planned. Firms face unforeseen events along the innovation path. Both innovation strategy and innovation journey must constantly be coordinated.

The contribution of this dissertation is that it adds to the existing knowledge about how 
incumbent firms can effectively develop and enact an innovation strategy. Following prior research (e.g. Birkinshaw \& Gibson, 2004; Gupta, Smith, \& Shalley, 2006; Lavie, Stettner, \& Tushman, 2010; Luger, Raisch, \& Schimmer, 2018; Mathias, McKenny, \& Crook, 2018), the four empirical studies underline the importance for firms to combine exploratory and exploitative activities. The main contribution is therefore that this dissertation suggests how this can best be achieved and what aspects contribute to innovation strategy effectiveness.

The findings of the four studies provide useful managerial advice. All four studies show that it is a must for firms to invest in both exploratory and exploitative activities, regardless of being active in one or more emerging, new or mature markets, or being a service or manufacturing firm. The development of a strategy is not enough. In line with the managerial advice of for example Brandenburger (2019) and Pisano (2015), this dissertation shows that strategy effectiveness largely depends on its execution. Besides, the four studies reveal what exactly helps incumbent firms to experience an effective innovation journey and strategy.

What do timing, location, technology and path imply for managers that should develop and execute an innovation strategy? Relying on managerial judgement, available resources and environmental circumstances, firms can decide to follow a simultaneous our sequential approach in their exploration and exploitation efforts. Taking into account the firm- and industry specific context, both approaches seem to be equally viable.

When firms decide on the organizational set-up of their exploration and exploitation efforts, spatial proximity should be taken into account. Organizing for exploration and exploitation in spatial proximity facilitates spillovers and synergies which can lead to an elevated level of innovation performance, in addition to cost efficiency.

There is more than technology. It is important to be active in different technology fields, yet, at the same time, one might not lose focus.

Incumbent firms should consider a sophisticated and dynamic interplay of critical ingredients when carrying out an innovation trajectory. While executing upon their innovation strategy, organizational design, people, resources, operational flexibility and capabilities have to managed appropriately. 


\section{ACKNOWLEDGMENTS}

"Patience, persistence and perspiration make an unbeatable combination for success". This quote by Napoleon Hill translates what a Ph.D. trajectory looks like from start to finish. I am looking forward to celebrate and conclude this chapter of my career. This has been made possible by the commitment, involvement, and support of many people.

Petra de Weerd-Nederhof and Bart Van Looy, thank you for being my supervisors! Your enthusiasm, involvement, and wise advice meant a lot to me. Klaasjan Visscher, thank you for the informative and pleasant feedback moments. I learned a lot from Petra, Bart, and Klaasjan. You also gave me the opportunity to participate in other research projects besides my own Ph.D. research. I am also grateful for being given the opportunity to participate in congresses worldwide.

My career started in 2008 as a researcher at Vlerick Business School. During those fine years, I met Floortje Blindenbach-Driessen, prof. in Innovation Management. Soon we decided to work together and not much later the first Academy of Management Conference paper was a fact. This meant the start of an academic trajectory. One day our paths were separated, Floortje went to the US, I started with a Ph.D. at the University of Twente and the KU Leuven. We kept in touch. Floortje, you have played an important role as a sounding board and support in this whole Ph.D. story. I am very grateful to you.

My gratitude also goes out to the committee members: Rene Belderbos, Bart Leten, Erik-Jan Hultink, Jörg Henseler and Olaf Fisscher. Thank you for your dedication and valuable advice.

I would also like to thank my fine colleagues at the University of Twente and KU Leuven. Matthias, Erwin, Michel, Sandor, Maikel, Adrián, Julie, Caro, Xiaoyan, Isabelle, and everyone else. The pleasant atmosphere and enjoyable conversations made it a pleasure to work in Enschede and Leuven. Matthias, a special thank you for your hospitality in the Netherlands! You were a wonderful host.

I would also like to give a special word of thanks to my family and friends. My parents, brother, and sister-in-law, Isabel, have always supported me and enjoyed listening to new ideas, data discoveries of the day, and the typical Ph.D. frustrations. Your presence in this process was invaluable. Peter Cyriel, unfortunately you cannot see the end of my Ph.D. 'live' anymore, but know that you are my great example. Grandpa Jan, I am sure you are proud and are part of this event with a big smile. Grandma Rachel and Grandma Mieke, I could always come to you for a chat. You were perfectly aware of the evolution and themes of each research chapter. How nice it was to be able to talk about the research conclusions and congress trips over coffee and cake... I am so happy to be able to hand over the finished dissertation to you. 
Liesbeth, Caroline, Tim, Tom, Nolo, Nancy, Bieke, Bert, Evelyne, Michael, Katrien, Kathleen, Aude, Alex, Elke, Lieven, Trees, Thomas, Pascal, Brigitte, Sven and many others. Thank you for your support and friendship! Sorry for the regular absence during the past year. This is going to change.

Also a special word of thanks to my colleagues in Brussels. Peggy, Carine, Hilde, Greet, Tom, Johny, Elke, Karolien, Katrien, Sven, and everyone else.

Finally, I would like to thank two very important people who mean a great deal to me. Florence, my godchild. Even though you are only six months old, I am very proud of you and so happy that you are here. Your smile and shining eyes were the ideal encouragement during the writing process to write one more page at a time. Alexander, your love and unconditional support in this Ph.D. process was the critical success factor. We have made many sacrifices for our careers to this day. I look up to your incredible intelligence, management skills, and all other talents. It was very nice to have you at my side during this process, even though a lot of free time went into it.

Thank you!

Annelies Geerts

Lievegem, November 2019 


\section{CONTENTS}

Chapter 1. Introduction 17

1. Innovation management research 18

2. Focus of the dissertation 19

3. Dissertation outline 21

4. Methodology 23

5. References 24

Chapter 2. Achieving a balance between exploration and exploitation 27

$\begin{array}{ll}\text { Abstract } & 28\end{array}$

1. Introduction $\quad 29$

2. Theoretical background and hypotheses 31

2.1 Simultaneous, sequential and firm performance 31

2.1.1 Simultaneous exploration and exploitation $\quad 32$

2.1.2 Sequential exploration and exploitation $\quad 32$

2.2 Service firms versus manufacturing firms 33

3. Methods 34

3.1 Sample and data collection $\quad 34$

3.1.1 Exploratory cases $\quad 34$

3.1.2 CIS and Bel-first data $\quad 35$

$\begin{array}{ll}3.2 & \text { Dependent variable } \\ 3.36\end{array}$

$\begin{array}{ll}3.3 & \text { Independent variable } \\ 3.48\end{array}$

$\begin{array}{lll}3.4 & \text { Control variables } & 38\end{array}$

$\begin{array}{lll}3.5 & \text { Data analysis } & 39\end{array}$

4. Results 40

4.1 Exploring how service firms achieve a balance between exploration and exploitation $\quad 41$

4.2 Manufacturing and service firms and their actual innovation behavior $\quad 42$

4.3 Actual innovation behavior over time and firm performance 43

5. Discussion and conclusion $\quad 46$

5.1 Theoretical implications $\quad 46$

$\begin{array}{lll}5.2 & \text { Managerial implications } & 47\end{array}$

5.3 Limitations and avenues for future research 47

6. References 49

Appendix 1: Industry frequencies 53

Appendix 2: Contingency tables actual innovation behavior $\quad 54$

Appendix 3: Alternative hierarchical regression models 55 
Chapter 3. Does spatial ambidexterity pay off? On the benefits of geographic proximity between technology exploitation and exploration 59

$\begin{array}{ll}\text { Abstract } & 60\end{array}$

$\begin{array}{ll}\text { 1. Introduction } & 61\end{array}$

2. Background literature and hypothesis $\quad 62$

3. Methodology and data 65

3.1 Sample and data collection $\quad 65$

$\begin{array}{lll}3.2 & \text { Dependent variable } & 67\end{array}$

$\begin{array}{lll}3.3 & \text { Spatial ambidexterity } & 67\end{array}$

$\begin{array}{lll}3.4 & \text { Control variables } & 68\end{array}$

$\begin{array}{ll}\text { 4. Empirical results } & 70\end{array}$

$\begin{array}{ll}\text { 5. Conclusion and discussion } & 73\end{array}$

$\begin{array}{lll}5.1 & \text { Theoretical implications } & 73\end{array}$

$\begin{array}{ll}\text { 5.2 Managerial implications } & 74\end{array}$

$\begin{array}{lll}5.3 & \text { Limitations and avenues for future research } & 74\end{array}$

6. References 76

Chapter 4. Does market leadership require technological leadership in emerging markets? $\quad 81$

$\begin{array}{ll}\text { Abstract } & 82\end{array}$

1. Introduction 83

2. Theoretical background $\quad 84$

2.1 Market leadership $\quad 84$

2.2 Technological leadership $\quad 85$

2.3 Exploration, exploitation and the importance of a balanced portfolio 86

3. Methods 87

$\begin{array}{lll}3.1 & \text { Research setting and sample } & 87\end{array}$

$\begin{array}{ll}3.2 & \text { Data and method } \\ 3.3 & 89\end{array}$

$\begin{array}{lll}3.3 & \text { Variables } & 90\end{array}$

4. Results 92

4.1 Market leadership and technological leadership $\quad 92$

4.2 Market leadership and balancing technological exploration and exploitation 99

4.3 Market leadership and novelty in core technology development $\quad 100$

$\begin{array}{ll}\text { 5. Conclusion and discussion } & 101\end{array}$

$\begin{array}{lll}5.1 & \text { Summary and discussion of main findings } & 101\end{array}$

$\begin{array}{lll}5.2 & \text { Research implications } & 103\end{array}$

$\begin{array}{lll}5.3 \text { Managerial implications } & 103\end{array}$

$\begin{array}{ll}\text { 5.4 Limitations and directions for future research } & 104\end{array}$

$\begin{array}{ll}\text { 6. References } & 105\end{array}$

$\begin{array}{ll}\text { Appendix 1: History of digital data transport } & 108\end{array}$ 
1. Introduction 113

2. Research method 115

$\begin{array}{lll}2.1 & \text { Research setting and design } & 115\end{array}$

$\begin{array}{ll}2.2 & \text { Data collection and analysis } \\ \end{array}$

3. The ADSL innovation journeys of Alcatel and Ericsson 117

4. Identifying the critical components of an effective innovation journey 130

$\begin{array}{lll}4.1 & \text { Organizational design } & 130\end{array}$

4.2 People and roles 131

$\begin{array}{lll}4.3 & \text { Enacting resources } & 132\end{array}$

4.4 Operational flexibility 134

$\begin{array}{lll}4.5 & \text { Capabilities } & 135\end{array}$

5. Discussion and conclusion 137

$\begin{array}{lll}5.1 & \text { Theoretical implications } & 137\end{array}$

$\begin{array}{ll}\text { 5.2 Managerial implications } & 138\end{array}$

$\begin{array}{lll}5.3 & \text { Limitations and directions for future research } & 139\end{array}$

6. References 141

Chapter 6. Conclusion 145

1. Timing 146

2. Location 147

3. Technology 147

$\begin{array}{lll}\text { 4. Path } & 147\end{array}$

5. Contributions and implications 148

$\begin{array}{lll}5.1 & \text { Theory } & 149\end{array}$

$\begin{array}{lll}5.2 & \text { Practice } & 149\end{array}$

6. Limitations and directions for future research 150

7. References 152 


\section{LIST OF FIGURES}

Figure 1-1 Schematic overview of the dissertation 5

Figure 2-1 Computation of actual innovation behavior constructs 26

Figure 4-1 Total number of ADSL patents in relation to ADSL market share 99

Figure 4-2 Total number of citation-weighted ADSL patents in relation 100

to ADSL market share

Figure 4-3 Total number of electrical engineering patents in relation 102

to ADSL market share

Figure 4-4 Degree of balanced portfolio in electrical engineering patents 105 in relation to ADSL market share

Figure 5-1 ADSL, VDSL, FWBB and HFC European market share distribution of 124

Figure 5-2 Overview of the critical events in the ADSL innovation trajectory at Alcatel 142

Figure 5-3 Overview of the critical events in the ADSL innovation trajectory at Ericsson 143

Figure 5-4 Process models of innovation at Alcatel and Ericsson: the ADSL technology 144

Figure 5-5 Key time periods in an innovation journey and their factors 157

Figure 5-6 Components of an effective innovation journey 159 


\section{LIST OF TABLES}

Table 2-1 Cases and interviews per cases $\quad 23$

Table 2-2 Actual innovation behavior frequencies $\quad 27$

Table 2-3 Evidence from interview data case 1 32

Table 2-4 Evidence from interview data cases 2 and $3 \quad 32$

Table 2-5 Crosstabulation industry * actual innovation 34

Table 2-6 Crosstabulation industry * actual innovation behavior $\quad 35$

Table 2-7 Descriptive statistics 36

Table 2-8 Correlations 37

Table 2-9 Summary of hierarchical regression analysis for firm performance 38

Table 2-10 Industry frequencies based on technology and knowledge intensity 49

Table 2-11 Industry frequencies following the broad structure of NACE Rev. $1.1 \quad 49$

Table 2-12 Crosstabulation industry * actual innovation 50

Table 2-13 Crosstabulation industry * actual innovation behavior 50

Table 2-14 Summary of hierarchical regression analyses for firm performance 51

Table 2-15 Summary of hierarchical regression analyses for firm performance 52

Table 2-16 Summary of hierarchical regression analyses for firm performance 53

Table 2-17 Summary of hierarchical regression analyses for firm performance 54

Table 3-1 Sample firm distribution by industry and region of origin 63

$\begin{array}{lll}\text { Table 3-2 Descriptive statistics and correlations } & 69\end{array}$

Table 3-3 Results of negative binomial fixed effects panel data analysis $\quad 70$

Table 4-1 Descriptive statistics and correlations 96

Table 4-2 Ranking market share ADSL ports $\quad 97$

Table 4-3 Results of one-way between-subjects analysis of covariance of a firm's 101 activities in the core technology and market share

Table 4-4 Results of one-way between-subjects analysis of covariance of a firm's 103 activities in complementary technologies and market share

Table 4-5 Results of one-way between-subjects analysis of covariance of a firm's 106 exploratory and exploitative activities in complementary technologies and market share

Table 4-6 Results of one-way between-subjects analysis of covariance of a firm's 107 novelty in the core technology and market share

Table 4-7 A brief history of digital data transport towards ADSL for Internet access 


\section{Chapter 1}

\section{Introduction}


The operator of the largest container terminals in the port of Antwerp, DP World Antwerp, has been focusing on innovation for several years. "Those who do not innovate, risk being left behind on the market" (DP World Antwerp, 2018, para. 4). DP World Antwerp aims to increase its turnover with smart technological interventions, applications and additions. However, as the innovation manager of the firm explains, "technology misses its goal without strategic vision" and “innovation does not work without a long term vision" (DP World Antwerp, 2018, para. 1).

There is no doubt, firms acknowledge the importance of innovation for survival and growth. They spend up to $25 \%$ of their revenue on research and development (R\&D) and R\&D spending continues to increase in all regions and nearly all industries (Jaruzelski, Chwalik, \& Goehle, 2018). Unfortunately, innovation excellence cannot just be bought by spending more dollars on R\&D. In 2019, the Web of Science exhibits more than 50.000 scientific articles about innovation management. Amazon sells more than 20.000 books on innovation management. Despite the enormous amounts of money involved and a rich source of managerial literature that asks firms to invest in innovation and promises success in return, firms continue to struggle in capturing value from their innovation efforts. Innovation remains a difficult and often frustrating task for many of them.

\section{Innovation management research}

In a world of fierce competition and relentless change, incumbent firms are more than ever forced to think about how to achieve sustainable high performance. Since Schumpeter's (1934) seminal work on economic development, innovation is considered as one of the most important explanatory elements for long-term growth and firm survival. However, organizing for innovation does not present itself as a straightforward exercise. Innovation requires strategy. However, firms often tend to overlook the importance of aligning their innovation activities with their business strategies. The lack of an innovation strategy results in applying acclaimed best practices without considering the firm's particular innovation system (Pisano, 2015).

Firms need to exploit the present and explore the future. As such, the design and implementation of a sound innovation strategy encompasses multiple objectives. Whereas multiple definitions exist, an innovation strategy can be defined as the sum of strategic choices about to what extent, and how, a firm attempts to use innovation to pursue its business strategy.

An important aspect of a firm's innovation strategy is how it intends to balance its exploitation and exploration activities in order to be effective in the short run and to survive and prosper in the long run (e.g. Gupta, Smith, \& Shalley, 2006; Luger, Raisch, \& Schimmer, 2018; March, 1991). This balancing act is referred to as ambidexterity, a concept that gained a lot of scientific interest during the past decade. Organizational ambidexterity is defined as:

The ability of an organization to both exploit and explore - to compete in mature technologies and markets where efficiency, control and incremental improvement are prized and to also compete in new technologies and markets where flexibility, autonomy, and experimentation are needed (O’Reilly \& Tushman, 2013, p. 324). 
Firms trying to achieve both exploitation and exploration are being confronted with many, often opposing demands, imposing upon these organizations the challenge of reconciliation (Andriopoulos \& Lewis, 2010; Raisch \& Zimmermann, 2017). Perspectives and concepts developed on how to arrive at a reconciliation of exploitation and exploration within one and the same firm differ considerably. When reviewing the literature, different approaches can be delineated. Some studies pay particular attention to the scope of the technological activities of the firm and argue that relatedness and/or complementarities are crucial to reconcile both activities effectively (e.g. Cohen \& Tripsas, 2018; Markides \& Williamson, 1994; Tripsas, 1997). Other studies put a strong emphasis on the choice and elaboration of appropriate organizational design arrangements in which both types of activities become embedded (e.g. Brown \& Eisenhardt, 1997; Christensen \& Bower, 1996; Gibson \& Birkinshaw, 2004). Yet other research focuses on the people aspect such as the role of top management teams in facilitating the combination of exploration and exploitation (e.g. Jansen, Vera, \& Crossan, 2009; Koryak, Lockett, Hayton, Nicolaou, \& Mole, 2018; Lubatkin, Simsek, Ling, \& Veiga, 2006).

While the literature suggests various approaches and shows that exploration and exploitation as well as an innovation strategy are important, there remains a lot to discover for practitioners, especially with respect to how to organize for ambidexterity and how to deal with the conflicting demands.

\section{Focus of the dissertation}

How can incumbent firms effectively pursue their innovation strategy and journey by making the right choices in terms of time, location, technology and path?

This dissertation focuses on effective innovation strategies for incumbent firms or innovation strategies that pay off. How can incumbent firms reconcile exploration and exploitation as part of their innovation strategy? For example, should they invest in both activities simultaneously or can they first invest in one activity and then in the other, i.e. sequentially? Another question is where these activities should take place? Should exploration and exploitation take place in spatial proximity such that exploration and exploitation activities occur close to each other in terms of geographical distance? Or should firms spread their exploration and exploitation activities around the globe where exploration takes place in one region and exploitation in another? Lastly, which other factors play a crucial role for effectively pursuing innovation within incumbents? How decisive is technology in terms of technology leadership and a firm's technological portfolio? And what about the innovation journey from idea generation until introduction on the market? The innovation trajectories of incumbent firms occur in a very different firm-level context compared to innovation trajectories of new entrants. Traditionally, the literature mainly focused on the drawbacks of being an incumbent firm, making these firms vulnerable for innovation and potential displacement by newcomers (Abernathy \& Utterback, 1978; Christensen, 1997). Yet, both practice and more recent studies show that incumbents also possess particular advantages over new entrants (Fuentelsaz, Garrido, \& Maicas, 2015; Rothaermel \& Hill, 2005). 
This dissertation entails four studies that focus on different aspects of firm's innovation strategies. First, we apply a multilevel approach. Chapters two and three focus on the firm and its overall innovation behavior, chapters four and five focus on a particular innovation within the firm. These different views, i.e. broad and narrow or general and detailed, enable a comprehensive and thorough analysis concerning effective innovation strategies. Besides, we study firm strategies and practices in its geographical and industry context. Second, we look at four perspectives on effective innovation strategies: timing, location, technology and path to obtain in-depth insights into the complexity of managing and executing a firm's innovation strategy.

The relationship between these four perspectives on effective innovation strategies and the chapters of this dissertation is depicted in figure 1-1. The figure illustrates timing, location, technology and path as perspectives on effective innovation strategies.

Chapter two examines balancing exploitation and exploration through a simultaneous or sequential focus, defined as simultaneous and sequential ambidexterity. Chapter three adds a geographical dimension to the ambidexterity framework. In this chapter, the concept of spatial ambidexterity is developed. Chapter four studies the relationship between technological leadership and market leadership. Chapter five examines in-depth the process of effectively pursuing innovation from idea to market.

While the chapters focus on the content of each perspective, the reciprocal arrows show the interrelatedness between all of them. A firm's simultaneous or sequential exploration and exploitation occurs in spatial proximity or at a distance. But location also relates to timing as the choice of location might facilitate a simultaneous or sequential approach in exploration and exploitation activities. For most firms, technology plays an important role in innovation. Technological activity of an exploratory and exploitative nature takes place in certain locations while the efforts done at the locations result in technological development. Finally, each innovation strategy is enacted through one or more innovation paths or journeys. Technology has a central position in a firm's innovation path from idea to market, as is also the case with timing of the innovation activities. In turn, an innovation path influences timing and technology. Overall, the four perspectives are strongly connected to each other and all determine the effectiveness of an innovation strategy. 
Figure 1-1: Schematic overview of the dissertation

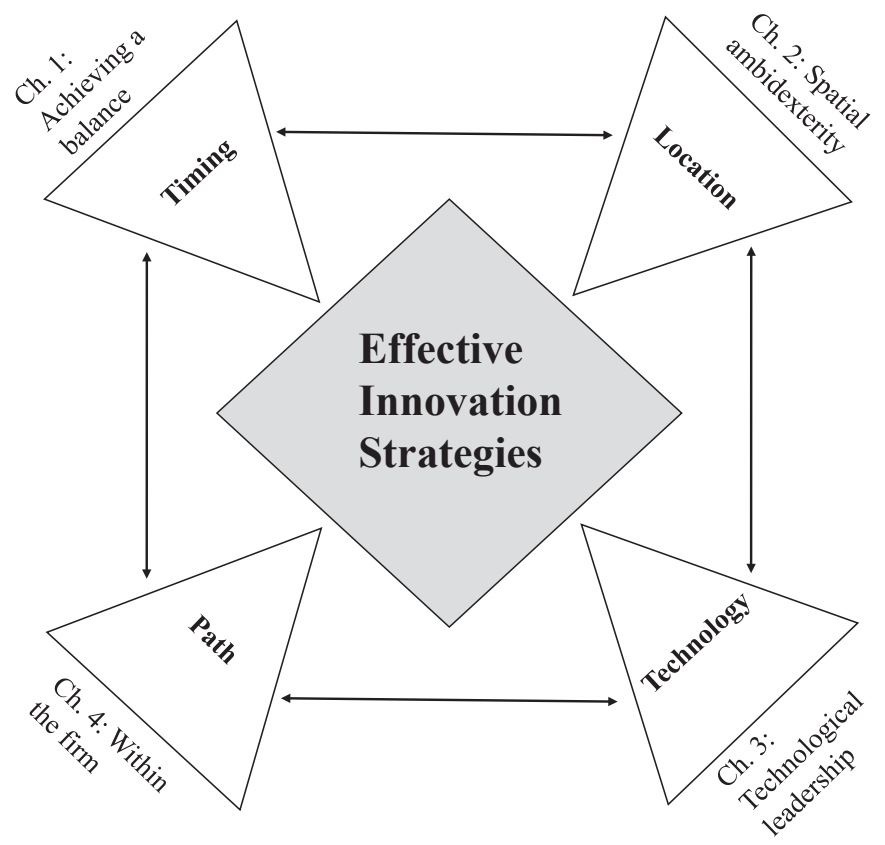

\section{Dissertation outline}

Chapter two, "achieving a balance between exploration and exploitation", questions whether a simultaneous and sequential organization of both activities are equally viable mechanisms. Whereas the simultaneous pursuit of exploration and exploitation is frequently seen as the solution to be successful, others concluded that exploration and exploitation can also be achieved in a sequential way. Scholars suggest that both mechanisms are evenly applicable for balancing exploration and exploitation (Mathias, McKenny, \& Crook, 2018). However, the literature remains relatively silent about potential differences in the performance consequences, and the conditions under which one model would be prevalent over the other. Relying on longitudinal data of the Belgian Community Innovation Survey (CIS4 and CIS5) and the financial bel-first database, this chapter examines 693 service and manufacturing firms and their effective innovation behavior over a period of five years (2002-2006).

This chapter contributes to the general research stream of exploration-exploitation and ambidexterity within the innovation management and strategy literature. In contrast to most prior empirical research, we differentiate between simultaneous and sequential ambidexterity, over a period of five years. We add to our understanding whether there is a difference in balancing innovation behavior between manufacturing and service firms. This study provides insight into the prevalence of strategies that firms within different industries enact to balance exploration and exploitation. 
Chapter three, "does spatial ambidexterity pay off?", considers the increasing internationalization of innovation activities by multinational firms. The spatial aspect of the organization of innovation has received recent ample attention in the literature (e.g. Belderbos, Lokshin, \& Sadowski, 2015; Lahiri, 2010). However, the consequences for ambidexterity have not been examined. Prior research has ignored a geographical dimension in explaining the ambidexterity-performance relationship.

In this chapter, the concept of 'spatial ambidexterity' is developed and validated. Spatial ambidexterity refers to the extent to which firms jointly pursue technology exploration and exploitation in spatial proximity. We argue that both activities benefit from proximity as firms will increase their ability to enact cross-fertilization opportunities and synergies between exploratory and exploitative technological activities. This study relies on a panel dataset (1995-2003) of the technological activities of 156 large European, U.S., and Japanese firms that are active in five R\&Dintensive manufacturing industries. Patent data are used to construct indicators of technology exploration and exploitation and to derive information on the locations where the activities occur.

This chapter contributes to the literature on organizing for organizational ambidexterity by arguing that the potential to coordinate between exploration and exploitation activities also depends on the spatial configuration of firm's technology exploration and exploitation activities.

Chapter four, "does market leadership require technological leadership?", explores the relation between market leadership and technological leadership in an emerging high-tech market. While it is often assumed that capturing market share requires/builds on technological innovation, the relationship between market leadership and technological leadership has not been widely explored. The link between ambidexterity and competing in new technologies and markets has mainly been described in the context of transitions and extensions of existing markets (Tushman \& Oreilly, 1996). While consensus exists about the necessity for firms to engage in both R\&D-based exploration and exploitation activities, little is known about whether a balanced technological portfolio is related to market leadership in an emerging market.

This chapter questions to what extent market leadership requires technological leadership and if technological activities enable firms to become market leaders in an emerging high-tech market.

The study focuses on the Asymmetric Digital Subscriber Loop (ADSL) technology market that emerged at the end of the 1990s. An exploratory analysis of patent (1990-2003) and market (19982003) data from 17 telecommunication equipment firms that composed the emerging global ADSL market, reveals intriguing insights that lead to the in-depth comparative case study in chapter five.

This chapter contributes to our knowledge about the role of technology in market leadership and the relevance of combining exploration and exploitation efforts in an emerging high-tech market.

Chapter five, "how Alcatel outperformed Ericsson in its ADSL innovation journey" builds on the previous chapter and examines through a comparative case study design how Alcatel made a success story from ADSL while Ericsson experienced a failure in this new ADSL market, despite its innovation efforts. Although process thinking is an emergent trend in organization studies, few scholars apply a process perspective in studying innovation (Janssen, Stoopendaal, 
\& Putters, 2015; Van de Ven, 1999). This chapter offers a close examination of the process of an innovation trajectory within an incumbent firm. It explains how Alcatel and Ericsson were exploring and enacting opportunity alongside their current business. How can incumbent firms effectively pursue innovation? How do top management teams and project managers influence the innovation trajectory when a new opportunity arises? What are the important decision moments and decisions?

This chapter applies a process view on organizing for innovation and combines the study of organization structure, resources and individuals. The longitudinal comparative case study design encompasses the period from the early 1990s until stages of technological maturity were reached in 2003.

This chapter contributes to our understanding about how incumbent firms can effectively organize for innovation, given the dynamic nature of innovation trajectories. Moreover, this study adds to our knowledge about what makes firms and their teams come to certain decisions and how this results in effectively pursuing innovation of a more novel nature within incumbents. Finally, this chapter illuminates the importance of applying a process perspective in studying innovation.

\section{Methodology}

“... mathematics is just the visible tip of the iceberg of economics and the rest of the problem is much softer, more mystical, and does not offer itself easily to deterministic model-building" (Sedlacek, 2011, p. 324).

A mixed methodological approach can offer valuable insights and advances research in innovation management and strategy (Bettis, Gambardella, Helfat, \& Mitchell, 2014). This dissertation relies on multiple data sources and different methodological approaches of a quantitative and qualitative nature. Some research questions in this dissertation are answered by econometric techniques while other research questions involve a qualitative method that allows for a more in-depth and nuanced understanding of empirical phenomena.

Examining the four perspectives on innovation strategies (timing, location, technology and path) requires the application of more than one methodological approach. In order to identify effective innovation strategies in terms of financial, technological and market performance, longitudinal datasets are statistically analyzed in different ways (see Chapters 2, 3 and 4). Although these analyses provide valuable insights about the strategies that firms can enact to balance exploration and exploitation, a more thorough understanding is possible through case study research (see Chapters 2 and 5). In this respect, chapter five examines the innovation journeys of two competing firms through a detailed comparative case study design. 


\section{References}

Abernathy, W. J., \& Utterback, J. M. (1978). Patterns of Industrial Innovation. Technology Review, 80(7), 40-47. Andriopoulos, C., \& Lewis, M. W. (2010). Managing Innovation Paradoxes: Ambidexterity Lessons from Leading Product Design Companies. Long Range Planning, 43(1), 104-122. doi: 10.1016/j.lrp.2009.08.003

Belderbos, R., Lokshin, B., \& Sadowski, B. (2015). The returns to foreign R\&D. Journal of International Business Studies, 46(4), 491-504. doi: 10.1057/jibs.2014.63

Bettis, R., Gambardella, A., Helfat, C., \& Mitchell, W. (2014). Quantitative empirical analysis in strategic management. Strategic Management Journal, 35(7), 949-953. doi: 10.1002/smj.2278

Brown, S. L., \& Eisenhardt, K. M. (1997). The art of continuous change: Linking complexity theory and timepaced evolution in relentlessly shifting organizations. Administrative Science Quarterly, 42(1), 1-34. doi: $10.2307 / 2393807$

Christensen, C. M. (1997). The innovator's dilemma: When new technologies cause great firms to fail. Boston: Harvard Business School Presss.

Christensen, C. M., \& Bower, J. L. (1996). Customer power, strategic investment, and the failure of leading firms. Strategic Management Journal, 17(3), 197-218. doi: 10.1002/(sici)1097-0266(199603)17:3<197::aidsmj804>3.3.co;2-1

Cohen, S. L., \& Tripsas, M. (2018). Managing technological transitions by building bridges. Academy of Management Journal, 61(6), 2319-2342. doi: 10.5465/amj.2015.0690

DP World Antwerp. (2018). Innovatie werkt niet zonder langetermijnvisie. https://www.tijd.be/partner/ dpworldantwerp/investeren-in-de-toekomst/Innovatie-werkt-niet-zonder-langetermijnvisie/10074364

Fuentelsaz, L., Garrido, E., \& Maicas, J. P. (2015). Incumbents, technological change and institutions: How the value of complementary resources varies across markets. Strategic Management Journal, 36(12), 17781801. doi: 10.1002/smj.2319

Gibson, C. B., \& Birkinshaw, J. (2004). The antecedents, consequences, and mediating role of organizational ambidexterity. Academy of Management Journal, 47(2), 209-226. doi: 10.2307/20159573

Gupta, A. K., Smith, K. G., \& Shalley, C. E. (2006). The interplay between exploration and exploitation. Academy of Management Journal, 49(4), 693-706. doi: 10.2307/20159793

Jansen, J. J. P., Vera, D., \& Crossan, M. (2009). Strategic leadership for exploration and exploitation: The moderating role of environmental dynamism. Leadership Quarterly, 20(1), 5-18. doi: 10.1016/j.leaqua.2008.11.008

Janssen, M., Stoopendaal, A. M. V., \& Putters, K. (2015). Situated novelty: Introducing a process perspective on the study of innovation. Research Policy, 44(10), 1974-1984. doi: 10.1016/j.respol.2015.06.008

Jaruzelski, B., Chwalik, R., \& Goehle, D. (2018). The global innnovation 1000 - What the Top Innovators Get Right. Strategy+Business, 93(Winter 2018), 1-26.

Koryak, O., Lockett, A., Hayton, J., Nicolaou, N., \& Mole, K. (2018). Disentangling the antecedents of ambidexterity: Exploration and exploitation. Research Policy, 47(2), 413-427. doi: 10.1016/j.respol.2017.12.003

Lahiri, N. (2010). Geographic distribution of R\&D activity: How does it affect innovation output? Academy of Management Journal, 53(5), 1194-1209. doi: 10.5465/amj.2010.54533233

Lubatkin, M. H., Simsek, Z., Ling, Y., \& Veiga, J. F. (2006). Ambidexterity and performance in small- to mediumsized firms: The pivotal role of top management team behavioral integration. Journal of Management, 32(5), 646-672. doi: 10.1177/0149206306290712

Luger, J., Raisch, S., \& Schimmer, M. (2018). Dynamic Balancing of Exploration and Exploitation: The Contingent Benefits of Ambidexterity. Organization Science, 29(3), 449-470. doi: 10.1287/orsc.2017.1189

March, J. G. (1991). Exploration and exploitation in organizational learning. Organization Science, 2(1), 71-87. doi: 10.1287/orsc.2.1.71

Markides, C. C., \& Williamson, P. J. (1994). Related diversification, core competences and corporate performance. Strategic Management Journal, 15, 149-165.

Mathias, B. D., McKenny, A. F., \& Crook, T. R. (2018). Managing the tensions between exploration and exploitation: The role of time. Strategic Entrepreneurship Journal, 12(3), 316-334. doi: 10.1002/sej.1287 
O’Reilly, C. A., \& Tushman, M. L. (2013). Organizational ambidexterity: Past, present, and future. Academy of Management Perspectives, 27(4), 324-338. doi: 10.5465/amp.2013.0025

Pisano, G. P. (2015). You need an innovation strategy. Harvard Business Review, 93(6), 44-54.

Raisch, S., \& Zimmermann, A. (2017). Pathways to Ambidexterity: A Process Perspective on the ExplorationExploitation paradox The Oxford Handbook of Organizational Paradox (1 ed., pp. 315-332). Oxford: Oxford University Press.

Rothaermel, F. T., \& Hill, C. W. L. (2005). Technological discontinuities and complementary assets: A longitudinal study of industry and firm performance. Organization Science, 16(1), 52-70. doi: 10.1287/orsc.1040.0100

Schumpeter, J. A. (1934). The theory of economic development. Cambridge, MA: Harvard University Press.

Sedlacek, T. (2011). Economics of Good and Evil: The quest for economic meaning from Gilgamesh to Wall Street. New York: Oxford University Press.

Tripsas, M. (1997). Unraveling the process of creative destruction: Complementary assets and incumbent survival in the typesetter industry. Strategic Management Journal, 18, 119-142. doi: 10.1002/(sici)10970266(199707)18:1+<119::aid-smj921>3.3.co;2-s

Tushman, M. L., \& Oreilly, C. A. (1996). Ambidextrous organizations: Managing evolutionary and revolutionary change. California Management Review, 38(4), 8-\&. doi: 10.2307/41165852

Van de Ven, A. H. (1999). The Innovation Journey. Oxford, UK: Oxford University Press. 


\section{Chapter 2}

\section{Achieving a balance between exploration and exploitation'}

1 This chapter is based on: Geerts, A., Blindenbach-Driessen, F. \& Gemmel, P. 2010. Achieving a Balance between Exploration and Exploitation in Service Firms: A Longitudinal Study. In Leslie A. Toombs (Ed.), Best Paper Proceedings of the Seventieth Annual Meeting of the Academy of Management (CD), ISSN 15438643. 


\section{Abstract}

'Ambidexterity' is typically seen as the solution to be successful through balancing exploration and exploitation simultaneously. Some scholars have claimed that a balance in exploration and exploitation can also be achieved in a sequential way, characterized by cycling through periods of exploration and exploitation. The existing literature is relatively silent on the question whether simultaneous and sequential ambidexterity are equally viable mechanisms, or what would be the conditions under which one model would be prevalent over the other. Prior studies provide different answers to the question whether ambidexterity leads to better firm performance. Little is also known about the link between different economic industries and balancing exploration and exploitation; while many studies have been published on the innovation behavior of manufacturing firms, much less is known about the innovation behavior of service firms. How prevalent are different forms of ambidexterity in service firms? The purpose of this chapter is to investigate whether service firms differ from manufacturing firms in the way a balance between exploration and exploitation is achieved, and to what extent different ways of organizing for innovation over time relate to firm performance. First, a brief exploratory case study is carried out at three service firms. Second, drawing on data of the Belgian Community Innovation Survey and the bel-first database, we examine 693 firms and their actual innovation behavior over a period of five years (2002-2006). Our interview data suggest that service firms' choice for different forms of ambidexterity depends on managerial judgement, available resources and environmental circumstances. The results from our quantitative analyses suggest that there is a significant difference in innovation behavior between service firms and manufacturing firms, whereby manufacturing firms are more likely to use the simultaneous ambidexterity model and service firms the sequential ambidexterity model. There seems to be no association between a firm's actual innovation behavior and firm performance within the observed time frame. 


\section{Introduction}

The service industry has surpassed manufacturing and agriculture to become the fastest-growing and most dominant industry in each of the world's key economies and almost all countries (The World Bank Group, 2019a). Services now account for more than 70\% of employment and GDP in most developed countries (International Labour Organization, 2019; The World Bank Group, 2019b).

Since Schumpeter's theory of economic development (Schumpeter, 1934), innovation has taken shape as one of the most powerful explanatory elements for long-term growth (Ahlstrom, 2010; Spescha \& Woerter, 2019). From the ambidexterity literature it is known that not innovation per se, but the balance between exploratory and exploitative types of innovation enables firms to be effective (survive) in the medium/long run and to achieve superior performance (Benner \& Tushman, 2003; He \& Wong, 2004; Raisch \& Zimmermann, 2017; Tushman \& O’Reilly, 1996). Balancing exploration and exploitation, is far from easy as both often draw from the same resources, yet ask for a very different strategic mindset (Koryak, Lockett, Hayton, Nicolaou, \& Mole, 2018; March, 1991). The concept of ambidexterity has increasingly been subject of research in leading management journals during the past decade (Birkinshaw \& Gupta, 2013; Luger, Raisch, \& Schimmer, 2018). Previous studies of ambidexterity have focused on the concept from for example a technological or a resource point of view and examined how it contributes to firm performance, leading to different conclusions (Rothaermel \& Alexandre, 2009; Wassmer, Li, \& Madhok, 2017). We know little, however, about the link between different economic industries and balancing exploration and exploitation. Especially research on ambidexterity in service firms is almost nonexistent (e.g. Blindenbach-Driessen \& van den Ende, 2014; Gabler, Ogilvie, Rapp, \& Bachrach, 2017).

For the service industry, innovation is likely as important as it is for the manufacturing industry, yet there is still ambiguity whether innovation in service firms should be managed similarly to innovation in manufacturing firms. Some scholars argue that the innovation theories initially developed for manufacturing firms do not apply for service firms (Ettlie \& Rosenthal, 2011; Hipp \& Grupp, 2005). Others find no substantial differences between the two sectors (Leiponen \& Drejer, 2007). Damanpour, Walker and Avellaneda (2009) state that the logic of innovation development in manufacturing firms may not be used to explain the generation of innovations in service firms. Innovations in the manufacturing sector often follow a technological trajectory, whereas this is not the case for the service sector (Aboal \& Tacsir, 2018; Damanpour et al., 2009).

One of the arguments used in the ambidexterity literature is the need to invest in new technologies and capabilities (Jansen, Van den Bosch, \& Volberda, 2005), as it will be difficult to catch up later, once the technology breaks through. Can service firms wait with investing in new capabilities and jump in later, as the technological component is less relevant? Or do service firms also need to invest upfront in new service areas to be prepared in the future, as it takes time to train personnel? Even, if service firms do not need to invest in new service areas upfront, because the technology can be easily absorbed at a later stage, will they be able to change in the light of 
new service areas? The ability to change, often referred to as a firm's dynamic capabilities, enables a firm to react to its environment (Teece, Pisano, \& Shuen, 1997). If service firms can wait till opportunities are there, will they be able to rely on dynamic capabilities when needed?

Whereas 'ambidexterity' is frequently seen as the solution to be successful through balancing exploration and exploitation simultaneously (Benner \& Tushman, 2003; He \& Wong, 2004; Jansen, Simsek, \& Cao, 2012), other scholars concluded that exploration and exploitation can also be achieved in a sequential way (Gersick, 1991; Mudambi \& Swift, 2011; Venkatraman, Lee, \& Iyer, 2007). The sequential mechanism allows a firm to cycle through periods of exploration and exploitation instead of simultaneously exploring and exploiting (Gupta, Smith, \& Shalley, 2006). Scholars suggest that both approaches are evenly applicable for balancing exploration and exploitation (Mathias, McKenny, \& Crook, 2018). The existing literature is relatively silent about potential differences in performance outcome, and the conditions under which one model would be prevalent over the other.

The purpose of this chapter is two-fold. First, this study questions to what extent service firms differ from manufacturing firms in the way a balance between exploration and exploitation is achieved. Second, this paper examines to what extent different ways of organizing for innovation impact firm performance.

Through a brief exploratory case study in three service firms, we first gain insights in how important ambidexterity is for service firms, how they achieve a balance between exploration and exploitation and what the drivers are. Drawing on survey data of 693 firms over a period of five years, we examine which mechanism manufacturing and service firms use to achieve a balance between exploration and exploitation. Next, we investigate how that impacts firm performance. ${ }^{2}$ We use data from the Belgian Community Innovation Survey (CIS) from 2002 to 2006. In addition, a firm performance database, Bel-first, is used to assess firm performance.

This study contributes to the general research stream that investigates the relationship between exploration and exploitation, and contributes to the service innovation management literature. Firstly, in contrast to most prior empirical research, we differentiate between simultaneous and sequential ambidexterity, over a period of five years. Secondly, we add to our understanding whether there is a difference in balancing innovation behavior between manufacturing and service firms. Is ambidexterity equally important for all types of firms, as suggested by the ambidexterity literature (He \& Wong, 2004; Luger et al., 2018), or do firms in some industries benefit from a more focused approached (Leiponen, 2012; Uotila, Maula, Keil, \& Zahra, 2009)? Prior research has found that within the software sector, the sequential model is a more significant predictor for firm growth compared to the simultaneous ambidexterity model (Venkatraman et al., 2007). The authors considered ambidexterity as a dynamic capability that is embodied in routines for exploration and exploitation over time. At the origin of the positive relationship between sequential ambidexterity and firm growth, are specific mechanisms that software firms

2 Actually organizing for innovation relates to the effective introduction of product and/or process innovations. 
use to mitigate problems of coordination uncertainty. However, their data did not reveal which mechanisms were adopted. Does this also apply to other types of service industries? Thirdly, it is acknowledged that firms across industries struggle with the challenges related to sustainable value creation (Kolluru \& Mukhopadhaya, 2017; Raisch, Birkinshaw, Probst, \& Tushman, 2009). This study provides insight into the prevalence of strategies that firms within different industries enact to balance exploration and exploitation.

\section{Theoretical background and hypotheses}

The term 'organizational ambidexterity' was used for the first time by Duncan (1976) and made 'popular' by Tushman and O'Reilly $(2004,2008,2011 ; 1996)$. The current interest in the concept resides in the pioneering article of March (1991), in which he proposes exploration and exploitation as different learning activities that require divided attention and resources from firms. Exploration implies organizational behavior characterized by search, discovery, experimentation, risk taking. Exploratory or radical innovations represent fundamental changes leading to a switch from existing products, methods or processes to completely new ones (de Brentani \& Reid, 2012; Garcia \& Calantone, 2002; Smith \& Tushman, 2005). The core of exploration is experimentation with new alternatives. Exploitation implies organizational activities characterized by refinement, choice, efficiency, selection and implementation. The essence of exploitation is the refinement and extension of existing competences, technologies, and paradigms (March, 1991). Exploitation refers to improvements of current products through innovation in the applied methods and processes that enable a company to operate more efficiently and deliver greater value to the customers (O'Reilly \& Tushman, 2004; Wojan, Crown, \& Rupasingha, 2018). March (1991) suggests that firms need to be aligned to both exploration and exploitation. Firms who exclusively focus on exploration will enhance the ability to renew its knowledge base, but it can result in experiencing high costs of experimentation without gaining many benefits. On the opposite, firms who concentrate solely on exploitation may enhance short-term performance, but are likely to find themselves trapped in suboptimal stable equilibria, not able to respond adequately to environmental changes.

Earlier studies often considered the trade-offs between exploration and exploitation as inconceivable (Ghemawat \& Costa, 1993; Miller \& Friesen, 1986). More recent research illuminates ambidextrous organizations that are able to simultaneously exploit existing competencies and explore new opportunities (Andriopoulos \& Lewis, 2010; Koryak et al., 2018; O’Reilly \& Tushman, 2011).

\subsection{Simultaneous, sequential and firm performance}

March's (1991) proposition that successful firms are ambidextrous resulted in an organizational research shift from trade-off to paradoxical thinking (Eisenhardt \& Martin, 2000; Lewis, 2000). Researchers have come to recognize the importance of balancing exploration and exploitation. The concept of ambidexterity has been used in various works, ranging from technological change 
to organization design (Birkinshaw \& Gupta, 2013; Garcia-Lillo, Ubeda-Garcia, \& Marco-Lajara, 2016). Although various definitions exist, there is a broad agreement that organizational (or structural) ambidexterity relates to the simultaneous pursuit of exploratory and exploitative activities within one and the same (consolidated) firm (Raisch \& Birkinshaw, 2008; Tushman \& O’Reilly, 1996; Uotila, 2018). In the light of the growing interest on ambidexterity, researchers increasingly began to question whether simultaneously exploring and exploiting is the only way to achieve a balance between both activities (Boumgarden, Nickerson, \& Zenger, 2012; Gupta et al., 2006; Uotila, 2018; Venkatraman et al., 2007).

\subsubsection{Simultaneous exploration and exploitation}

Following Jansen, Van den Bosch, and Volberda (2005), we define ambidexterity as the ability to pursue exploratory and exploitative innovations simultaneously. We name this 'simultaneous ambidexterity'. Tushman and O'Reilly (1996) suggest that firms able of simultaneously pursuing exploration and exploitation are more likely to achieve higher performance than firms focusing on one at the expense of the other. Firms who mainly engage in exploration will experience difficulties in estimating their returns a priori. It may take long time before performance benefits actually arise, if at all (Volberda \& Lewin, 2003). On the opposite, firms who principally concentrate on exploitation usually achieve returns that are proximate and predictable but not necessarily sustainable (Levinthal \& March, 1993). In addition, firms can benefit from cross-fertilization and synergies between their simultaneous exploration and exploitation efforts (Van Looy, Martens, \& Debackere, 2005). A firm's ability to be successful in the long run may thus be linked to the ability of being ambidextrous. Several empirical studies prove that simultaneous ambidexterity, i.e. simultaneously pursuing exploration and exploitation, results in higher performance levels (e.g. Gibson \& Birkinshaw, 2004; He \& Wong, 2004; Lubatkin, Simsek, Ling, \& Veiga, 2006). For example, He and Wong (2004) conclude that being able to simultaneously explore and exploit is positively associated with firm sales growth. Measuring a firm's objective to explore and exploit, Derbyshire (2014) finds in a large-scale study that ambidexterity has a positive effect on growth in sales turnover in manufacturing and scientific and technical services sectors.

However, other scholars conclude that simultaneous ambidexterity has no significant impact on firm performance of knowledge-intensive firms, measured in terms of profit growth, sales growth and market share growth (Vrontis, Thrassou, Santoro, \& Papa, 2017). Studying the software sector, Venkatraman, Lee and Iyer (2007) also did not find empirical evidence for a positive simultaneous ambidexterity-performance hypothesis.

In their meta-analysis of the organizational ambidexterity-performance relationship, Junni et al. (2013) find that positive and significant relationships are to a large extent moderated by contextual factors and methodological choices. Their study reveals that organizational ambidexterity is especially important for performance in nonmanufacturing industries.

\subsubsection{Sequential exploration and exploitation}

Scholars identified sequential ambidexterity as an alternative way to achieve a balance between 
exploration and exploitation (Boumgarden et al., 2012; Gupta et al., 2006; Siggelkow \& Levinthal, 2003; Uotila, 2018). It is defined as cycling through periods of exploration and exploitation (Gupta et al., 2006). Related to this view, the concept of 'punctuated equilibrium', time-spaced sequence of exploration and exploitation, is developed (Puranam, Singh, \& Zollo, 2006; Venkatraman et al., 2007).

Sequential ambidexterity might be beneficial for resource-constrained firms to balance exploration and exploitation as they can shift from one activity to the other instead of doing both simultaneously. The difficulty for firms that apply a sequential method is to know when to shift to exploration or exploitation (Hughes, 2018).

Contrary to the findings of for example Gibson \& Birkinshaw (2004), He \& Wong (2004) and Lubatkin et al. (2006), Venkatraman, Lee and Iyer (2007) did not found empirical evidence for a positive relationship between simultaneous ambidexterity and firm performance. Instead, they found that temporal cycling through periods of exploration and exploitation has a positive effect on firm performance. Relying on two in-depth case studies, Boumgarden et al. (2012) concluded that sequential ambidexterity, which they described as organizational vacillation, may result in higher long run performance than organizational ambidexterity.

In general, empirical evidence of the relationship between ambidexterity or punctuated equilibrium and performance remains limited and mixed (Junni et al., 2013; Mathias et al., 2018). One of the differences between these studies are the type of firms studied. Those who found positive relationships for simultaneous ambidexterity, mainly had manufacturing firms in their sample (e.g. He \& Wong, 2004), while for example Venkatraman et al. (2007) who looked at sequential ambidexterity had software and information technology firms in their sample .

Simultaneous and sequential ambidexterity involve a very different view of how exploration and exploitation are organized. Examining the effect of sequential ambidexterity is important, since not all firms are able or choose to pursue simultaneously exploration and exploitation (Siggelkow \& Levinthal, 2003; Uotila, 2018). According to Uotila (2018), much depends on the turbulence and complexity of the environment whether a sequential or simultaneous approach are sufficient to keep pace with the task environment. Except for the studies of Venkatraman et al. (2007) and Boumgarden et al. (2012), no direct empirical test of the impact of sequential ambidexterity on firm performance exists in the literature.

\subsection{Service firms versus manufacturing firms}

In order to compare the balancing behavior of exploration and exploitation between service and manufacturing firms, we use a generic definition for innovation: 'innovation is the implementation of a new or significantly improved product (good or service), or process, a new marketing method, or a new organizational method in business practices, workplace organization or external relations' (OECD, 2018).

Innovation has long been linked to technology driven product- and process innovations in the manufacturing industry. Originally, the majority of innovation studies have used the manufacturing industries as a reference, putting the service sector aside (Castellacci, 2008). 
However, in recent years, we have seen a gradual growth in the number of publications on innovation in service firms. Nowadays, the service sector is shedding its image of being mainly non-innovative or supplier driven. This is related to an alternative view of services being different innovators compared to manufacturers, or the perspective that innovations in services focus more on the 'softer' aspects of innovation based skills (Aboal \& Tacsir, 2018; Blindenbach-Driessen \& van den Ende, 2014).

The main differences between how manufacturing and service firms address innovation are the way they formalize the process, the way service firms test customer concepts and the combined role of managers and professionals in the innovation process (Ettlie \& Rosenthal, 2011). Sundbo and Gallouj (2000) define innovations in the service sector as more incremental innovations, based on small adjustments of procedures. Ettlie and Rosenthal (2011) define innovations in service firms as multidimensional processes, less technological compared with manufacturing but with more emphasis on the organizational aspect. A recent study of Aboal and Tacsir (2018) indicates that nontechnological innovations, i.e. organizational and marketing, contribute more to firm productivity in service firms than in the manufacturing sector. Service firms might not need to continuously invest in an exploratory type of innovation capabilities to keep up to date. This would enable service firms to explore on a more ad-hoc and opportunity bases, as suggested by the advocates of the punctuated equilibrium model (Gersick, 1991; Venkatraman et al., 2007).

Blindenbach-Driessen and van den Ende (2014) find that if innovations are of a less technological nature and close to practice, as is often the case within service firms, it might not be necessary to continuously invest in both exploration and exploitation. Economies of scale are usually less pronounced in service firms; simultaneity often jeopardizes scaling of a non-linear nature. Leiponen (2012) argues that service firms might not possess the managerial processes and capabilities to benefit from breadth in innovation objectives. Gabler et al. (2017) suggest that ambidexterity may have a dark side in the service industry. They argue that employees experience a role conflict when ambidextrous behavior is expected. It could be more beneficial for service firms to apply a punctuated equilibrium model.

Given the different findings of the benefits of simultaneous and sequential ambidexterity and the different nature of firms that were used in these studies, we will investigate whether there is indeed a difference in how service and manufacturing firms organize for ambidexterity and how this impacts firm performance.

\section{Methods}

\subsection{Sample and data collection}

\subsubsection{Exploratory cases}

We conducted interviews in three service firms to explore how important ambidexterity is and how service firms explore and exploit. We intended to contrast firms that represented different sectors in 
the service economy and hoped to find different approaches in balancing exploration and exploitation. Of the three firms investigated, two firms followed a sequential ambidexterity model and one firm pursued simultaneous ambidexterity. Table 2-1 presents short descriptions of the three cases (the names of the firms are not mentioned to ensure confidentiality) and information on the persons we interviewed for each case. Since the third case has a much larger firm size compared to the two other cases, we interviewed four managers instead of the CEO only.

Table 2-1: Cases and interviews per cases

\begin{tabular}{|c|c|c|c|c|c|}
\hline Case & Business description & Firm Age & \# Employees & $\begin{array}{l}\text { Innovation } \\
\text { behavior }\end{array}$ & Interviewees \\
\hline Travel agency & $\begin{array}{l}\text { Provides full-service } \\
\text { travels in three distinct } \\
\text { departments: holidays, } \\
\text { business and groups, } \\
\text { incentives }\end{array}$ & 35 years & 55 & $\begin{array}{l}\text { Simultaneous } \\
\text { ambidexterity }\end{array}$ & $\mathrm{CEO}$ \\
\hline $\begin{array}{l}\text { Study and } \\
\text { design office }\end{array}$ & $\begin{array}{l}\text { Provides study and design } \\
\text { work for industrial purposes }\end{array}$ & 20 years & 25 & $\begin{array}{l}\text { Sequential } \\
\text { ambidexterity }\end{array}$ & $\mathrm{CEO}$ \\
\hline Wholesaler & $\begin{array}{l}\text { Provides a wide range of } \\
\text { engineering parts together } \\
\text { with a range of technical and } \\
\text { logistical services }\end{array}$ & 53 years & 174 & $\begin{array}{l}\text { Sequential } \\
\text { ambidexterity }\end{array}$ & $\begin{array}{l}\text { CTO, Sales } \\
\text { manager, } \\
\text { Logistics } \\
\text { manager, } \\
\text { Business unit } \\
\text { manager }\end{array}$ \\
\hline
\end{tabular}

Interviews commonly took two hours, and were partially structured. The interview typically began with an invitation to describe the firm and its general attitude towards innovation. The interview generally covered five broad topics: (1) the innovation strategy, with a clear focus on explorative and exploitative behavior, (2) the employee and company culture, (3) market and customer orientation, (4) environmental uncertainty and (5) the decision and its rationale to opt for simultaneous versus sequential ambidexterity. These topics were questioned in detail and well-defined descriptions were given to innovation, exploration and exploitation. In every case, the respondents were encouraged to provide concrete examples of their points. For each interview, we made extensive handwritten notes. To reduce bias, we collected data from other sources as well. We monitored the web sites of each firm and collected information from business press. These sources enabled us to build stronger interpretations (Jick, 1979).

\subsubsection{CIS and Bel-first data}

The empirical setting in the quantitative part of this study is the manufacturing and service sector in Belgium. Our longitudinal approach consists of the Belgian Community Innovation Survey (CIS) data observed from 1st January 2002 until 31st December 2006, taken from CIS4 (20022004) and CIS5 (2004-2006). The CIS is coordinated by the statistical agency of the European Union, Eurostat, and executed by the member countries. The data were collected through a census sampling for large size firms (i.e. with 250 or more employees), and stratified random sampling for the other firms. Size and sector were used as stratification variables. The surveys were filled out by 
the chief executive officer or R\&D manager of each firm.

We have merged the data files of CIS4 and CIS5 to one separate data file based on the company's ID. Our sample consists of 693 firms who participated to both CIS4 and CIS5, representing 252 service firms and 441 manufacturing firms. Annual performance data of these firms, for the period 2001-2007, is provided by the Bel-first database. Bel-first is a public database that contains detailed financial firm data of Belgian firms. Due to missing values of the financial indicators and the elimination of outliers, the sample size was further restricted to 399 firms when examining the association between actual innovation behavior and firm performance.

\subsection{Dependent variable}

The quantitative study involves two types of analysis. First, we examine the prevalence of different types of innovation behavior by industry. The dependent variable is actual innovation behavior. Exploration versus exploitation in the business activities of the firms during 2002-2006 forms the foundation of our dependent variable in the first analysis. A diverse range of operationalizations has emerged for exploration and exploitation (Junni et al., 2013; O’Reilly \& Tushman, 2013). We base our operational definition of exploration and exploitation on O'Reilly and Tushman (2007), who describe exploration as encompassing search, discovery, autonomy, innovation, embracing variation and exploitation as capturing efficiency, increasing productivity, control, certainty and variance reduction. Following prior research (Blindenbach-Driessen \& van den Ende, 2014), exploration refers to introducing new or significantly improved products or services during the 2002-2006 period. This introduction can be new to the firm and/or new to the market. The value of the exploration variable is 1 (0) if the firm reports that (no) new or significantly improved products or services were introduced over the period 2002-2006. Exploitation captures introducing new or improved methods geared at the production process, the logistics or distribution, or supportive systems of either goods or services, during the 2002-2006 period. The exploitation variable has the value of 1 (0) if the firm reports that (no) such innovations were introduced. ${ }^{3}$ We assume that if no new/improved products or services are being introduced, no efforts of this kind have been pursued.

A categorical variable, actual innovation behavior over a period of five years (2002-2006), was created after operationalizing exploration and exploitation. Innovation behavior is described as 'actual' because it entails the actual introduction of an innovation from an exploratory or exploitative nature. Our computation of the (six) different categories in innovation behavior is represented in Figure 2-1.

Firms that did not introduce any innovations of an exploratory or exploitative nature during the period 2002-2004 or 2004-2006, but did introduce innovations in the preceding or following period, are defined as 'occasional innovators'. If, during the period 2002-2006, firms only introduced innovations that are exploitative in nature, these firms belong to the exploitation category. There is

3 The different types of exploration and exploitation are not taken into account in this study. 
no balance between actual exploration and exploitation. ${ }^{4}$ The same applies to firms that have only introduced innovations of an exploratory nature. These firms belong to the 'exploration category'. If firms have continuously introduced innovations in the period 2002-2006, but alternately of an explorative or exploitative nature, we describe this as the application of 'sequential ambidexterity'. When firms continuously introduced innovations of an exploratory and exploitative nature in the period 2002-2006, these companies apply 'simultaneous ambidexterity'. Finally, in case there is no introduction of innovations new to the firm and/or new to the market in the period 2002-2006, these firms belong to the 'no innovation category'.

Figure 2-1: Computation of actual innovation behavior constructs

\begin{tabular}{|c|c|c|c|}
\hline CIS 4 (2002-2004) & CIS 5 (2004-2006) & & Actual innovation behavior \\
\hline No Innovation & Exploitation or Exploration & $\Longrightarrow$ & \\
\hline Exploitation or Exploration & No Innovation & $\Longrightarrow$ & \\
\hline Exploitation + Exploration & No Innovation & $\Rightarrow$ & Occasional Innovation \\
\hline No Innovation & Exploitation + Exploration & $\Longrightarrow$ & \\
\hline Exploitation & Exploitation & $\Longrightarrow$ & Exploitation \\
\hline Exploration & Exploration & $\Rightarrow$ & Exploration \\
\hline Exploitation & Exploration & $\Longrightarrow$ & \\
\hline Exploration & Exploitation & $\Longrightarrow$ & \\
\hline Exploitation + Exploration & Exploitation or Exploration & $\Rightarrow$ & Sequential ambidexterity \\
\hline Exploitation or Exploration & Exploitation + Exploration & $\Longrightarrow$ & \\
\hline Exploitation + Exploration & Exploitation + Exploration & $\Longrightarrow$ & Simultaneous ambidexterity \\
\hline No Innovation & No Innovation & $\Longrightarrow$ & No Innovation \\
\hline
\end{tabular}

4 Actual relates to the effective introduction of an innovation, new to the firm and/or new to the market. 
Table 2-2 provides an overview of the frequencies of the different types of innovation behavior. ${ }^{5}$

Table 2-2: Actual innovation behavior frequencies

\begin{tabular}{lcc}
\hline Actual innovation behavior & Frequency & Percent \\
\hline & & \\
Occasional innovation & 171 & 24.7 \\
Exploitation & 20 & 2.9 \\
Exploration & 41 & 5.9 \\
Sequential ambidexterity & 125 & 18.0 \\
Simultaneous ambidexterity & 125 & 18.0 \\
No innovation & 211 & 30.4 \\
& & \\
Total & 693 & 100.0 \\
\hline
\end{tabular}

Second, we examine firm performance as our dependent variable. Whereas Tobin's Q is an often applied comprehensive performance measure in the literature of corporate finance, studies in innovation management frequently use firm profitability (Franck, Huyghebaert, \& D’Espallier, 2010). ${ }^{6}$ This study focuses on the profit dimension of performance by including profit margin as dependent variable. Profit margin is determined by calculating the net profit after taxes as a percentage of the revenues in 2006. ${ }^{7}$ Profit margin is a frequently used indicator for firm performance (Faems, de Visser, Andries, \& Van Looy, 2010; Murphy, Trailer, \& Hill, 1996). An alternative performance measure, return on assets $(R O A)$ is applied as a robustness check. This measure is closely related to profit and represents the profitability of the firm with respect to its total set of assets or resources in 2006 (Hull \& Rothenberg, 2008; Murphy et al., 1996). ${ }^{8}$

\subsection{Independent variable}

The dependent variable from our first quantitative analysis is applied as an independent variable in the second analysis where we examine the impact of actual innovation behavior on firm performance. The above mentioned Figure 2-1 shows how this independent variable is created. We distinguished six categories and transformed them into dummy variables: occasional innovation, exploitation, exploration, sequential ambidexterity, simultaneous ambidexterity, no innovation. The latter is used as the reference category for our analysis.

\subsection{Control variables}

We introduced several control variables in our analyses to control for potential confounding effects: firm size, firm age, industry, R\&D intensity and the current assets.

5 The fact that there are as many firms that apply simultaneous ambidexterity as sequential ambidexterity is coincidental. However, the frequency in terms of manufacturing and service firms is different.

6 As the majority of firms in our sample is privately owned, it would not be appropriate to calculate Tobin's q or to include the market value as a dependent variable.

7 In addition, the profit margin of 2007 was calculated to check whether the results of the analyses are similar.

8 ROA 2007 was also calculated and applied as a dependent variable as a robustness check. 
We controlled for firm size as it has been found to influence firm performance (Hannan \& Freeman, 1989; Kolluru \& Mukhopadhaya, 2017). Firm size is measured by the natural logarithm of total assets in 2006 (Franck et al., 2010; Hamadi \& Heinen, 2015).

Because firm performance is likely to vary with firm age, we included firm age as a second control variable in our models (Coad, Holm, Krafft, \& Quatraro, 2018; Pertusa-Ortega \& MolinaAzorin, 2018). Firm age (in years) was calculated by subtracting the age of the firm from the year 2006.

As there might be industry differences in terms of innovation behavior and firm performance, we added industry as a control variable (Faems et al., 2010; He \& Wong, 2004). Industry is operationalized in three ways. Whereas the main models in this chapter involve the broad category 'manufacturing or service industry', the models in appendix present the results with a more detailed industry classification for the purpose of robustness tests. Based on the first two digits of the NACE classification code, the firms in our sample were categorized as manufacturing or service firm. We identified 441 (64\%) manufacturing firms and 252 (36\%) service firms.

In Appendix 1, additional information is provided that captures the technological and knowledge dynamism of different markets. Eurostat's (2006) categorization was used to differentiate between technological and knowledge intensity of respectively the manufacturing industry (high, medium-high, medium-low, and low) and service industry (KIS, high-tech KIS, less KIS). Appendix 1 also presents a third industry categorization, using NACE codes. This third and more detailed industry distinction involves eight industries that are present in our sample.

$R \& D$ intensity was used as control variable, since it might have a significant influence on the effect of innovation behavior on firm performance (Uotila et al., 2009). R\&D intensity is calculated by dividing the total innovation or R\&D expenditures by turnover 2006 (Blindenbach-Driessen \& van den Ende, 2014).

We also applied current assets as control variable to account for the differences in the nature of assets among firms (Deloof, Lagaert, \& Verschueren, 2007). This measure is calculated as the ratio of current assets to total assets in 2006 (Hamadi \& Heinen, 2015).

\subsection{Data analysis}

We used the case studies, to investigate how service firms innovate and if their innovation practices can be compared in terms of exploration and exploitative innovation behavior. We used the quantitative data to investigate to what extent do manufacturing firms differ from service firms in their actual innovation behavior? Chi-square is applied to test for the significance in innovation behavior between service and manufacturing firms.

Hierarchical multiple regression analysis is used to investigate to what extent the different ways of actual innovation behavior over time impact firm performance. Hierarchical regression allows to conclude if the variables of our interest (dummy variables of actual innovation behavior) explain a statistically significant amount of variance in firm performance after accounting for all other variables (Raudenbush, 1988). As outliers can create bias in the regression models, we first 
eliminate all outliers (Marasinghe, 1985). ${ }^{9}$ Next, we test the assumptions of normality, linearity and homoscedasticity, after which we apply two-stage hierarchical multiple regression analyses. To make sure our conclusions hold under different assumptions, we conduct several robustness tests of which the main results are summarized in appendix.

\section{Results}

\subsection{Exploring how service firms achieve a balance between exploration and exploitation}

The results of our three exploratory case studies reveal that also in service firms, ambidexterity seems to be important. However, how exploration and exploitation occur seems to be different from non-service firms. While environmental pressure is equal for service and manufacturing firms, the interview data suggest that the role of employees might be more important in service firms.

Depending on the size of the innovation project, a group of people or a single employee develops the ideas. None of the studied cases uses a dedicated R\&D unit to foster capabilities to explore and exploit. Instead, the studied service firms emphasize their available knowledge capacities. It creates a competitive advantage and forms the foundation for innovation. By carefully selecting qualified employees, the companies try to increase and maintain these capacities. Through intensive market and customer orientation, the service firms develop innovations of an exploitative and exploratory nature.

Tables 2-3 and 2-4 summarize the main evidence from the interviews and other data sources. The data show that service firms innovate, differentiate between exploration and exploitation activities, in spite of not having a dedicated innovation unit. The three cases illustrate that the concepts of simultaneous and sequential ambidexterity equilibrium are applicable in the context of new service development, similarly to that of manufacturing firms.

9 Multiplying the interquartile range by 1.5 , followed by subtracting $1.5 \mathrm{x}$ IQR from the first quartile and adding $1.5 \mathrm{x}$ IQR to the third quartile. Any data values that are less or greater than the obtained numbers, are considered to be outliers and are excluded from the analyses (Taylor, 2019). Other approaches in terms of removing outliers did not change the results from our analyses. 
Table 2-3: Evidence from interview data case 1

Travel agency - Case 1

CEO: "We need to continuously focus on process improvements and development of new services, while taking into account our market."

"For me, exploration is of equal value to exploitation."

"Our industry is characterized by an increasing market concentration and vertical integration, which results in high competition."

"Our margins are under high pressure, even a small economic turn back has immediate consequences."

"Innovation is a concern of everyone. For example, work groups are developed to establish improvements, create new ideas, etc."

"I clearly communicate this mission and vision of our company, so every employee knows the key values of the company."

"We have a strong focus on market and customer orientation."

"We try to obtain value and service experience enhancement for each customer."

Evidence from other data sources: continuous renewal of the service portfolio through exploration (e.g. theme travels, services for new markets, gift boxes), strong focus on process innovation (e.g. supportive services like web platform, aligning of processes)

Table 2-4: Evidence from interview data cases 2 and 3

Study and design office - Case 2

CEO: "Innovation is important for us to survive in the long term."

"We are not systematically searching for new services, our focus is on process excellence through improvements of existing processes."

"Our market is characterized by price inelasticity and transparancy, little competition exists in our market."

"I strive for process improvements with a focus on automation of frequently executed tasks."

"Quality, fastness and presentation are the three key values in our company."

"Radical innovations are developed ad hoc."

"A barrier for firm growth is the problem we face in attracting and retaining qualified employees."

"Employees are stimulated to infom me in case of having innovative ideas. They can work it out when I approve the idea."

Evidence from other data sources: explorative innovation activities take place when there is a particular opportunity or need at a certain moment (e.g. development of new pipes), exploitation through process improvements is very important for the firm (e.g. design software improvement)

\footnotetext{
Wholesaler - Case 3

CTO: "We mainly focus on efficiency improvements together with our suppliers and customers, nevertheless it remains important to spend time on developing radical new services when opportunities are there."

"We are a flexible partner to our customers while we have sufficient market share and volume to have a strong and complementary relation with our manufacturing partners."

"The market environment is originally characterized by relatively strong competition. Nevertheless, our company has a unique and generalist approach in the industry because we can offer our customers every technical component and service they might need. Competition is not able to provide the same services." Sales manager: "A high customer orientation is crucial."

Business unit manager: "We want to support our customers in developing and implementing innovations."

Evidence from other data sources: statement of the managing director in a magazine "We can only distinguish ourselves from the low wage countries by a resolute focus on innovation. We believe that innovation results in better performance and knowledge sharing should be seen as the foundation of successful collaboration."
} 
From the interviews, it appears that there are several drivers that determine whether simultaneous ambidexterity or sequential ambidexterity is favored as the way to achieve a balance between exploration and exploitation. First, it seems that a highly competitive environment drives service firms towards simultaneous ambidexterity. When a high environmental pressure is experienced, firms seem to have no other choice than simultaneously exploring and exploiting in order to survive and to create competitive advantage. Second, the values carried out by top management, together with the more general strategic orientation, enable simultaneous or sequential ambidexterity. Leadership seems to play a crucial role in the innovation behavior of the studied firms. During the interviews, it became clear that employees would not invest time in exploration or exploitation activities if management would not frequently point out the importance of innovation and the balancing exploration-exploitation act. Third, available resources are critical for firms in choosing whether to simultaneously explore and exploit, or alternate both activities. For example, the study and design office considered a lack of human resources as a barrier for simultaneous ambidexterity. Firm size may facilitate simultaneous ambidexterity, but the internal organization of the firms seems to matter more. If management enables the employees to both explore and exploit at the same time, ambidexterity can be easily achieved, even in a small or medium sized company. This is how the travel agency achieved ambidexterity.

Each studied service firm experienced a growth in performance. Two service firms applied a sequential ambidexterity model, and one firm was simultaneous ambidextrous. Exploitative innovation activities are crucial for them, with a focus on creating value for the customers and improving efficiency in the service delivery. Our case research shows that exploration, resulting in radical innovations, is often ad hoc. Sequential ambidexterity perfectly fits in this strategy. Nevertheless, the travel agency firm was obliged by its highly competitive and uncertain environment to simultaneously explore and exploit. The relation between balancing exploration and exploitation and firm performance is rather unclear, but it seems to be positive for both exploration and exploitation.

\subsection{Manufacturing and service firms and their actual innovation behavior}

The following results provide insight into the extent to which manufacturing and service firms differ from each other in terms of their actual innovation behavior, measured over a period of five years on the basis of the actual introduction of innovations that are new to the firm and/or new to the market.

First, we investigate whether there is a significant difference between service firms and manufacturing firms in terms of innovation and non-innovation. We identify all firms as 'actual innovators' or 'no actual innovators'. The Chi-square test shows that there is a significant difference in actual innovation between manufacturing firms and service firms $\left(\chi^{2}(1, N=693)=8.79, p=\right.$ $.003)$. As table $2-5$ illustrates, $37 \%$ of the service firms introduced no innovations over a period of five years, while this was the case for $27 \%$ of the manufacturing firms. $63 \%$ of the service firms were actual innovators compared to $74 \%$ of the manufacturing firms. 
Table 2-5: Crosstabulation Industry * Actual innovation

\begin{tabular}{|c|c|c|c|c|c|}
\hline \multicolumn{6}{|c|}{ Industry ${ }^{\star}$ Effective innovation behavior dummy crosstabulation } \\
\hline & & \multicolumn{2}{|c|}{ No actual innovation } & \multicolumn{2}{|c|}{ Actual innovation } \\
\hline & & $\mathbf{n}$ & $\%$ & $\mathbf{n}$ & $\%$ \\
\hline \multirow[t]{2}{*}{ Industry } & Service & 94 & 37.3 & 158 & 62.7 \\
\hline & Manufacturing & 117 & 26.5 & 324 & 73.5 \\
\hline Total & & 211 & 30.4 & 482 & 69.6 \\
\hline
\end{tabular}

Second, we focus on the firms that actually introduced innovations of an exploratory and/or exploitative nature over a period of five years. Our core variable 'actual innovation behavior' entails six types of innovation behavior, as explained in the methodology section. The 'no innovation' type is excluded from the following analysis in order to examine whether there is a difference in actual innovation behavior among the innovating manufacturing firms and service firms. The Chi-square test shows that there is a significant difference in actual innovation behavior between innovating manufacturing firms and service firms $\left(\chi^{2}(4, N=482)=12.33, p=.015\right)$. The frequencies and percentages in the table below display these differences. A similar proportion of service firms and manufacturing firms are oriented towards introducing only innovations of an exploitative nature (4\%). $8 \%$ of the service firms and $9 \%$ of the manufacturing firms introduce solely innovations of an exploratory nature. $17 \%$ of the service firms apply simultaneous ambidexterity, while this is the case for $31 \%$ of the manufacturing firms. Sequential ambidexterity is present in $29 \%$ of the service firms and $24 \%$ of the manufacturing firms. Finally, $42 \%$ of the service firms belong to the category of occasional innovators compared to $32 \%$ manufacturing firms.

Table 2-6: Crosstabulation Industry * Actual innovation behavior

\begin{tabular}{|c|c|c|c|c|c|c|c|c|c|c|c|}
\hline \multicolumn{12}{|c|}{ Industry * Effective innovation behavior crosstabulation } \\
\hline & & \multicolumn{2}{|c|}{ Exploitation } & \multicolumn{2}{|c|}{ Exploration } & \multicolumn{2}{|c|}{$\begin{array}{l}\text { Simultaneous } \\
\text { ambidexterity }\end{array}$} & \multicolumn{2}{|c|}{$\begin{array}{l}\text { Sequential } \\
\text { ambidexterity }\end{array}$} & \multicolumn{2}{|c|}{$\begin{array}{l}\text { Occasional } \\
\text { innovation }\end{array}$} \\
\hline & & n & $\%$ & n & $\%$ & $\mathbf{n}$ & $\%$ & $\mathbf{n}$ & $\%$ & $\mathbf{n}$ & $\%$ \\
\hline \multirow[t]{2}{*}{ Industry } & Service & 6 & 3.8 & 13 & 8.2 & 26 & 16.5 & 46 & 29.1 & 67 & 42.4 \\
\hline & Manufacturing & 14 & 4.3 & 28 & 8.6 & 99 & 30.6 & 79 & 24.4 & 104 & 32.1 \\
\hline Total & & 20 & 4.1 & 41 & 8.5 & 125 & 25.9 & 125 & 25.9 & 171 & 35.5 \\
\hline
\end{tabular}

Appendix 2 shows the contingency tables that differentiate between technological and knowledge intensity within the manufacturing and service industry.

\subsection{Actual innovation behavior over time and firm performance}

The statistical models in this section reveal to what extent different ways of organizing for innovation over time relate to firm performance. The descriptive statistics of the dependent, control and independent variables are presented in Table 2-7. ${ }^{10}$

10 Outlier removal explains the reduction in observations from 482 to 399 firms. 
Table 2-7: Descriptive statistics

\begin{tabular}{llcccc}
\hline Variable & $\boldsymbol{N}$ & Min & Max & Mean & \multicolumn{1}{l}{ S.D. } \\
\hline Profit margin & 399 & -9.41 & 17.49 & 3.74 & 4.86 \\
Firm age & 399 & 2.00 & 87.00 & 31.44 & 21.12 \\
Firm size (log) & 399 & 7.67 & 20.87 & 16.40 & 1.87 \\
R\&D intensity & 399 & 0.0 & 13.86 & 0.08 & 0.72 \\
Current assets & 399 & -1.46 & 0.92 & 0.21 & 0.29 \\
Industry (dummy) & 399 & 0 & 1 & 0.64 & 0.48 \\
No innovation (dummy) & 399 & 0 & 1 & 0.25 & 0.43 \\
Exploitation (dummy) & 399 & 0 & 1 & 0.03 & 0.16 \\
Exploration (dummy) & 399 & 0 & 1 & 0.07 & 0.25 \\
Simultaneous ambidexterity (dummy) & 399 & 0 & 1 & 0.23 & 0.42 \\
Sequential ambidexterity (dummy) & 399 & 0 & 1 & 0.21 & 0.41 \\
Occasional innovation (dummy) & 399 & 0 & 1 & 0.23 & 0.42 \\
\hline
\end{tabular}

The correlations in the table below show that no innovation is negatively correlated to firm age $(r=$ $-.12)$, firm size $(r=-.16)$ and industry $(r=-.15)$. Simultaneous ambidexterity is positively correlated to firm age $(r=.15)$, firm size $(r=.23)$, industry $(r=.22)$. Sequential ambidexterity is positively related to R\&D intensity $(r=.13)$ and occasional innovation is negatively related to firm size $(r=-.13)$.

Table 2-8: Correlations

\begin{tabular}{|c|c|c|c|c|c|c|c|c|c|c|c|c|}
\hline & Variable & 1 & 2 & 3 & 4 & 5 & 6 & 7 & 8 & 9 & 10 & 11 \\
\hline 1. & Profit margin & & & & & & & & & & & \\
\hline 2. & Firm age & 0.07 & & & & & & & & & & \\
\hline 3. & Firm size & 0.01 & $0.20^{* *}$ & & & & & & & & & \\
\hline 4. & $\mathrm{R} \& \mathrm{D}$ intensity & -0.04 & -0.08 & 0.01 & & & & & & & & \\
\hline 5. & Current assets & $0.34^{\star *}$ & 0.10 & -0.10 & 0.09 & & & & & & & \\
\hline 6. & Industry & 0.00 & $0.24^{\star *}$ & $0.22^{* *}$ & -0.09 & 0.05 & & & & & & \\
\hline 7. & No innovation & -0.05 & $-0.12^{*}$ & $-0.16^{\star *}$ & -0.05 & -0.04 & $-0.15^{\star *}$ & & & & & \\
\hline 8. & Exploitation & 0.03 & 0.08 & -0.03 & -0.02 & 0.05 & 0.03 & -0.10 & & & & \\
\hline 9. & Exploration & -0.03 & -0.01 & 0.02 & 0.00 & 0.02 & 0.03 & $-0.15^{\star *}$ & -0.04 & & & \\
\hline 10. & $\begin{array}{l}\text { Simultaneous } \\
\text { ambidexterity }\end{array}$ & 0.03 & $0.15^{\star *}$ & $0.23^{* *}$ & -0.02 & 0.01 & $0.22^{* *}$ & $-0.31^{\star *}$ & -0.09 & $-0.14^{* *}$ & & \\
\hline 11. & $\begin{array}{l}\text { Sequential } \\
\text { ambidexterity }\end{array}$ & 0.06 & 0.03 & 0.07 & $0.13^{\star}$ & 0.08 & -0.03 & $-0.29^{* *}$ & -0.09 & $-0.13^{* *}$ & $-0.27^{\star *}$ & \\
\hline 12. & $\begin{array}{l}\text { Occasional } \\
\text { innovation }\end{array}$ & -0.03 & -0.08 & $-0.13^{*}$ & -0.05 & -0.05 & -0.07 & $-0.31^{* *}$ & -0.09 & $-0.14^{* *}$ & $-0.29^{\star *}$ & $-0.27^{* *}$ \\
\hline
\end{tabular}

Remarks: ${ }^{\star} \mathrm{p}<0.05,{ }^{* *} \mathrm{p}<0.01 ; \mathrm{n}=399$

Before conducting a hierarchical multiple regression, the assumptions of this statistical test were examined. The assumption of singularity is met as the independent variables are no combination of other independent variables. Table 2-8 shows that no independent variables are highly correlated. The collinearity statistics (Tolerance and VIF) are all within accepted limits. ${ }^{11}$ As a result, the assumption of no multicollinearity is met. All outliers identified in the original data

11 A Tolerance value between 0.61 and 0.98 and a Variance Inflation Factor (VIF) value between 1.02 and 1.64. Tolerance values should ideally be higher than 0.2 . and VIF values should be well below the rule-of-thumb cut-off of 10 (Myers, 1990; Neter, Wasserman, \& Kutner, 1990). 
were eliminated. Finally, residual and scatter plots indicate that the assumptions of normality, linearity and homoscedasticity are all met.

A two-stage hierarchical multiple regression analysis was applied with profit margin as the dependent variable. The control variables, firm age, firm size, R\&D intensity, current assets and industry were entered during stage one of the regression. Actual innovation behavior dummies were entered in stage two. Table 2-9 reports the regression statistics.

Table 2-9: Summary of hierarchical regression analysis for firm performance ${ }^{12}$

\begin{tabular}{lcc}
\hline Profit margin 2006 & Regression 1 & Regression 2 \\
Variables & & \\
\hline Control variables & 0.03 & 0.02 \\
Firm age & 0.04 & 0.04 \\
Firm size & -0.08 & $-0.08+$ \\
R\&D intensity & $0.35^{* *}$ & $0.34^{* *}$ \\
Current assets & -0.04 & -0.04 \\
Industry & & \\
& & \\
Actual innovation behavior & & 0.02 \\
Exploitation & & -0.02 \\
Exploration & & 0.04 \\
Simultaneous ambidexterity & & 0.06 \\
Sequential ambidexterity & & 0.03 \\
Occasional innovation & & \\
& & 0.13 \\
$R^{2}$ & & $5.58^{* *}$ \\
$F$ & 0.12 & 0.00 \\
$\Delta R^{2}$ & $10.94^{* *}$ & 0.32 \\
$\Delta F$ & & \\
\hline
\end{tabular}

Remarks: $+\mathrm{p}<0.1,{ }^{\star} \mathrm{p}<0.05,{ }^{* *} \mathrm{p}<0.01$

Standardized regression coefficients are reported. $\mathrm{n}=399$

Reference category: no innovation

The hierarchical multiple regression shows that in regression one, current assets contributes significantly to the regression model $(\beta=0.35, p<0.01)$. Adding the actual innovation behavior variables to the regression model has no impact on the explained variance in firm performance $\left(R^{2}\right.$ change $=.00 . F=.32, p=.903)$. The different types of actual innovation behavior are not related to firm performance. Actual innovation behavior is no significant predictor of firm performance, measured by profit margin. Together, all variables account for $13 \%$ of the variance in firm performance $\left(R^{2}=.13, F=5.58, p<0.01\right) .{ }^{13,14}$ As Appendix 3 shows, similar results are obtained in case of separate analysis for manufacturing firms and service firms only.

12 Profit margin 2006

13 The adjusted R2 =.103 or the model explains $10.3 \%$ of the variance if we take into account the sample size and number of variables added to the model.

14 No interaction effects were found to add any value to the regression models. 
We conducted several robustness checks to see whether the result that actual innovation behavior is not related to firm performance, is not just the result of our rather rough service versus manufacturing firm categorization and other variable choices.

We applied the following modifications: new dependent variable (ROA 2006), different reference years of both dependent variables (2007 and 2008 ${ }^{15}$ ), other reference categories instead of the no innovation group, interaction effects, another independent variable for actual innovation behavior $(0=$ no innovation, $1=$ innovation), alternative control variables such as different industry categorizations (see Appendix 3). In sum, the results remain similar. There is a difference in innovation behavior, but these differences do not relate to firm performance. Appendix 3 shows the models for the alternative dependent variable ROA.

\section{Discussion and conclusion}

Over the past 10 years, we have witnessed an exponential growth in ambidexterity studies. Ambidexterity is said to be crucial for firms to survive and to achieve sustainable performance. While simultaneity is the most apparent and recurrent theme among ambidexterity, a balance between exploration and exploitation can also occur in a sequential way. This chapter examines to what extent service firms differ from manufacturing firms in the way a balance between exploration and exploitation is achieved and to what extent different ways of actual innovation behavior over time relate to firm performance. These research questions are answered on the basis of three brief exploratory case studies and data of the Belgian Community Innovation Survey and Bel-first, involving 693 firms. We examine the actual innovation behavior of these firms over a period of five years. The results suggest that there is a significant difference between service firms and manufacturing firms. However, there seems to be no relation between a firm's actual innovation behavior and firm performance in the short term.

\subsection{Theoretical implications}

Balancing exploration and exploitation is widely considered a precondition for a company's prosperity (Luger et al., 2018; O'Reilly \& Tushman, 2013). Yet, many organizations struggle to achieve and maintain simultaneous exploration and exploitation (Mathias et al., 2018). Although the concept of ambidexterity has increasingly being subject of research, few attempts have been made to examine sequential ambidexterity as an alternative way to achieve this balance.

Our empirical findings suggest that both service firms and manufacturing firms are similar in terms of the importance management attaches to innovation. Comparing both sectors in this study, reveals that service firms and manufacturing firms can reach the same goals in a different way. Manufacturing firms rather pursue simultaneous ambidexterity, while service firms more often choose for sequential ambidexterity. Our case study analysis suggests that service firms can perfectly

15 We acknowledge that 2008 might be a biased year due to the emergence of the financial crisis. 
wait with investing in radically new capabilities and jump in later, when an opportunity or certain need occurs. Corresponding to descriptions of innovation in service firms (Blindenbach-Driessen \& van den Ende, 2014; Ettlie \& Rosenthal, 2011; Sundbo \& Gallouj, 2000), we found evidence that service firms seem to prefer mainly exploitative innovation activities, whereby creating value for the customers and improving efficiency in service delivery is most important. Exploration, resulting in radical innovations, occurs often ad hoc.

Whether a service firm chooses for sequential or simultaneous ambidexterity seems to depend on several factors such as the environmental pressures experienced. The influencing role of the environment in choosing between a simultaneous or sequential mechanism, is also expressed by Uotila (2018), although he did not differentiate between manufacturing and service firms. Other factors that play a role are leadership and available resources. High environmental pressures tend to favor simultaneous ambidexterity. In addition, managers who strive to stimulate exploration and exploitation should create the opportunity to pursue both activities simultaneously. However, this is easier said than done as prior research shows (Jansen, Kostopoulos, Mihalache, \& Papalexandris, 2016; O’Reilly \& Tushman, 2011).

Research has stressed the point that balancing exploration and exploitation increases firm performance (e.g. He \& Wong, 2004; Junni et al., 2013; Luger et al., 2018). However, the data in this study did not support a significant relation between ambidexterity or actual innovation behavior and firm performance.

\subsection{Managerial implications}

While this study does not find a significant relation between actual innovation behavior and firm performance, this does not imply that firms should not innovate. Instead, as the existing literature and our interview data stress, innovation is crucial for firms to survive and to achieve sustainable performance. Ambidexterity, or engaging in exploration and exploitation, is important, regardless of the industry in which a firm is located. Because the simultaneous pursuit of both exploration and exploitation might be difficult for firms, depending on conditions such as available resources and environmental circumstances, managers should be aware that ambidexterity can also be reached in a sequential way. In fact, it seems that service firms tend to favor sequential ambidexterity. However, one should try to avoid the pitfall of missing the moment when a switch to exploration or exploitation needs to be made. The difficulty of cycling through periods of exploration and exploitation instead of simultaneous pursuing both, is knowing when to focus on exploration or exploitation.

This study suggests the importance of managerial judgement or decision making. If management opts for the 'right' choice given circumstances, similar performance outcomes can be achieved.

\subsection{Limitations and avenues for future research}

This study is subject to several limitations. First, it is acknowledged among empirical researchers that an organization's high-level choices that should influence its performance, are difficult to research (Junni et al., 2013; Siggelkow \& Rivkin, 2009). R\&D and firm performance involve a 
complex interaction (Czarnitzki \& Kraft, 2010; Morbey \& Reithner, 1990). Our regression models illustrate this finding.

Second, due to data limitations, we could not investigate the impact of actual innovation behavior on a longer term than five years. It would be interesting to encompass a data observation period of 10 years or more. As Czarnitzki and Kraft (2010) explain, the true test on the profit effects of innovative activity requires a long time series on $R \& D$ input and output.

Third, due to sample size limitations we were only able to examine 252 service firms and 441 manufacturing firms. The service sector, being the dominant industry in each of the world's key economies is not represented in that proportion. Future research should use a sample with an approximately equal number of service and manufacturing firms.

Fourth, we were limited in our operationalization of exploration and exploitation because of the available data in the Community Innovation Survey. We could for example not take into account how much innovations were introduced, neither did we distinguish between structural or contextual ambidexterity.

Fifth, the case studies suggest that environmental factors might be decisive in choosing for a simultaneous or sequential ambidextrous method. However, we were unable to capture this with our CIS data. Perhaps environmental factors determine the choice and performance. Future research could study more in-depth how other elements influence the choice of a firm to apply a simultaneous or more sequential way of being ambidextrous.

We hope that our research inspires future empirical research in this area. For example, it would be interesting to investigate more in-depth how service firms in practice compare to manufacturing firms in how they organize for ambidexterity. 


\section{References}

Aboal, D., \& Tacsir, E. (2018). Innovation and productivity in services and manufacturing: the role of ICT. Industrial and Corporate Change, 27(2), 221-241. doi: 10.1093/icc/dtx030

Ahlstrom, D. (2010). Innovation and Growth: How Business Contributes to Society. Academy of Management Perspectives, 24(3), 11-24. doi: 10.5465/amp.2010.52842948

Andriopoulos, C., \& Lewis, M. W. (2010). Managing Innovation Paradoxes: Ambidexterity Lessons from Leading Product Design Companies. Long Range Planning, 43(1), 104-122. doi: 10.1016/j.lrp.2009.08.003

Benner, M. J., \& Tushman, M. L. (2003). Exploitation, exploration, and process management: The productivity dilemma revisited. Academy of Management Review, 28(2), 238-256.

Birkinshaw, J., \& Gupta, K. (2013). Clarifying the distinctive contribution of ambidexterity to the field of organization studies. Academy of Management Perspectives, 27(4), 287-298. doi: 10.5465/amp.2012.0167

Blindenbach-Driessen, F., \& van den Ende, J. (2014). The Locus of Innovation: The Effect of a Separate Innovation Unit on Exploration, Exploitation, and Ambidexterity in Manufacturing and Service Firms. Journal of Product Innovation Management, 31(5), 1089-1105. doi: 10.1111/jpim.12146

Boumgarden, P., Nickerson, J., \& Zenger, T. R. (2012). Sailing into the wind: Exploring the relationships among ambidexterity, vacillation, and organizational performance. Strategic Management Journal, 33(6), 587610. doi: $10.1002 / \mathrm{smj} .1972$

Castellacci, F. (2008). Technological paradigms, regimes and trajectories: Manufacturing and service industries in a new taxonomy of sectoral patterns of innovation. Research Policy, 37(6-7), 978-994. doi: 10.1016/j. respol.2008.03.011

Coad, A., Holm, J. R., Krafft, J., \& Quatraro, F. (2018). Firm age and performance. Journal of Evolutionary Economics, 28(1), 1-11. doi: 10.1007/s00191-017-0532-6

Czarnitzki, D., \& Kraft, K. (2010). On the profitability of innovative assets. Applied Economics, 42(15), 19411953. doi: $10.1080 / 00036840701749019$

Damanpour, F., Walker, R. M., \& Avellaneda, C. N. (2009). Combinative Effects of Innovation Types and Organizational Performance: A Longitudinal Study of Service Organizations. Journal of Management Studies, 46(4), 650-675. doi: 10.1111/j.1467-6486.2008.00814.x

de Brentani, U., \& Reid, S. E. (2012). The Fuzzy Front-End of Discontinuous Innovation: Insights for Research and Management. Journal of Product Innovation Management, 29(1), 70-87. doi: 10.1111/j.15405885.2011.00879.x

Deloof, M., Lagaert, I., \& Verschueren, I. (2007). Leases and debt: Complements or substitutes? evidence from belgian SMEs. Journal of Small Business Management, 45(4), 491-500. doi: 10.1111/j.1540627X.2007.00224.X

Derbyshire, J. (2014). The impact of ambidexterity on enterprise performance: Evidence from 15 countries and 14 sectors. Technovation, 34(10), 574-581. doi: 10.1016/j.technovation.2014.05.010

Duncan, R. (1976). The ambidextrous organization: Designing dual structures for innovation. In R. H. Killman, L. R. Pondy \& D. E. Sleven (Eds.), The management organization (pp. 167-188). New York: North Holland.

Eisenhardt, K. M., \& Martin, J. A. (2000). Dynamic capabilities: What are they? Strategic Management Journal, 21(10-11), 1105-1121. doi: 10.1002/1097-0266(200010/11)21:10/11<1105::aid-smj133>3.0.co;2-e

Ettlie, J. E., \& Rosenthal, S. R. (2011). Service versus Manufacturing Innovation. Journal of Product Innovation Management, 28(2), 285-299. doi: 10.1111/j.1540-5885.2011.00797.x

Faems, D., de Visser, M., Andries, P., \& Van Looy, B. (2010). Technology Alliance Portfolios and Financial Performance: Value-Enhancing and Cost-Increasing Effects of Open Innovation. Journal of Product Innovation Management, 27(6), 785-796. doi: 10.1111/j.1540-5885.2010.00752.x

Ferragina, A. M., Pittiglio, R., \& Reganati, F. (2014). Does multinational ownership affect firm survival in Italy? Journal of Business Economics and Management, 15(2), 335-355. doi: 10.3846/16111699.2012.707622

Franck, T., Huyghebaert, N., \& D’Espallier, B. (2010). How Debt Creates Pressure to Perform when Information Asymmetries are Large: Empirical Evidence from Business Start-ups. Journal of Economics \& Management Strategy, 19(4), 1043-1069. doi: 10.1111/j.1530-9134.2010.00277.x

Gabler, C. B., Ogilvie, J. L., Rapp, A., \& Bachrach, D. G. (2017). Is There a Dark Side of Ambidexterity? Implications of Dueling Sales and Service Orientations. Journal of Service Research, 20(4), 379-392. doi: $10.1177 / 1094670517712019$ 
Garcia-Lillo, F., Ubeda-Garcia, M., \& Marco-Lajara, B. (2016). Organizational ambidexterity: exploring the knowledge base. Scientometrics, 107(3), 1021-1040. doi: 10.1007/s11192-016-1897-2

Garcia, R., \& Calantone, R. (2002). A critical look at technological innovation typology and innovativeness terminology: a literature review. Journal of Product Innovation Management, 19(2), 110-132. doi: $10.1111 / 1540-5885.1920110$

Gersick, C. J. G. (1991). Revolutionary change theories - A multilevel exploration of the punctuated equilibrium paradigm. Academy of Management Review, 16(1), 10-36. doi: 10.2307/258605

Ghemawat, P., \& Costa, J. (1993). The organizational tension between static and dynamic efficiency. Strategic Management Journal, 14, 59-73. doi: 10.1002/smj.4250141007

Gibson, C. B., \& Birkinshaw, J. (2004). The antecedents, consequences, and mediating role of organizational ambidexterity. Academy of Management Journal, 47(2), 209-226. doi: 10.2307/20159573

Gupta, A. K., Smith, K. G., \& Shalley, C. E. (2006). The interplay between exploration and exploitation. Academy of Management Journal, 49(4), 693-706. doi: 10.2307/20159793

Hamadi, M., \& Heinen, A. (2015). Firm performance when ownership is very concentrated: Evidence from a semiparametric panel. Journal of Empirical Finance, 34, 172-194. doi: 10.1016/j.jempfin.2015.07.004

Hannan, M. T., \& Freeman, J. (1989). Organizational ecology. Cambridge, MA: Harvard University Press.

He, Z. L., \& Wong, P. K. (2004). Exploration vs. exploitation: An empirical test of the ambidexterity hypothesis. Organization Science, 15(4), 481-494. doi: 10.1287/orsc.1040.0078

Hipp, C., \& Grupp, H. (2005). Innovation in the service sector: The demand for service-specific innovation measurement concepts and typologies. Research Policy, 34(4), 517-535. doi: 10.1016/j.respol.2005.03.002

Hughes, M. (2018). Organisational ambidexterity and firm performance: burning research questions for marketing scholars. Journal of Marketing Management, 34(1-2), 178-229. doi: 10.1080/0267257x.2018.1441175

Hull, C. E., \& Rothenberg, S. (2008). Firm performance: The interactions of corporate social performance with innovation and industry differentiation. Strategic Management Journal, 29(7), 781-789. doi: 10.1002/ smj.675

International Labour Organization. (2019). Employment in services (\% of total employment): The World Bank Group.

Jansen, J. J. P., Kostopoulos, K. C., Mihalache, O. R., \& Papalexandris, A. (2016). A Socio-Psychological Perspective on Team Ambidexterity: The Contingency Role of Supportive Leadership Behaviours. Journal of Management Studies, 53(6), 939-965. doi: 10.1111/joms.12183

Jansen, J. J. P., Simsek, Z., \& Cao, Q. (2012). Ambidexterity and performance in multiunit contexts: Cross-level moderating effects of structural and resource attributes. Strategic Management Journal, 33(11), 1286-1303. doi: 10.1002/smj.1977

Jansen, J. J. P., Van den Bosch, F. A. J., \& Volberda, H. W. (2005). Managing potential and realized absorptive capacity: How do organizational antecedent's matter? Academy of Management Journal, 48(6), 999-1015. doi: $10.5465 / \mathrm{amj} .2005 .19573106$

Jick, T. D. (1979). Mixing qualitative and quantitative methods - Triangulation in action. Administrative Science Quarterly, 24(4), 602-611. doi: 10.2307/2392366

Junni, P., Sarala, R. M., Taras, V., \& Tarba, S. Y. (2013). Organizational ambidexterity and performance: A metaanalysis. Academy of Management Perspectives, 27(4), 299-312. doi: 10.5465/amp.2012.0015

Kolluru, S., \& Mukhopadhaya, P. (2017). Empirical Studies on Innovation Performance in the Manufacturing and Service Sectors Since 1995: A Systematic Review*. Economic Papers, 36(2), 223-248. doi: 10.1111/17593441.12167

Koryak, O., Lockett, A., Hayton, J., Nicolaou, N., \& Mole, K. (2018). Disentangling the antecedents of ambidexterity: Exploration and exploitation. Research Policy, 47(2), 413-427. doi: 10.1016/j.respol.2017.12.003

Leiponen, A. (2012). The benefits of R\&D and breadth in innovation strategies: a comparison of Finnish service and manufacturing firms. Industrial and Corporate Change, 21(5), 1255-1281. doi: 10.1093/icc/dts022

Leiponen, A., \& Drejer, I. (2007). What exactly are technological regimes? Intra-industry heterogeneity in the organization of innovation activities. Research Policy, 36(8), 1221-1238. doi: 10.1016/j.respol.2007.04.008

Levinthal, D. A., \& March, J. G. (1993). The myopia of learning. Strategic Management Journal, 14, 95-112. doi: 10.1002/smj.4250141009

Lewis, M. W. (2000). Exploring paradox: Toward a more comprehensive guide. Academy of Management Review, 25(4), 760-776. doi: 10.2307/259204 
Lubatkin, M. H., Simsek, Z., Ling, Y., \& Veiga, J. F. (2006). Ambidexterity and performance in small- to mediumsized firms: The pivotal role of top management team behavioral integration. Journal of Management, 32(5), 646-672. doi: 10.1177/0149206306290712

Luger, J., Raisch, S., \& Schimmer, M. (2018). Dynamic Balancing of Exploration and Exploitation: The Contingent Benefits of Ambidexterity. Organization Science, 29(3), 449-470. doi: 10.1287/orsc.2017.1189

Marasinghe, M. G. (1985). A multistage procedure for detecting several outliers in linear regression. Technometrics, 27(4), 395-399. doi: 10.2307/1270206

March, J. G. (1991). Exploration and exploitation in organizational learning. Organization Science, 2(1), 71-87. doi: $10.1287 /$ orsc.2.1.71

Mathias, B. D., McKenny, A. F., \& Crook, T. R. (2018). Managing the tensions between exploration and exploitation: The role of time. Strategic Entrepreneurship Journal, 12(3), 316-334. doi: 10.1002/sej.1287

Miller, D., \& Friesen, P. H. (1986). Porters (1980) generic strategies and performance - An empirical examination with American data Part I: Testing Porter. Organization Studies, 7(1), 37-55. doi: $10.1177 / 017084068600700103$

Morbey, G. K., \& Reithner, R. M. (1990). How R\&D affects sales growth, productivity and profitability. ResearchTechnology Management, 33(3), 11-14.

Mudambi, R., \& Swift, T. (2011). Proactive R\&D management and firm growth: A punctuated equilibrium model. Research Policy, 40(3), 429-440. doi: 10.1016/j.respol.2010.10.014

Murphy, G. B., Trailer, J. W., \& Hill, R. C. (1996). Measuring performance in entrepreneurship research. Journal of Business Research, 36(1), 15-23. doi: 10.1016/0148-2963(95)00159-x

Myers, R. (1990). Classical and modern regression with applications (2 ed.). Boston, MA: Duxbury.

Neter, J., Wasserman, W., \& Kutner, M. H. (1990). Applied Linear Statistical Models. Irwin: Homewood, IL.

O'Reilly, C. A., \& Tushman, M. L. (2004). The ambidextrous organisation. Harvard Business Review, 82(4), 74-+.

O'Reilly, C. A., \& Tushman, M. L. (2008). Ambidexterity as a dynamic capability: Resolving the innovator's dilemma. In A. P. Brief \& B. M. Staw (Eds.), Research in Organizational Behavior, Vol 28: An Annual Series of Analytical Essays and Critical Reviews (Vol. 28, pp. 185-206).

O’Reilly, C. A., \& Tushman, M. L. (2011). Organizational Ambidexterity in Action: How managers explor and exploit. California Management Review, 53(4), 5-+. doi: 10.1525/cmr.2011.53.4.5

O'Reilly, C. A., \& Tushman, M. L. (2013). Organizational ambidexterity: Past, present, and future. Academy of Management Perspectives, 27(4), 324-338. doi: 10.5465/amp.2013.0025

OECD. (2018).Defininginnovation. Retrieved 24 April2019, from https://www.oecd.org/site/innovationstrategy/ defininginnovation.htm

Pertusa-Ortega, E. M., \& Molina-Azorin, J. F. (2018). A joint analysis of determinants and performance consequences of ambidexterity. Brq-Business Research Quarterly, 21(2), 84-98. doi: 10.1016/j. brq.2018.03.001

Puranam, P., Singh, H., \& Zollo, M. (2006). Organizing for innovation: Managing the coordination-autonomy dilemma in technology acquisitions. Academy of Management Journal, 49(2), 263-280.

Raisch, S., \& Birkinshaw, J. (2008). Organizational ambidexterity: Antecedents, outcomes, and moderators. Journal of Management, 34(3), 375-409. doi: 10.1177/0149206308316058

Raisch, S., Birkinshaw, J., Probst, G., \& Tushman, M. L. (2009). Organizational Ambidexterity: Balancing Exploitation and Exploration for Sustained Performance. Organization Science, 20(4), 685-695. doi: 10.1287/orsc.1090.0428

Raisch, S., \& Zimmermann, A. (2017). Pathways to Ambidexterity: A Process Perspective on the ExplorationExploitation paradox The Oxford Handbook of Organizational Paradox (1 ed., pp. 315-332). Oxford: Oxford University Press.

Raudenbush, S. W. (1988). Educational applications of hierarchical linear models - A review. Journal of Educational Statistics, 13(2), 85-116. doi: 10.2307/1164748

Rothaermel, F. T., \& Alexandre, M. T. (2009). Ambidexterity in Technology Sourcing: The Moderating Role of Absorptive Capacity. Organization Science, 20(4), 759-780. doi: 10.1287/orsc.1080.0404

Schumpeter, J. A. (1934). The theory of economic development. Cambridge, MA: Harvard University Press.

Siggelkow, N., \& Levinthal, D. A. (2003). Temporarily divide to conquer: Centralized, decentralized, and reintegrated organizational approaches to exploration and adaptation. Organization Science, 14(6), 650669. doi: $10.1287 /$ orsc. 14.6 .650 .24870 
Siggelkow, N., \& Rivkin, J. W. (2009). Hiding the Evidence of Valid Theories: How Coupled Search Processes Obscure Performance Differences among Organizations. Administrative Science Quarterly, 54(4), 602634. doi: 10.2189/asqu.2009.54.4.602

Smith, W. K., \& Tushman, M. L. (2005). Managing strategic contradictions: A top management model for managing innovation streams. Organization Science, 16(5), 522-536. doi: 10.1287/orsc.1050.0134

Spescha, A., \& Woerter, M. (2019). Innovation and firm growth over the business cycle. Industryand Innovation, 26(3), 321-347. doi: 10.1080/13662716.2018.1431523

Sundbo, J., \& Gallouj, F. (2000). Innovation as a loosely coupled system in services (Vol. 18).

Taylor, C. (2019). How Are Outliers Determined in Statistics? Retrieved from Thought Co. website: https://www. thoughtco.com/what-is-an-outlier-3126227

Teece, D. J., Pisano, G., \& Shuen, A. (1997). Dynamic capabilities and strategic management. Strategic Management Journal, 18(7), 509-533. doi: 10.1002/(sici)1097-0266(199708)18:7<509::aid-smj882>3.0.co;2-Z

The World Bank Group. (2019a). World Bank national accounts data, and OECD National Accounts data files. Manufacturing, value added (\% of GDP): The World Bank Group.

The World Bank Group. (2019b). World Bank national accounts data, and OECD National Accounts data files. Services, value added (\% of GDP): The World Bank Group.

Tushman, M. L., \& O’Reilly, C. A. (1996). Ambidextrous organizations: Managing evolutionary and revolutionary change. California Management Review, 38(4), 8-\&. doi: 10.2307/41165852

Uotila, J. (2018). Punctuated equilibrium or ambidexterity: dynamics of incremental and radical organizational change over time. Industrial and Corporate Change, 27(1), 131-148. doi: 10.1093/icc/dtx018

Uotila, J., Maula, M., Keil, T., \& Zahra, S. A. (2009). Exploration, exploitation, and financial performanc: Analysis of S\&P 500 corporations. Strategic Management Journal, 30(2), 221-231. doi: 10.1002/smj.738

Van Looy, B., Martens, T., \& Debackere, K. (2005). Organizing for Continuous Innovation: On the Sustainability of Ambidextrous Organizations. Creativity and Innovation Management, 14(3), 208-221.

Venkatraman, N., Lee, C. H., \& Iyer, B. (2007). Strategic ambidexterity and sales growth: A longitudinal test in the software sector. Unpublished manuscript (earlier version presented at the Academy of Management meeting, 2005.

Volberda, H. W., \& Lewin, A. Y. (2003). Guest editors' introduction - Co-evolutionary dynamics within and between firms: From evolution to co-evolution. Journal of Management Studies, 40(8), 2111-2136. doi: 10.1046/j.1467-6486.2003.00414.x

Vrontis, D., Thrassou, A., Santoro, G., \& Papa, A. (2017). Ambidexterity, external knowledge and performance in knowledge-intensive firms. Journal of Technology Transfer, 42(2), 374-388. doi: 10.1007/s10961-016-9502-7

Wassmer, U., Li, S. L., \& Madhok, A. (2017). Resource ambidexterity through alliance portfolios and firm performance. Strategic Management Journal, 38(2), 384-394. doi: 10.1002/smj.2488

Wojan, T. R., Crown, D., \& Rupasingha, A. (2018). Varieties of innovation and business survival: Does pursuit of incremental or far-ranging innovation make manufacturing establishments more resilient? Research Policy, 47(9), 1801-1810. doi: 10.1016/j.respol.2018.06.011 


\section{APPENDIX 1: INDUSTRY FREQUENCIES}

Table 2-10: Industry frequencies based on technology and knowledge intensity ${ }^{16}$

\begin{tabular}{lcc}
\hline Industry & Frequency & Percent \\
\hline High-tech manufacturing & 157 & 22.7 \\
Low-tech manufacturing & 284 & 41.0 \\
KIS & 94 & 13.6 \\
Less KIS & 158 & 22.8 \\
Total & 693 & 100.0 \\
\hline
\end{tabular}

Table 2-11: Industry frequencies following the broad structure of NACE Rev. 1.117

\begin{tabular}{lcc}
\hline Industry & Frequency & Percent \\
\hline Mining and quarrying & 1 & 0.1 \\
Manufacturing & 437 & 63.1 \\
Electricity, gas and water supply & 2 & 0.3 \\
Construction & 1 & 0.1 \\
Wholesale and retail trade & 96 & 13.9 \\
Transport, storage and communications & 71 & 10.2 \\
Financial intermediation & 12 & 1.7 \\
Real estate, renting and business activities & 73 & 10.5 \\
Total & 693 & 100.0 \\
\hline
\end{tabular}

16 We collapsed high-technology and medium-high-technology classes into a single high-technology class because of the small number of cases found in the high-technology category. The same procedure was used for knowledge intensive service firms and high-technology knowledge intensive service firms (Ferragina, Pittiglio, \& Reganati, 2014).

17 The activity classification in CIS IV and CIS V (2002-2006) follow the NACE Rev 1.1 which was the classification in force at that time. 


\section{APPENDIX 2: CONTINGENCY TABLES ACTUAL INNOVATION BEHAVIOR}

Table 2-12: Crosstabulation Industry * Actual innovation ${ }^{18}$

\begin{tabular}{|c|c|c|c|c|c|}
\hline & & \multicolumn{2}{|c|}{ No actual innovation } & \multicolumn{2}{|c|}{ Actual innovation } \\
\hline & & $\mathbf{n}$ & $\%$ & $\mathbf{n}$ & $\%$ \\
\hline \multirow[t]{4}{*}{ Industry } & High-tech manufacturing & 28 & 17.8 & 129 & 82.2 \\
\hline & Low-tech manufacturing & 89 & 31.3 & 195 & 68.7 \\
\hline & KIS & 23 & 24.5 & 71 & 75.5 \\
\hline & Less KIS & 71 & 44.9 & 87 & 55.1 \\
\hline Total & & 211 & 30.4 & 482 & 69.6 \\
\hline
\end{tabular}

Table 2-13: Crosstabulation Industry * Actual innovation behavior ${ }^{19}$

\begin{tabular}{|c|c|c|c|c|c|c|c|c|c|c|c|}
\hline \multicolumn{12}{|c|}{ Industry ${ }^{\star}$ Effective innovation behavior crosstabulation } \\
\hline & & \multicolumn{2}{|c|}{ Exploitation } & \multicolumn{2}{|c|}{ Exploration } & \multicolumn{2}{|c|}{$\begin{array}{l}\text { Simultaneous } \\
\text { ambidexterity }\end{array}$} & \multicolumn{2}{|c|}{$\begin{array}{l}\text { Sequential } \\
\text { ambidexterity }\end{array}$} & \multicolumn{2}{|c|}{$\begin{array}{l}\text { Occasional } \\
\text { innovation }\end{array}$} \\
\hline & & n & $\%$ & $\mathbf{n}$ & $\%$ & $\mathbf{n}$ & $\%$ & $\mathbf{n}$ & $\%$ & n & $\%$ \\
\hline \multirow[t]{4}{*}{ Industry } & $\begin{array}{l}\text { High-tech } \\
\text { manufacturing }\end{array}$ & 3 & 2.3 & 20 & 15.5 & 41 & 31.8 & 34 & 26.4 & 31 & 24.0 \\
\hline & $\begin{array}{l}\text { Low-tech } \\
\text { manufacturing }\end{array}$ & 11 & 5.6 & 8 & 4.1 & 58 & 29.7 & 45 & 23.1 & 73 & 37.4 \\
\hline & KIS & 0 & 0.0 & 7 & 9.9 & 13 & 18.3 & 29 & 40.8 & 22 & 31.0 \\
\hline & Less KIS & 6 & 6.9 & 6 & 6.9 & 13 & 14.9 & 17 & 19.5 & 45 & 51.7 \\
\hline Total & & 20 & 4.1 & 41 & 8.5 & 125 & 25.9 & 125 & 25.9 & 171 & 35.5 \\
\hline
\end{tabular}

18 The Chi-square test shows that there is a significant difference in actual innovation behavior between the different industries $\left(\chi^{2}(3, N=693)=29.15, p=.000\right)$.

19 The Chi-square test shows that there is a significant difference in actual innovation behavior between the innovating different industries $\left(\chi^{2}(12, N=482)=47.27, p=.000\right)$. 


\section{APPENDIX 3: ALTERNATIVE HIERARCHICAL REGRESSION MODELS 20}

Table 2-14: Summary of hierarchical regression analysis for firm performance (Profit margin 2006, manufacturing firms only]

\begin{tabular}{lcc}
\hline $\begin{array}{l}\text { Profit margin 2006 - Manufacturing firms } \\
\text { Variables }\end{array}$ & Regression 1 & Regression 2 \\
\hline Control variables & 0.00 & -0.01 \\
Firm age & 0.07 & 0.05 \\
Firm size & -0.04 & -0.04 \\
R\&D intensity & $0.37^{* *}$ & $0.37^{\star *}$ \\
Current assets & $-0.10+$ & -0.10 \\
Industry (Low-tech) & & \\
& & \\
Actual innovation behavior & & -0.03 \\
Exploitation & & -0.03 \\
Exploration & & 0.05 \\
Simultaneous ambidexterity & & 0.09 \\
Sequential ambidexterity & & -0.03 \\
Occasional innovation & & \\
$R^{2}$ & & 0.16 \\
$F$ & 0.15 & $4.65^{* *}$ \\
$\Delta R^{2}$ & $8.54^{* *}$ & 0.01 \\
$\Delta F$ & & 0.80 \\
\hline Remark: &
\end{tabular}

Remarks: $+\mathrm{p}<0.1,{ }^{\star} \mathrm{p}<0.05,{ }^{* *} \mathrm{p}<0.01$

Standardized regression coefficients are reported. $\mathrm{n}=254$

Reference category: High-tech manufacturing firms

20 Appendix 3 only presents four alternative hierarchical regression analyses. These results and the outcome of other conducted regression analyses show that our primary conclusions from the main models in this chapter remain valid. 
Table 2-15: Summary of hierarchical regression analysis for firm performance (Profit margin 2006, service firms only]

\begin{tabular}{lcc}
\hline $\begin{array}{l}\text { Profit margin 2006 - Service firms } \\
\text { Variables }\end{array}$ & Regression 1 & Regression 2 \\
\hline Control variables & 0.09 & 0.10 \\
Firm age & -0.04 & -0.04 \\
Firm size & -0.12 & -0.11 \\
R\&D intensity & $0.32^{\star *}$ & $0.33^{* *}$ \\
Current assets & 0.02 & -0.06 \\
Industry (KIS) & & \\
Actual innovation behavior & & \\
Exploitation & & 0.15 \\
Exploration & & -0.01 \\
Simultaneous ambidexterity & & -0.04 \\
Sequential ambidexterity & & -0.02 \\
Occasional innovation & & 0.14 \\
$R^{2}$ & 0.12 & 0.16 \\
$F$ & $3.65^{* *}$ & $2.55^{* *}$ \\
$\Delta R^{2}$ & & 0.04 \\
$\Delta F$ & & 1.39 \\
\hline
\end{tabular}

Remarks: $+\mathrm{p}<0.1,{ }^{\star} \mathrm{p}<0.05,{ }^{* *} \mathrm{p}<0.01$

Standardized regression coefficients are reported. $\mathrm{n}=145$

Reference category: Less knowledge intensive service firms

Table 2-16: Summary of hierarchical regression analysis for firm performance (Profit margin 2006, industry classification based on technology and knowledge intensity]

\begin{tabular}{lll}
\hline $\begin{array}{l}\text { Profit margin 2006 } \\
\text { Variables }\end{array}$ & Regression 1 & Regression 2 \\
\hline Control variables & & \\
Firm age & 0.03 & 0.02 \\
Firm size & 0.04 & 0.03 \\
R\&D intensity & -0.08 & $-0.08+$ \\
Current assets & $0.34^{* *}$ & $0.34^{* *}$ \\
High-tech manufacturing & 0.03 & 0.03 \\
Low-tech manufacturing & -0.08 & -0.08 \\
KIS & 0.00 & -0.00 \\
Actual innovation behavior & & \\
Exploitation & & 0.02 \\
Exploration & & -0.03 \\
Simultaneous ambidexterity & & 0.03 \\
Sequential ambidexterity & & 0.06 \\
Occasional innovation & & 0.03 \\
$R^{2}$ & & 0.13 \\
$F$ & 0.13 & $4.92^{* *}$ \\
$\Delta R^{2}$ & $8.20^{* *}$ & 0.01 \\
$\Delta F$ & & 0.41 \\
\hline Remark: & &
\end{tabular}

Remarks: $+\mathrm{p}<0.1,{ }^{*} \mathrm{p}<0.05,{ }^{* *} \mathrm{p}<0.01$

Standardized regression coefficients are reported. $\mathrm{n}=399$

Reference category: Less KIS 
Table 2-17: Summary of hierarchical regression analysis for firm performance [ROA 2006]

\begin{tabular}{lcc}
\hline ROA 2006 & & \\
\hline Variables & Regression1 & Regression2 \\
\hline Control variables & 0.04 & 0.04 \\
Firm age & -0.07 & -0.08 \\
Firm size & $-0.10^{*}$ & $-0.10^{*}$ \\
R\&D intensity & $0.33^{* *}$ & $0.32^{* *}$ \\
Current assets & -0.05 & -0.05 \\
Industry & & \\
Actual innovation behavior & & \\
Exploitation & & 0.01 \\
Exploration & & -0.03 \\
Simultaneous ambidexterity & & 0.04 \\
Sequential ambidexterity & & 0.02 \\
Occasional innovation & & 0.01 \\
$R^{2}$ & & \\
$F$ & 0.12 & 0.13 \\
$\Delta R^{2}$ & $10.95^{* *}$ & $5.56^{* *}$ \\
$\Delta F$ & & 0.00 \\
\hline$R$
\end{tabular}

Remarks: $+\mathrm{p}<0.1,{ }^{\star} \mathrm{p}<0.05,{ }^{* *} \mathrm{p}<0.01$

Standardized regression coefficients are reported. $\mathrm{n}=397$

Reference category: no innovation 


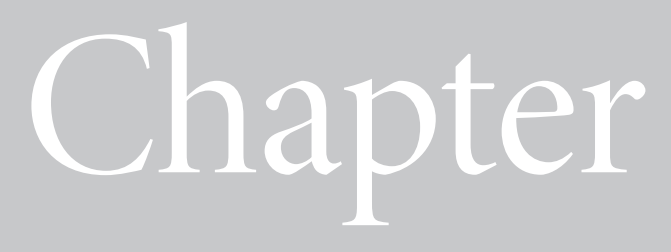

\section{Does spatial ambidexterity pay off? On the benefits of} geographic proximity between technology exploitation and exploration'

This chapter is based on the paper: Geerts, A., Leten, B., Belderbos, R. \& Van Looy, B. 2018. Does Spatial Ambidexterity Pay Off? On the Benefits of Geographic Proximity Between Technology Exploitation and Exploration. Journal of Product Innovation Management, 35(2): 151-163. 


\section{Abstract}

While most scholars tend to agree that it is worthwhile for firms to strive for ambidexterity, less consensus exists on how to organize simultaneously for exploration and exploitation. Although firms increasingly conduct R\&D activities in multiple locations and countries, prior ambidexterity research has ignored a geographical dimension in explaining the ambidexterity-performance relationship. In this article, we develop and validate the concept of 'spatial ambidexterity' which we define as the degree to which firms pursue technology exploration and exploitation in proximate locations. We argue that both activities benefit from proximity as firms will increase their ability to enact cross fertilization opportunities and synergies between explorative and exploitative technological activities. Relying on a panel dataset (1995-2003) of the technological activities of 156 large R\&D intensive European, US and Japanese firms, we examine the degree to which technology exploration and exploitation activities are pursued simultaneously in similar or different geographical regions. Patent data are used to construct indicators of technology exploration and exploitation activities. Spatial ambidexterity is measured as the degree to which global technology exploration and exploitation activities are pursued in proximity. Our analysis confirms that firms exhibiting greater geographic proximity between technology exploration and exploitation activities display an elevated level of technological performance. Both technology activities of an explorative and exploitative nature appear to benefit from spatial proximity. 


\section{Introduction}

Innovating firms engage in both technology exploitation and exploration in order to be effective in the short run and to survive and prosper in the long run (Benner \& Tushman, 2003; Gupta, Smith, \& Shalley, 2006; Lavie, Kang, \& Rosenkopf, 2011; March, 1991). Technology exploitation refers to the refinement and extension of existing technologies, leading to predictable, shortterm returns. Technology exploration refers to experimentation with new technologies, implying more uncertain returns unfolding over longer timeframes (Levinthal and March, 1993). Scholars advanced the concept of organizational ambidexterity as a firm's ability to engage (effectively) in both (technology) exploitation and exploration (e.g. Gibson \& Birkinshaw, 2004; Tushman \& O’Reilly, 1996).

Organizational ambidexterity remains a challenge for firms: Exploitation and exploration compete for scarce corporate resources, have distinct objectives, and imply different activities, cultures, processes and organizational routines. Whereas flexible, organic structures are preferred for exploration purposes, efficiency-oriented, mechanistic organizational practices are better suited for exploitation activities (Burns and Stalker, 1961; Abernathy, 1991; Ghemawat et al., 1993; Benner and Tushman, 2003; Jansen et al., 2006; Stettner and Lavie, 2014).

While some scholars (most notably Gibson and Birkinshaw, 2004) suggest that a firm can balance exploration and exploitation within a single organizational unit by building a context that is simultaneously challenging and supportive, i.e. contextual ambidexterity, other scholars call for a separation of both activities across different organizational units (Jansen et al., 2010; O'Reilly and Tushman, 2004) or even across the boundaries of the firm by engaging in alliances and acquisitions (Stettner and Lavie, 2014). This separation, defined as structural ambidexterity, allows for the installment of processes, routines and cultures that are aligned with the specific needs of exploration and exploitation (O'Reilly and Tushman, 2004).

However, the structural separation of technology exploration and exploitation can jeopardize cross-fertilization and synergies between the two activities (Van Looy, Martens, \& Debackere, 2005). It has therefore been argued that firms have to complement the separation of exploration and exploitation activities with subtle ways of integrating and/or coordinating both activities. The literature has focused in this respect on the potentially facilitating role of senior management teams and unit-spanning task forces to identify and enact possible synergies between exploration and exploitation activities (O'Reilly and Tushman, 2004; Jansen et al., 2010; Tushman et al., 2010).

In this article, we contribute to the literature on organizing for organizational ambidexterity by arguing that the potential to coordinate between exploration and exploitation activities also depends on the spatial configuration of firms' technology exploration and exploitation activities. More specifically, we introduce the concept of spatial ambidexterity as the extent to which firms jointly pursuit technology exploration and exploitation in spatial proximity. With the increasing internationalization of $R \& D$ activities by multinational firms, the spatial dimension of the organization of R\&D has received recent ample attention (e.g. Lahiri, 2010; Belderbos et al., 2015; OECD, 2007) but the consequences for ambidexterity have not been examined. We argue that 
spatially ambidextrous organizational structures provide better opportunities for firms to create linkages and synergies between technology exploration and exploitation activities, as knowledge exchange and knowledge creation processes benefit from the geographic proximity of individuals who engage in either exploration or exploitation activities.

We examine the role of spatial ambidexterity by relying on a panel dataset (1995-2003) on the technological activities of 156 large European, US and Japanese firms that are active in five R\&D intensive manufacturing industries. Patent data are used to construct indicators of technology exploration and exploitation and to derive information on the locations where technological activities occur. Spatial ambidexterity is measured as the degree to which technology exploration and exploitation activities are pursued within similar regions. The analysis includes regions spanning the major locations of technological activities in the world (US states, European NUTS3 regions, Japanese prefectures and Chinese provinces). Empirical findings suggest that firms adopting spatial ambidextrous organizational structures exhibit elevated levels of technological performance. Both explorative and exploitative technological activities benefit from spatial proximity. Our study thus reveals the importance of the - hitherto neglected - spatial dimension when organizing for organizational ambidexterity.

The next section discusses the background literature and provides the argumentation for our hypothesis on spatial ambidexterity. The third section discusses the methodology and the data, and is followed by the empirical results. The final section discusses the key findings and the managerial and theoretical implications of the study, and concludes with limitations and avenues for future research.

\section{Background literature and hypothesis}

The concepts of exploration and exploitation have their roots in organizational learning theory and became prominent themes in the innovation literature since the seminal article of March (1991). Technology exploitation refers to the refinement and extension of existing technologies and implies activities like refinement, selection and implementation. Technology exploration refers to the creation of new technologies and implies activities such as search, discovery and experimentation (March, 1991; Gupta et al., 2006). According to March (1991), exploration and exploitation are distinctive activities and firms should devote attention and resources to both. Organizations that engage only in exploration are likely to end up with too many undeveloped ideas and few distinctive competences (Levinthal and March, 1993). Conversely, firms that focus exclusively on exploitation might end up in competency traps (Levitt and March, 1988; Levinthal and March, 1993) and might experience that core capabilities (Prahalad and Hamel, 1990) turn into core rigidities (Leonard-Barton, 1992) when they face competence destroying changes.

Inspired by Duncan (1976), Tushman and O'Reilly (1996) advanced the concept of organizational ambidexterity as a firm's ability to engage in both exploitation and exploration (effectively). Several empirical studies have demonstrated the value of organizational ambidexterity for firms. Using 
survey data on a sample of 206 firms, He and Wong (2004) showed that maintaining a balance between explorative and exploitative innovation activities is positively related to sales growth. Using, respectively, data on corporate press coverage and patents, Uotila et al. (2009) and Belderbos et al. (2010) found evidence for an inverted u-shaped relationship between the relative emphasis of firms on exploration versus exploitation and their (long-term) financial performance. Hence, firms that balance their attention between exploration and exploitation activities outperform their more focused counterparts that focus more exclusively on exploration or exploitation.

The optimal balance between exploration and exploitation differs across firms and depends on the characteristics of the external environment that firms face (March and Levinthal, 1993). In dynamic environments, characterized by frequent changes in technologies, customer preferences and product demand, current technologies may become obsolete and firms need to invest more in exploratory innovations (Jansen et al., 2006; Uotila et al., 2009). In contrary, when firms operate in competitive environments with strong pressures for efficiency increases and price reductions, it is importance to invest more in exploitative innovations (Jansen et al., 2006).

Organizational scholars have stated that exploration and exploitation activities require different mindsets, processes and working routines to be effective (Tushman and O'Reilly, 2004; Stettner and Lavie, 2014). Exploration benefits from high levels of autonomy, flexible routines and risk taking. The opposite is true for exploitation which is more productive under conditions of predictability, centralization of control and formalized routines (Benner and Tushman, 2003; Jansen et al., 2006; McGrath, 2001). These different requirements complicate the joint pursuit of exploration and exploitation activities within firms (Tushman and O'Reilly, 1996).

While there is broad agreement on the need for organizational ambidexterity, there is considerably less clarity on how firms should organize to achieve this balance (Gupta et al., 2006). A popular view in the literature is that exploration and exploitation activities should be separated due to their conflicting requirements. Some scholars suggest to implement a temporal separation in which a firms shift between periods of exploration and exploitation. For instance, Brown and Eisenhardt (1997) demonstrated in their study of small electronics firms that firms use rhythmic switching to cycle through periods of exploration and exploitation. Relying on a simulation study, Siggelkow and Levinthal (2003) suggest that the temporal sequencing of organizational structures between exploration and exploitation can be an adequate way of organizing. However, while temporal separation may work well for small organizations, it may be less relevant for large firms that are typically active in multiple businesses and manage diverse technology portfolios (Leten, Belderbos and Van Looy, 2007) reflecting different technology lifecycle dynamics and needs for exploration or exploitation (Tushman and O’Reilly, 1996).

A second solution that has been put forward in the literature implies separating exploration and exploitation activities by situating them in different organizational units (Tushman and O'Reilly, 2004; Jansen et al., 2010; Fang, Lee and Schilling, 2010) or even outside the boundaries of the firm by engaging in alliances and acquisitions (Stettner and Lavie, 2014). Studying the development of 22 explorative innovations in 13 different business units, Tushman et al. (2010) found that firms frequently organize explorative innovations in separate organizational units. 
Scholars that advocated the use of structural separation mechanisms (Tushman and O'Reilly, 1996 \& 2004; Jansen et al., 2010) have at the same time pointed at the importance of integration mechanisms to create synergies between exploration and exploitation activities. Jansen et al. (2010) found that the relationship between structural separation and organizational ambidexterity is mediated by senior team and organizational integration mechanisms, such as the use of task forces that bring together employees from exploration and exploitation units. The simulation study of Fang et al. (2010) suggests that firms can achieve the highest performance when exploration and exploitation occur in small semi-autonomous subunits with a moderate level of cross-group linking.

Whereas firms increasingly disperse their technology development activities around the globe (OECD, 2007; UNCTAD, 2005), existing ambidexterity studies have not taken into account the spatial configuration of firms' technology exploration and exploitation activities and its implications for firms' performance. In the next section, we provide an argumentation why it is important to consider the spatial dimension of exploration and exploitation activities. More specifically, we will introduce the concept of spatial ambidexterity and argue that firms can increase their technological performance by pursuing technology exploration and exploitation activities that are situated close to each other.

\section{The rationale for spatial ambidexterity}

Firms are increasingly organizing technology exploration and exploitation activities in multiple geographical regions and countries (Moncada-Paterno-Castello, Vivarelli, \& Voigt, 2011), with potential consequences for the joint pursuit of exploration and exploitation. This spatial dimension of ambidexterity has thus far not been studied and can bring valuable insights as to how a firm's exploration and exploitation activities should be organized to improve innovation performance. Drawing on arguments from the literature on organizational learning and innovation management, we expect that firms can increase their technological performance by adopting spatial ambidextrous organizational structures: i.e. organizational arrangements whereby technology exploration and exploitation are pursued in geographic proximity.

As highlighted above, the success of ambidextrous organizations depends on the extent to which firms are able to cross-fertilize and create synergies between exploration and exploitation activities (Van Looy et al., 2005). The presence of a variety of technology activities might provide the foundations and tools that enable inspiration as well as efficiency (Adler, Goldoftas, \& Levine, 1999; Zollo \& Winter, 2002). Hargadon (1998) proposed in this respect a theory of innovation through knowledge brokering, referring to the process of (re)combining existing knowledge elements into new knowledge. The development of new knowledge might benefit from knowledge that is already available in a firm, and vice versa: existing knowledge and resources can be combined into new capabilities, and new knowledge and resources can strengthen existing competencies (Cao, Gedajlovic, \& Zhang, 2009).

More specifically, firms that manage to create linkages between exploration and exploitation activities may benefit from economies of scale and scope when developing technology. Scale 
economies result from the sharing of infrastructure, laboratories, IT systems, and specialized employees (Fung, 2002) across exploration and exploitation activities. Economies of scope refer to synergies in technology development resulting from engagement in the development activities across a range of technologies (Leten, Belderbos and Van Looy, 2007). The resulting variety enables innovation through 'technology fusion', i.e. combining and fusing knowledge originating from diverse knowledge domains (Kodama, 1992). Innovations that span technological boundaries are found to be, on average, of a higher (technical) value (Rosenkopf and Nerkar, 2001; Nerkar and Roberts, 2004; Phene et al., 2006; Ahuja and Lampert, 2001).

While the establishment of linkages and the search for synergies between exploration and exploitation activities can be stimulated and orchestrated by senior management teams and crossunit task forces (Tushman and O'Reilly, 2004; Jansen et al., 2010), the actual exchange of knowledge and the engagement in joint technology efforts resides in the interactions of corporate scientists and engineers involved in either technology exploration or exploitation. Such collaboration and knowledge exchange is facilitated by spatial proximity.

Knowledge exchange and collaboration between scientists and engineers is easier in spatial ambidextrous firms where exploration and exploitation are undertaken in close geographic proximity. A key reason is that some, and often the most valuable parts, of knowledge are difficult to articulate and hence 'tacit' or 'sticky' in nature (Polanyi, 1966; Nelson and Winter, 1982; von Hippel, 1994). Tacit knowledge resides in the heads and practices of scientists and engineers engaged in its production (von Hippel, 1994) and require rich knowledge transfer channels, like direct, face-to-face interactions that are promoted by geographical proximity (Nonaka, 1994; Leten, Landoni and Van Looy, 2014). Furthermore, geographic proximity may increase chances for serendipitous encounters between corporate scientists and engineers that focus on either exploration or exploitation activities (Allen, 1977). These meetings may be an important source of inspiration and ultimately synergies in technology development for firms.

Combined, these observations and arguments suggest that firms may benefit from organizing explorative and exploitative technology activities in spatial proximity to each other.

Hypothesis: Spatial ambidexterity (a higher degree of spatial proximity between a firm's technology exploration and exploitation activities) is positively associated with technological performance.

\section{Methodology and data}

\subsection{Sample and data collection}

The relationship between spatial ambidexterity and the technological performance of firms is investigated using a panel dataset (1995-2003) on the technological activities of 156 sample firms. The sample firms are R\&D-intensive European, US and Japanese firms in five industries: (i) non-electrical machinery, (ii) pharmaceuticals \& biotechnology; (iii) chemicals; (iv) IT hardware (computers and communication equipment); and (v) electronics \& electrical machinery. The firms 
are drawn from the $2004 \mathrm{EU}$ industrial R\&D investment scoreboard, which provides listings of the 500 most R\&D-intensive European, and 500 most R\&D-intensive US and Japanese firms across all industries. This resulted in an initial sample of 186 firms. Subsequently, we limited the sample to those 156 firms that engage in both technology exploration and exploitation in the observation period. This gives us a maximum number of 1404 (i.e. 156 times 9) observations. Since spatial ambidexterity can only be measured when a firm engages in both exploration and exploitation in a certain year, the actual number of observations in the regressions is reduced to 1132 (as we didn't observe exploration for a number of year/firm observations). The selected firms are the top R\&D spenders in their region of origin and industry. The sample contains around the same number of firms in each industry for each country of origin (Table 3-1). Whereas the sample firms have their headquarters in 13 countries, technological (invention) activities occur in up to 29 countries and up to 158 different regions on a yearly basis.

Table 3-1: Sample firm distribution by industry and region of origin

\begin{tabular}{lccc}
\hline Industry & Europe & United States & Japan \\
\hline Chemicals & 12 & 10 & 10 \\
Pharmaceuticals and Biotechnology & 10 & 13 & 8 \\
Engineering and General Machinery & 11 & 9 & 9 \\
IT hardware & 11 & 14 & 12 \\
Electronics and Electrical Machinery & 7 & 6 & 14 \\
Total & 51 & 52 & 53 \\
\hline
\end{tabular}

Patent data from the European Patent Office (EPO) are used to construct indicators of firms' technological activities (exploration and exploitation) at the consolidated level: all patents of the parent firm and its consolidated (majority-owned) subsidiaries. We used lists of subsidiaries included in corporate annual reports, $10-\mathrm{K}$ reports filed with the SEC in the US and, for Japanese firms, information on foreign subsidiaries published by Toyo Keizai in the yearly 'Directories of Japanese Overseas Investments' to establish consolidated corporate groups. As changes can occur in a firm's group structure, the consolidation is conducted on an annual basis (1995-2003). We opt for patent application data (rather than grants) as applications provide a better indication of technological activities of a more explorative nature. Data from the European Patent Office (EPO) are preferred to data from the United States Patent and Trademark Office (USPTO) as EPO patents are considered to provide a better indication of valuable technological activities. This is because the cost of patenting is two to five times greater at EPO than at USPTO, the workload of patent examiners is four times smaller at EPO, and EPO has a 20-30\% lower patent-granting rate than USPTO (Jaffe \& Lerner, 2004; Quillen \& Webster, 2001; Van Pottelsberghe de la Potterie \& François, 2006). 


\subsection{Dependent variable}

The main dependent variable in this study is the annual (1996-2003) technological performance of a firm (Technological performance), measured by the number of patent applications weighted by their forward citations. Patent counts weighted by citations overcome the limitations of simple counts by taking into account the value of innovations (Trajtenberg, 1990). Patent citation counts are constructed based on a fixed time window of eight years after the patent's application date, as most patents receive the bulk of citations after a period of eight years. The dependent variable (technological performance) is a count variable. We therefore rely on count data models as they take into account the non-negativity and discreteness of the dependent variable (Cameron and Trivedi, 1998). We use Negative Binomial count data models that control for over-dispersion in the dependent variable. We employ fixed-effects estimations to control for unobserved firm level heterogeneity that may affect technological performance.

In order to measure whether firms adopt spatial ambidextrous organizational structures, we classify the total number of patent applications into two groups: exploratory and exploitative patents. Technology class information is used to make a distinction between explorative and exploitative patents. The EPO classifies all patents into at least one technology field, using the International Patent Classification System (IPC). The IPC system classifies the technology landscape into 628 IPC-4 digit classes (used in the study) and several ten-thousands of subclasses nested within these classes. In line with Belderbos et al. (2010), a patent is defined as explorative when it is situated in a technology field that is new or unfamiliar to the firm. A technology field is considered as new to a firm in year $t$, if the firm did not patent in the technology field in the past five years ( $t-5$ to $t-1)$. Due to the often fast transformation of technological knowledge, a five-year window is chosen to evaluate experience with technology fields (Ahuja \& Lampert, 2001; Hall, Jaffe, \& Trajtenberg, 2005; Leten, Belderbos, \& Van Looy, 2007). Because a technology field is likely to remain relatively new and unexplored for the firm immediately after the firm becomes involved in it, a technology field keeps its explorative rating for a period of three successive years.

In total, 187,292 patent applications (belonging to the 156 sample firms for the period 19952003) are classified as explorative or exploitative. The patent data are used to construct the relevant variables related to exploitation, exploration and innovation performance at the firm level. The majority of patents are classified as exploitation (92\%), and hence the remainder obtain the status of exploration (8\%). The average share of exploration patents at the firm-level (calculated for the panel of 1132 observations in the regression models) is $19 \%$. The median value of this variable is $0.14(14 \%)$ and it ranges between 0.01 and 0.92 across sample observations.

\subsection{Spatial ambidexterity}

Spatial ambidexterity is measured as the degree to which technology exploration and exploitation activities of a firm are pursued globally within similar regions. To identify the location(s) where explorative and exploitative technological activities have been conducted, we rely on inventor address information on explorative and exploitative patents. Allocation based on inventor addresses is the most commonly used approach in patent studies since - especially for large firms 
- allocation based on assignee addresses might reveal the location of corporate headquarters rather than the actual place where technological activity, resulting in a patent, took place (Deyle \& Grupp, 2005; Khan \& Dernis, 2006). Locations of firms' R\&D activities are identified at the level of regions that are roughly comparable in population size: US states, Japanese prefectures, Chinese provinces and NUTS 3 regions in Europe. On a yearly base, our sample firms on average pursue technological activities in 19 different regions around the world.

We create for each firm and year two vectors that represent the distribution of respectively the exploration and exploitation patents over the different geographical regions. The degree of spatial ambidexterity of a firm is measured by calculating the cosine between the exploration and exploitation vectors. ${ }^{21}$ Specifically, the cosine index $S_{i j}$ measures the angular separation between the vectors representing the exploration $(i)$ and exploitation $(j)$ activities within all the locations (k) where a firm pursued technological activity that resulted in patents:

$$
\mathrm{S}_{i j=} \sqrt{\frac{\sum_{k=1}^{m} \mathrm{C}_{i k} * \mathrm{C}_{j k}}{\sqrt{\sum_{\dddot{k}=1} \mathrm{C}^{2} i k} * \sqrt{\sum_{\dddot{k}=1} \mathrm{C}^{2} j k}}}
$$

$\mathrm{S}_{i j}$ takes larger values if a firm pursues exploratory and exploitative inventive activities within the same locations. It is equal to one for pairs of exploratory and exploitative activities with an identical locational distribution, while it goes to zero for pairs of exploratory and exploitative activities in locations that do not overlap. In other words, a value close to 1 indicates a high degree of spatial ambidexterity. The measure of spatial ambidexterity is lagged with one year in the regressions to allow for a time lag between a firm's organizational structure and the output (patents) of R\&D activities. The short time lag of one year is consistent with the findings of Hall et al. (1983) who found evidence for a time lag of one year between R\&D investments and patents.

\subsection{Control variables}

The study's empirical models control for other factors that are likely to impact firms' technological performance. All variables are one-year lagged. The models also include seven time dummies to account for time specific factors affecting the number of patent applications.

$R \& D$ expenses. Firms that invest more in $R \& D$ are expected to generate more patentable inventions (Pakes \& Griliches, 1984). We control for one-year lagged logarithmically transformed R\&D expenditures of the firm, measured in constant U.S. dollars (millions). The data on R\&D expenditures are collected from corporate annual reports, Worldscope, and Compustat. We create a proxy for the R\&D expenditures related to exploratory inventive activities ( $R \nLeftarrow D$ expenditures exploration) by multiplying the total $R \& D$ expenditures of a firm with its exploration share in patents. The $R \& D$ expenditures for exploitative inventive activities ( $R \& D$ expenditures exploitation) of a firm are calculated in a similar way. In line with total $\mathrm{R} \& \mathrm{D}$ expenditures, both of these variables are logarithmically transformed.

21 Prior work relied on a cosine index to measure the similarity of technology profiles of firms (Jaffe, 1986) or the technological relatedness of technology fields (Breschi et al., 2003). 
Patent Propensity. Patent propensity is measured as the ratio of patents to $R \& D$ expenditures. This variable controls for differences across firms in their propensity to apply for patents. In parallel with R\&D expenditures, we also create separate variables for the patent propensity related to technology exploration (patent propensity exploration) and exploitation (patent propensity exploitation). These variables are constructed as the ratio of exploration (exploitation) patents and exploration (exploitation) to R\&D expenditures.

Technological diversification. Firms that have a more diversified technology portfolio can benefit from economies of scope and knowledge spillovers in technology development (Leten et al., 2007; Quintana-Garcia \& Benavides-Velasco, 2008). The analysis therefore controls for the level of technological diversification, defined as the spread of a firm's patents over technology fields (measured by IPC 4-digit classes on patents). In line with Leten et al. (2007) and QuintanaGarcia and Benavides-Velasco (2008) we employ a number equivalent index, which is the inverse of the Herfindahl index of concentration. Let $\mathrm{N}_{i}$ denote the number of patents of a certain firm that belong to technology field $i$, such that $\mathrm{N}=\sum_{i} \mathrm{~N}_{i}$, then technological diversification is calculated as $1 /\left(\sum_{i}\left(\mathrm{~N}_{i} / \mathrm{N}\right)^{2}\right)$. The technological diversification index takes higher values if firms are active in more technology fields and have spread their competencies more equally across these fields. We include both the linear and quadratic terms of technological diversification in our models to allow for possible negative effects of excessive technological diversification (Leten et al., 2007).

Geographic diversification. We also control for the geographic diversification of firms' technological activities. Firms that spread their R\&D activities over multiple countries get access to geographically dispersed pockets of scientific and technological expertise and local customers, which may provide insights for the development of new inventions (Belderbos et al., 2015; PennerHahn \& Shaver, 2005; Todo \& Shimizutani, 2008). Geographic diversification is measured as the inverse of the Herfindahl index of concentration of a firm's patents over countries.

Exploration orientation. Even though all sample firms engage in both exploration and exploitation, there are important firm-level differences in the emphasis that is placed on technology exploration. The exploration orientation of a firm indicates the relative importance that it attaches to exploration (Heyden et al., 2015; Uotila et al., 2009) and is measured as the share of exploration patents in the total patents. Firms that have a higher exploration orientation may exhibit a lower (short-term) technological performance since exploration activities are characterized by high levels of uncertainty and higher failure rates (March, 1991; Mitchell \& Singh, 1992). 


\section{Empirical results}

The descriptive statistics and correlations between the dependent and independent variables used in this study are shown in table 3-2. There is a positive and significant correlation $(0.22)$ between spatial ambidexterity and firm's technological performance. There are no excessively high correlations between the variables that are used simultaneously in the same models.

Table 3-3 shows the results of the fixed-effects negative binomial regression analyses in which we test our central hypothesis that firms adopting spatial ambidextrous structures exhibit an elevated technological performance. Model 1 only includes the control variables and shows that both $\mathrm{R} \& \mathrm{D}$ expenditures and patent propensity are positively and significantly related to technological performance. Technological diversification has an inverted U-shaped relationship with technological performance as evidenced by the positive and significant linear term and the negative and significant quadratic term. The top of the inverted U-curve is reached at the value of 25 , which is lower than the maximum sample value of 59 . We observe a significantly negative effect of exploration orientation but no significant effect of geographic diversification.

In model 2, we add the spatial ambidexterity variable. As shown by the log likelihood ratio test (model 2 vs. model 1) adding this variable increases the model fit. The coefficient of spatial ambidexterity is positive and significant. This confirms our hypothesis: Spatial ambidexterity (a higher degree of spatial proximity between a firm's technology exploration and exploitation activities) is positively associated with technological performance.

We conducted additional analysis to examine whether spatial ambidexterity has differential effects on the exploration and exploitation performance of firms. These results are reported in models 3-4 (exploration performance) and 5-6 (exploitation performance). Most of the control variables have a similar effect as in the analysis of total technological performance. The only difference is the insignificance of $R \& D$ expenditures in the exploration analysis. A possible explanation is that we rely on a proxy due to a lack of actual data on exploration R\&D expenditures. Adding spatial ambidexterity to the exploitation and exploration models again increases the model fit as evidenced by the log likelihood ratio tests. The coefficient of spatial ambidexterity is positive and significant in both the exploration and exploitation models, with similar coefficient sizes and with the significance level the highest in the exploitation model. Both technology exploration and exploitation activities appear to benefit from the organization of exploration and exploitation in spatial proximity. 


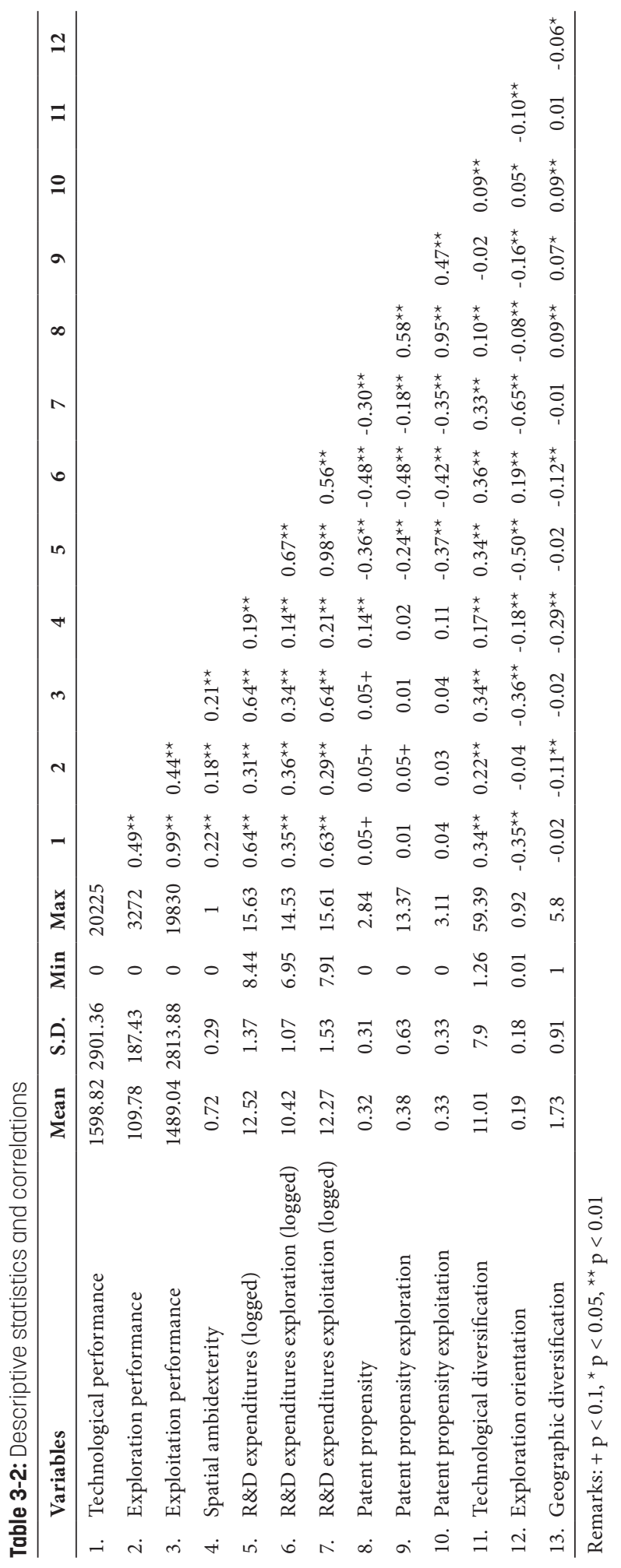




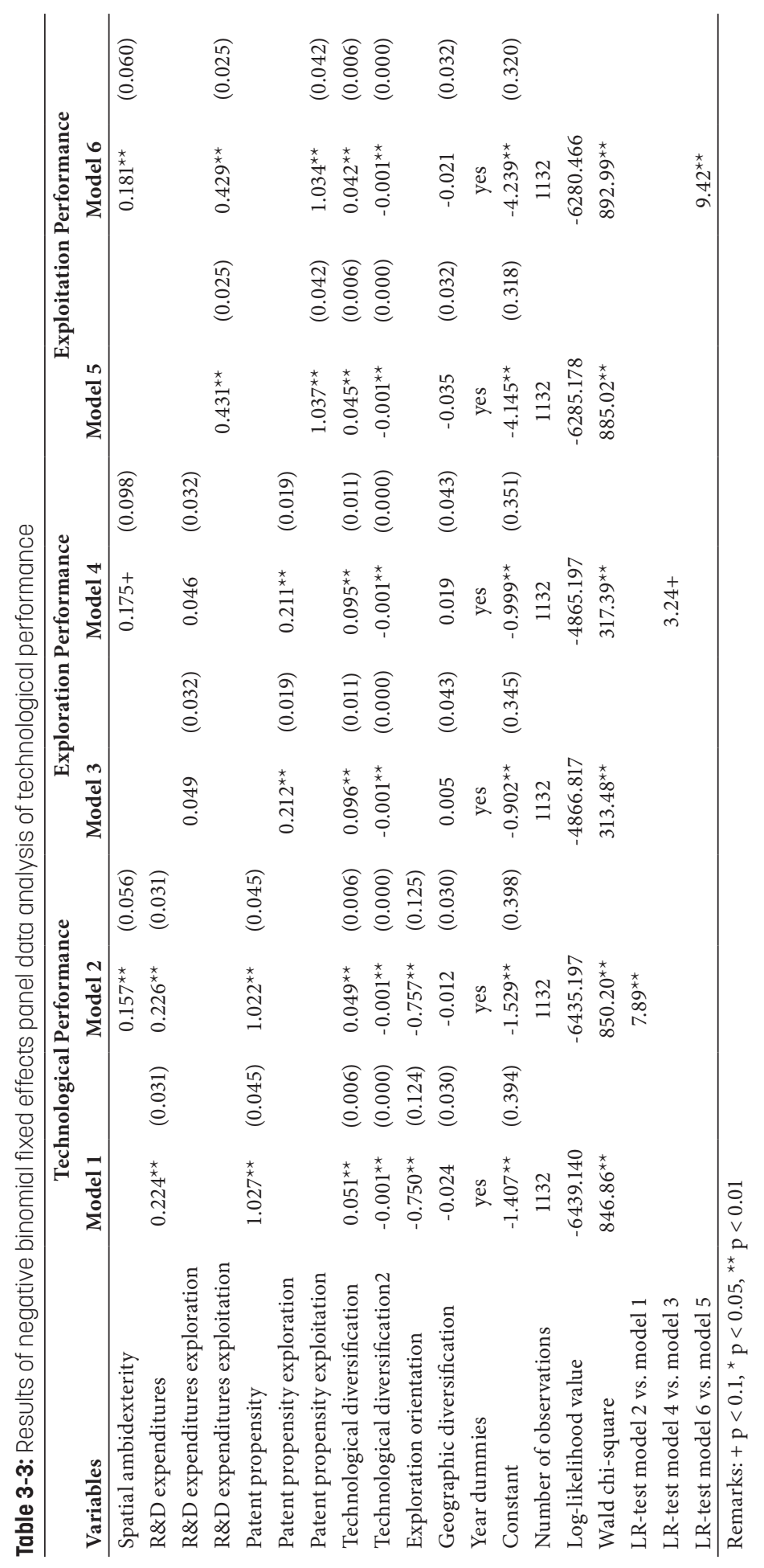




\section{Conclusion and discussion}

While extant literature agrees that organizational ambidexterity is an objective worthwhile to pursue, how firms should organize explorative and exploitative efforts effectively remains subject to scholarly debate. In this article, we develop and validate the concept of 'spatial ambidexterity' which we define as the simultaneous pursuit of technology exploitation and exploration activities in geographic proximity. Utilizing a panel dataset (1995-2003) of 156 large European, US and Japanese R\&D intensive firms, we examine the impact on firms' technological performance of the degree to which exploration and exploitation are pursued in similar or different geographical regions in the world. Our findings reveal that spatial ambidextrous organizational structures pay off in terms of technological performance.

When distinguishing between technological performance of an exploitative nature and technological performance of an exploratory nature, our analysis shows that both types of technology activities benefit from spatial proximity to each other. Hence, while a number of scholars assert that exploitation may provide the foundations and tools that enable exploration (Adler et al., 1999; Zollo \& Winter, 2002), our analysis suggest that exploitation also benefits from (proximity to) exploration. Apparently, the nearby presence of exploration introduces technological novelty that may also be beneficial to rejuvenate the larger and mature part of the firm's technology portfolio represented by exploitation activities.

\subsection{Theoretical implications}

Previous research has presented a range of organizational solutions to achieve a balance between exploitation and exploration (O'Reilly and Tushman, 2013). These include structural separation, temporal cycling through periods of exploration and exploitation, building an organizational context in which teams or individuals are motivated to divide their time between exploration and exploitation, and engaging in inter-firm activities such as alliances and acquisitions. Although firms increasingly organize their exploratory and exploitative activities in a geographically dispersed manner, prior ambidexterity research has ignored the geographical dimension when modelling the ambidexterity-performance relationship. This is surprising, as existing research on international knowledge sourcing has pointed at its relevance (e.g. Alcacer \& Chung, 2007; Ko \& Liu, 2015; Rosenkopf \& Almeida, 2003). This literature stream suggests that geographical proximity enables knowledge spillovers in local innovation systems, which in turn facilitates learning and may result in a higher degree of technological performance. Firms may not only benefit from inter-organizational spillovers, but also from intra-organizational spillovers between exploration and exploitation activities that are performed in geographic proximity.

Our study contributes by examining the performance impact of the degree to which technology exploration and exploitation activities are pursued in spatial proximity. Our findings underscore the relevance of including a geographic dimension in the analysis to better understand how firms can reach an effective balance between both technology activities. Indeed, where previous contributions stressed the importance of achieving integration via the role and behavior of senior 
management and cross-unit task forces (e.g. O’Reilly \& Tushman, 2004 \& 2011; Jansen et al., 2010); our findings point to a complementary, bottom-up, mechanism - localized intra-firm knowledge transfers and spillovers - to achieve synergies between exploitation and exploration. As achieving synergies is likely to be key in order for ambidexterity to become sustainable (Van Looy et al., 2005), future conceptualizations of organizational structures to support ambidexterity might benefit from paying sufficient attention to integrative mechanisms, including spatial proximity of exploration and exploitation.

\subsection{Managerial implications}

Our findings might enable managers to assess whether their current technological performance can be improved by considering the geographical dispersion of their firms' exploratory and exploitative activities. While it is clear that firms already enact geographical dimensions of organizing, our findings can inform the decision making process on firms' existing and future organizational set-up of exploration and exploitation by highlighting the importance of spatial proximity between technology exploration and exploitative activities. An illustrative example is the development of the Nespresso coffee system in the late 1980s and early 1990s, by the Nestlé company. To develop, produce and market the new Nespresso system, Nestlé created a separate 100\%-owned Nestlé affiliate called Nespresso, but located it across the street from the main Nestlé organization (Markides and Oyon, 2010; Miller and Kashani, 2003). Whereas the structural separation allowed for the installment of different processes, cultures and mindsets, the spatial proximity allowed Nestlé to enact synergies between the traditional Nescafé and the new Nespresso coffee businesses.

It goes without saying that benefits stemming from internal spillovers and knowledge transfers between technology exploration and exploitation activities need to be considered in conjunction with benefits arising from locating (new) development activities in regions with specific expertise that may be new to the firm (Lecocq et al., 2011; Belderbos et al. 2014). Managers are also well advised to consider that technology relatedness (Breschi, 2003; Leten et al., 2007 \& 2016) can play an important role in effective entry and performance in new technology fields. Explicit considerations of these factors will result in more informed and hence more effective corporate decision making regarding the composition and location of exploratory and exploitative R\&D activities.

\subsection{Limitations and avenues for future research}

Our research is subject to limitations. We highlight four particular issues that may inspire future research. First, our analysis of spatial ambidexterity has focused on ambidexterity in technology development. Technology development is an important aspect of ambidextrous organizing and firms' sustainable competitive advantage, and it is well conceivable that the benefits of cross-fertilization and knowledge exchange in relationship with spatial proximity are most pronounced for firms' technological activities. We suggest that future research employs broader conceptualizations of ambidexterity with exploitation and exploration activities extending to 
non-technological activities such as marketing, in order to investigate to what extent our findings can be replicated in such settings.

Second, this study relies on patent data that measures technological activity of an exploratory and exploitative nature. Each patent was classified as explorative or exploitative. We observed a very high correlation between two dependent variables: exploitation performance and technological performance. This relates to the fact that the majority of the patents were exploitative (92\%). Exploration patents only accounted for $8 \%$ of all patents. While it can be expected that firms will exhibit more exploitation compared to exploration, future research can apply other (non-patent) data to examine spatial ambidexterity.

Third, this article examined the importance of spatial ambidexterity using data for the period 1995-2003. Although we think that the relationship between spatial ambidexterity and firms' technological performance is generic and not strongly depended on the time period under study, we consider it an useful avenue for further research to examine whether the effect of spatial ambidexterity has strengthened or weakened in more recent time periods.

Fourth, our findings are based on data for large R\&D intensive firms and cannot be easily generalized to small firms, which often achieve ambidexterity by alternating between focused periods of exploration and exploitation (Brown and Eisenhardt, 1997).

Fifth, our research has focused on the role of spatial proximity but did not examine the role of other types of organizational configurations, in particular the degree of structural separation between exploitation and exploration within or across regions, and inter-organizational configurations that might reflect patterns of ambidexterity as well. Efforts to address these dimensions would benefit from the availability of fine-grained data regarding organizational structures and R\&D alliances. Our current data compile technological activities without differentiating between organizational units of the firm in a region and the role that for instance mergers and acquisitions and technology alliances play in the changing configuration of exploitation and exploration. Extending analysis in these directions may imply the introduction of survey efforts (to measure organizational structures) and the combination of multiple databases that contain information on patents, mergers and acquisitions and technology alliances. The build-up of such data platforms would allow researchers to examine the interplay of different separation and integration mechanisms and to identify the optimal organizational configurations for reaching organizational ambidexterity. 


\section{References}

Abernathy, W. 1991. The productivity dilemma. Baltimore: John Hopkins University Press.

Adler, P. S., Goldoftas, B., \& Levine, D. I. 1999. Flexibility versus efficiency? A case study of model changeovers in the Toyota production system. Organization Science, 10(1): 43-68.

Ahuja, G., \& Lampert, C. M. 2001. Entrepreneurship in the large corporation: A longitudinal study of how established firms create breakthrough inventions. Strategic Management Journal, 22(6-7): 521-543.

Alcacer, J., \& Chung, W. 2007. Location strategies and knowledge spillovers. Management Science, 53(5): 760776.

Allen, T. 1977. Managing the flow of technology. Cambridge (MA): MIT Press.

Belderbos, R., Faems, D., Leten, B., \& Van Looy, B. 2010. Technological Activities and Their Impact on the Financial Performance of the Firm: Exploitation and Exploration within and between Firms. Journal of Product Innovation Management, 27(6): 869-882.

Belderbos, R., Lokshin, B. \& Sadowski, B. 2015. The Returns to Foreign R\&D. Journal of International Business Studies, 46(4): 491-504.

Belderbos, R., Van Roy, V., Leten, B., \& Thijs, B. 2014. Academic research strengths and multinational firms' foreign R\&D location decisions: evidence from $\mathrm{R} \& \mathrm{D}$ investments in European regions. Environment and Planning A, 46(4): 920-942.

Benner, M. J., \& Tushman, M. L. 2003. Exploitation, exploration, and process management: The productivity dilemma revisited. Academy of Management Review, 28(2): 238-256.

Breschi, S., Lissoni, F., \& Malerba, F. 2003. Knowledge relatedness in firm technological diversification. Research Policy, 32(1): 69-87.

Brown, S. L., \& Eisenhardt, K. M. 1997. The art of continuous change: Linking complexity theory and time-paced evolution in relentlessly shifting organizations. Administrative Science Quarterly, 42(1): 1-34.

Burns, T. E., \& Stalker, G. M. 1961. The management of innovation. London: Tavistock.

Cameron, C. A., \& Trivedi, P. K. 1998. Regression analysis of count data. Cambridge: Cambridge University Press.

Cao, Q., Gedajlovic, E., \& Zhang, H. P. 2009. Unpacking Organizational Ambidexterity: Dimensions, Contingencies, and Synergistic Effects. Organization Science, 20(4): 781-796.

Deyle, H. G., \& Grupp, H. 2005. Commuters and the regional assignment of innovative activities: A methodological patent study of German districts. Research Policy, 34(2): 221-234.

Duncan, R. 1976. The ambidextrous organization: Designing dual structures for innovation. In R. H. Killman, L. R. Pondy, \& D. Sleven (Eds.), The management of organization, 1: 167-188. New York: North Holland.

Fang, C., Lee, J., \& Schilling, M. A. 2010. Balancing Exploration and Exploitation Through Structural Design: The Isolation of Subgroups and Organizational Learning. Organization Science, 21(3): 625-642.

Fung, M. K. 2002. Technological opportunity and economies of scale in research productivity: A study on three global industries. Review of Industrial Organization, 21(4): 419-436.

Ghemawat, P., \& Costa, J. 1993. The organizational tension between static and dynamic efficiency. Strategic Management Journal, 14(Winter): 59-73.

Gibson, C. B., \& Birkinshaw, J. 2004. The antecedents, consequences, and mediating role of organizational ambidexterity. Academy of Management Journal, 47(2): 209-226.

Gupta, A. K., Smith, K. G., \& Shalley, C. E. 2006. The interplay between exploration and exploitation. Academy of Management Journal, 49(4): 693-706.

Hall, B. H., Jaffe, A., \& Trajtenberg, M. 2005. Market value and patent citations. Rand Journal of Economics, 36(1): 16-38.

Hargadon, A. B. 1998. Firms as knowledge brokers: Lessons in pursuing continuous innovation. California Management Review, 40(3): 209-227.

He, Z. L., \& Wong, P. K. 2004. Exploration vs. exploitation: An empirical test of the ambidexterity hypothesis. Organization Science, 15(4): 481-494.

Heyden, M., Oehmichen, J., Nichting, S., \& Volberda, H. 2015. Board heterogeneity and exploration-exploitation: The role of institutionally adopted board model. Global Strategy Journal, 5(2): 154-176.

Jaffe, A., \& Lerner, J. 2004. Innovation and its Discontents: How our Broken Patent System is Endangering Innovation and Progress, and What to do About it. Princeton: Princeton University Press. 
Jansen, J., F. Van den Bosch, \& Volberda, H. 2006. Exploratory innovation, exploitative innovation, and performance: Effects of organizational antecedents and environmental moderators. Management Science, 52(11): 1661-1674.

Jansen, J.F., Van den Bosch, \& Volberda, H. 2010. Top Management Team Advice Seeking and Exploratory Innovation: The Moderating Role of TMT Heterogeneity. Journal of Management Studies, 47(7): 13431364.

Khan, M., \& Dernis, H. 2006. Global Overview of Innovative Activities from Patent Indicators Perspective, Science, Technology and Industry Working Papers Number 2006/3. Paris: Organisation for Economic Cooperation and Development (OECD).

Ko, W. W., \& Liu, G. 2015. Understanding the Process of Knowledge Spillovers: Learning to Become Social Enterprises. Strategic Entrepreneurship Journal, 9(3): 263-285.

Kodama, F. 1992. Technology fusion and the new research-and-development. Harvard Business Review, 70(4): 70-78.

Lahiri, N. 2010. Geographic Distribution of R\&D Activity: How Does It Affect Innovation Quality? Academy of Management Journal, 53(5): 1194-1209.

Lavie, D., Kang, J., \& Rosenkopf, L. 2011. Balance Within and Across Domains: The Performance Implications of Exploration and Exploitation in Alliances. Organization Science, 22(6): 1517-1538.

Lecocq, C., Leten, B., Kusters, J. \& Van Looy, B. 2012. Do firms benefit from being present in multiple technology clusters? An assessment of the technological performance of biopharmaceutical firms. Regional Studies, 46(9): 1107-1119.

Leten, B., Belderbos, R., \& Van Looy, B. 2007. Technological diversification, coherence, and performance of firms. Journal of Product Innovation Management, 24(6): 567-579.

Leten, B., Belderbos, R., \& Van Looy, B. 2016. Entry and technological performance in new technology domains: Technological opportunities, technology competition and technological relatedness. Journal of Management Studies, 53(8), 1257-1291.

Leten, B., Landoni, P., \& Van Looy, B. 2014. Science or graduates: How do firms benefit from the proximity of universities? Research Policy, 43(8): 1398-1412.

Levinthal, D. A., \& March, J. G. 1993. The myopia of learning. Strategic Management Journal, 14: 95-112.

Levitt, B., \& March, J. G. 1988. Organizational Learning. Annual Review of Sociology, 14: 319-340.

March, J. G. 1991. Exploration and Exploitation in Organizational Learning. Organization Science, 2(1): 71-87.

Markides, C. \& Oyon, D. 2010. What to do against disruptive business models (when and how to play 2 games at once)? Sloan Management Review, 51(4): 24-31.

McGrath, R. 2001. Exploratory learning, innovative capacity and managerial oversight. Academy of Management Journal, 44(11): 118-131.

Miller, J. \& Kashani, K. 2003. Innovation and renovation: The Nespresso story. IMD case study no. 5-0543.

Mitchell, W., \& Singh, K. 1992. Incumbents' use of pre-entry alliances before expansion into new technological subfields of an industry. Journal of Economic Behavior and Organization, 18(3): 347-372.

Moncada-Paterno-Castello, P., Vivarelli, M., \& Voigt, P. 2011. Drivers and impacts in the globalization of corporate R\&D: an introduction based on the European experience. Industrial and Corporate Change, 20(2): 585-603.

Nelson, R. and Winter, S. 1982. An evolutionary theory of economic change. Massachusetts and London, England: Harvard University Press.

Nerkar, A., \& Roberts, P. 2004. Technological and product-market experience and the success of new product introductions in the pharmaceutical industry. Strategic Management Journal, 25(8-9):779-799.

Nonaka, I., 1994. A dynamic theory of organizational knowledge creation. Organization Science, 5(1): 14-37.

OECD. 2007. Intellectual assets and international investment: A stocktaking of the evidence. Report to the OECD Investment Committee DAF/INV/WD(2007)6, Paris, OECD.

O’Reilly, C. A., \& Tushman, M. L. 2004. The Ambidextrous Organization. Harvard Business Review, 82(4): 74-81.

O’Reilly, C. A., \& Tushman, M. L. 2011. Organizational Ambidexterity in Action: How Managers Explore and Exploit. California Management Review, 53(4): 5-22.

O’Reilly, C. A., \& Tushman, M. L. 2013. Organizational Ambidexterity: Past, Present, and Future. Academy of Management Perspectives, 27(4): 324-338. 
Pakes, A., \& Griliches, Z. 1984. Estimating Distributed Lags in Short Panels with an Application to the Specification of Depreciation Patterns and Capital Stock Constructs. Review of Economic Studies, 51(2): 243-262.

Penner-Hahn, J., \& Shaver, M. 2005. Does international research and development increase patent output? An analysis of Japanese pharmaceutical firms. Strategic Management Journal, 26(2): 121-140.

Phene, A., Fladmoe-Lindquist, K. \& Marsh, L. 2006. Breakthrough innovations in the U.S. biotechnology industry: the effects of technological space and geographic origin. Strategic Management Journal, 27(4): 369-388.

Polanyi, M. 1966. The tacit dimension. New York: Doubleday Anchor.

Prahalad C. K., \& Hamel, G. 1990. The core competence of the corporation. Harvard Business Review, 68(3): 79-91.

Quillen, C., \& Webster, O. 2001. Continuing patent applications and performance of the US patent office. Federal Circuit Bar Journal, 11(1): 1-21.

Quintana-Garcia, C., \& Benavides-Velasco, C. A. 2008. Innovative competence, exploration and exploitation: The influence of technological diversification. Research Policy, 37(3): 492-507.

Rosenkopf, L., \& Almeida, P. 2003. Overcoming local search through alliances and mobility. Management Science, 49(6): 751-766.

Rosenkopf, L. \& Nerkar, A. 2001. Beyond local search: Boundary-spanning, exploration, and impact in the optical disk industry. Strategic Management Journal, 22(4): 287-306.

Siggelkow, N., \& Levinthal, D. A. 2003. Temporarily divide to conquer: Centralized, decentralized, and reintegrated organizational approaches to exploration and adaptation. Organization Science, 14(6): 650669.

Stettner, U., \& Lavie, D. 2014. Ambidexterity under scrutiny: Exploration and exploitation via internal organization, alliances and acquisitions. Strategic Management Journal, 35(13): 1903-1929.

Todo, Y., \& Shimizutani, S. 2008. Overseas R\&D activities and home productivity growth: Evidence from Japanse firm-level data. Journal of Industrial Economics, 56(4): 752-777.

Trajtenberg, M. 1990. A Penny for Your Quotes - Patent Citations and the Value of Innovations. Rand Journal of Economics, 21(1): 172-187.

Tushman, M. L., \& O’Reilly, C. A. 1996. Ambidextrous Organizations: Managing Evolutionary and Revolutionary Change. California Management Review, 38(4): 8.

Tushman, M., Smith, W.K., Wood, R.C., Westerman, G. \& O’Reilly, C. 2010. Organizational designs and innovation systems. Industrial and Corporate Change, 19(5): 1331-1366.

UNCTAD. 2005. World Investment Report 2005, New York: United Nations.Uotila, J., Maula, M., Keil, T., \& Zahra. S. 2009. Exploration, exploitation and financial performance: Analysis of S\&P 500 corporations. Strategic Management Journal, 30(2): 221-231.

Van Looy, B., Martens, T., \& Debackere, K. 2005. Organizing for Continuous Innovation: On the Sustainability of Ambidextrous Organizations. Creativity and Innovation Management, 14(3): 208-221.

Van Pottelsberghe de la Potterie, B., \& François, D. 2006. The cost factor in patent systems, EPO working papers CEB 06-002.

von Hippel, E. 1994. Sticky information and the locus of problem solving: Implications for innovations. Management Science, 40(3), 429-439.

Zollo, M., \& Winter, S. G. 2002. Deliberate learning and the evolution of dynamic capabilities. Organization Science, 13(3): 339-351. 


\section{Chapter 4}

\section{Does market leadership require technological leadership in emerging markets?'}

1 This chapter is based on the working paper: Geerts, A., Blindenbach-Driessen, F., Visscher, K., de WeerdNederhof, P.C. \& Van Looy, B. (2019). Does market leadership require technological leadership in emerging markets? Paper presented at 26th International Product Development Management Conference, Leicester (United Kingdom), June 9-11 2019. 


\section{Abstract}

While it is often assumed that capturing market share requires/builds on technological innovation, the relationship between market leadership and technological leadership has not been widely explored. Does market leadership coincide with technological leadership? Do technological activities enable firms to become market leaders in an emerging high-tech market? While consensus exists about the necessity for firms to engage in both R\&D-based exploration and exploitation activities, little is known about whether a balanced technological portfolio is related to market leadership in an emerging market. This exploratory study provides insights in the relation between market leadership and technological leadership in an emerging hightech market. Empirical evidence for 17 firms that cover the global emerging market of ADSL technology shows that the relationship between market leadership and technological leadership is complex and nuanced. We study the first six years of the emerging high-tech market. Relying on patent data from 1990 to 2003 and market data from 1998 to 2003, this study reveals that without patents in the core and complementary technologies, one cannot become a market leader. However, the reverse does not automatically hold true. Having more or industry-novel patents does not guarantee market leadership. The results also show that market leadership does not depend on displaying a strong balance between technology exploration and exploitation. What seems to matter more is to have a consistent balanced technological portfolio. While there is a relation between technology and market share, market success cannot be reduced to success in technology development. Technology is a necessary but not sufficient condition for market success. This study contributes to our knowledge about the role of technology in market leadership and the relevance of combining exploration and exploitation efforts in an emerging high-tech market. 


\section{Introduction}

One of the important metrics for top managers is market share (Edeling \& Himme, 2018). The market share-performance relationship is widely studied. In contrast, the market share-technology relationship is much less explored. Market share refers to a firm's monetary-based or volumebased fraction of the total market (Edeling \& Himme, 2018).

Since March's (1991) seminal article "Exploration and exploitation in organizational learning", exploration and exploitation became key concepts in explaining innovation and firm performance. This performance relationship has increasingly been subject of research in leading management journals during the past two decades (e.g. Mathias, McKenny, \& Crook, 2018; O’Reilly \& Tushman, 2013; Raisch, Birkinshaw, Probst, \& Tushman, 2009). Prior studies tend to focus on performance effects at a firm level regardless of a particular market or what other firms do in the same technological field (e.g. Belderbos, Faems, Leten, \& Van Looy, 2010a; He \& Wong, 2004; Mathias et al., 2018; Uotila, Maula, Keil, \& Zahra, 2009).

The need for firms to engage in both exploration and exploitation is also described as the need to be ambidextrous. O'Reilly and Tushman (2013) define organizational ambidexterity as "the ability of an organization to both explore and exploit - with the aim of competing in mature technologies and markets where efficiency, control, and incremental improvement are prized and to also compete in new technologies and markets where flexibility, autonomy, and experimentation are needed" (p. 324). The link between ambidexterity and competing in new technologies and markets has mainly been described in the context of transitions and extensions of existing markets (Tushman \& Oreilly, 1996). Is a balanced technological portfolio, i.e. a portfolio consisting of patents of both an exploratory and exploitative nature, also essential in the context of becoming a market leader in an emerging high-tech market? Following prior insights about the relevance of exploitation and exploration (March, 1991; O'Reilly \& Tushman, 2013), it can be stated that the future will be more favorable for the prepared mind, hence, firms engaging more in exploration up to a certain point - will be more effective. These exploratory activities should occur along the exploitative efforts aimed at insuring the firm's current viability.

Tushman and Oreilly (1996) for example looked at market leadership, but they did not investigate the role patents played for each of the firms that lead these new markets. Others who studied explorative and/or exploitative patents (e.g. Belderbos et al., 2010a; Coombs, Deeds, \& Ireland, 2009; Geerts, Leten, Belderbos, \& Van Looy, 2018), did not look at the impact on capturing leadership in a new market.

As said, the objective of this paper is to shed light on the relation between market leadership and technological leadership in an emerging high-tech market. Moreover, this paper explores whether a balanced technological portfolio enables firms to become market leaders. We do so by examining the patent portfolios and its exploratory and exploitative nature of 17 firms that compose the global ADSL market during its emergence from 1990 to 2003. ADSL technology delineates a particular technology field. As such, examining the ADSL market enables a clear view on the link between a firm's technological activities and market share. 
Relying on descriptive and univariate statistics, we question to what extent market leadership in an emerging high-tech market coincides with technological leadership, related to number of patents, patent quality and novelty. In addition, we examine to what extent a balanced technological portfolio matters to become market leader in an emerging high-tech market.

We use a panel dataset that involves patent applications filed by these firms in the European Patent Office (EPO), United States Patent and Trademark Office (USPTO), Patent Cooperation Treaty (PCT) and ADSL market data.

\section{Theoretical background}

\subsection{Market leadership}

Market leadership has attracted attention from researchers in different areas such as industrial organization, strategic management and technology management. In contrast to the broad range of conceptualizations of technological leadership, consensus exists about the definition of market leadership. The literature defines market leadership as having the largest market share in an industry or a particular market (e.g. Asimakopoulos \& Whalley, 2017; Kato \& Honjo, 2009; Na, Son, \& Marshall, 2007). For example, Kato and Honjo (2009) studied the persistence of market leadership in 374 industries. They identified the market leader in each industry as "the first-ranked firm, based on firm's market shares in the industry" (Kato \& Honjo, 2009, p. 1112).

There is a general agreement that market leadership might result in competitive advantages for a firm (Asimakopoulos \& Whalley, 2017). It comes as no surprise that many firms strive towards obtaining and maintaining a market leadership status. Firms might even prefer to maximize their growth and market share rather than their short-term profit. Kaplan (1994) observed this for example in the case of many Japanese technology firms.

Besides industry-specific characteristics, market leadership is influenced by firm-specific attributes. Tellis and Golder (1996) distinguish five critical success factors for market leadership: vision, persistence, commitment, innovation and asset leverage.

Chesbrough (1999) observed that leading established firms in the Japanese disk drive industry maintained their market leadership to a large extent due to their ability to develop new technologies. Leiponen and Helfat (2010) argue that firms can improve their innovation success if they actively search for broad knowledge in a wide range of technological domains and pursue multiple parallel objectives. Studying leading firms in the European manufacturing sector, an economic report published by the European Commission finds strong support for a positive relationship between technology and product market leadership (Belderbos, Sleuwaegen, \& Veugelers, 2010b).

Studying cycles of technology development, Schmoch (2007) concludes that technology and market activities should be differentiated in a clear way. His research shows that market activities do not necessarily follow the cyclic course of technological activities. The literature describes that the relation between innovation and market leadership can be quite complex as firms for example can lose their market leadership position in the face of new technology development from 
other firms (Cohen, 2010). However, turning technology development into commercial success might depend on more than just possessing the core technological capabilities. Complementary technologies are important too and being able to control the bottleneck asset(s) in the value chain is also relevant to obtain market success (Hu, Kang, \& Wu, 2017; Pisano, 2006; Pisano \& Teece, 2007). While consensus exists about the need for technology development to capture market success in technological sectors, little empirical evidence exists about how important technology leadership is to become market leader.

\subsection{Technological leadership}

"Technology (engineering knowledge) has become an economic engine in technology-based firms" (Granstrand, 1998, p. 466). Should firms become technology leaders in order to capture a large market share in an emerging high-tech market? A review of the literature shows it is important for a firm, industry, region or a country to gain and keep technological leadership, especially in emerging high-tech markets. Technological innovation seems to be a key feature of technological leadership, which is commonly measured through a firm's patents (Belderbos et al., 2010b; Burhan, Singh, \& Jain, 2017; Griliches, 1990).

Several scholars describe technological leadership in terms of technological innovation - for example, having the most patents and creating most of the new products (Drezner, 2001), being an industry pioneer who introduces new production technology (Tang, 2011), dominant players in R\&D (Belderbos \& Somers, 2015), being specialized in terms of technological innovation in a sector or activity (Cantwell \& Janne, 1999) or pioneering the development and application of a particular technology and experiencing attendant competitive advantage (McKenney, Mason, \& Copeland, 1997). Being a pioneer is one of the features of technological leadership according to Tang (2011). Other scholars consider technological leadership as being technical efficient (Bernard, Cantner, \& Westermann, 1996; Chow \& Fung, 1997). Technological leadership is also explained in the literature as a firm's or region's close proximity to the technological frontier (Fontana \& Vezzulli, 2016; Yu, Wu, Zhang, \& Liu, 2016).

The main theoretical framework on technological capabilities and market performance is the resource-based view (RBV) of the firm (Barney, 1996; Wernerfelt, 1984). Firms differ from each other on the basis of their resources. According to the RBV, a firm's strategy should depend on its resources (Wernerfelt, 2005). Leading firms typically possess superior resources (e.g. Asimakopoulos \& Whalley, 2017; Drezner, 2001; Suarez \& Lanzolla, 2005). A crucial type of resources involves $\mathrm{R} \& \mathrm{D}$, technology development or innovations (Granstrand, 1998).

The technological capabilities of a firm are far from easy to develop. Technology development often implies risks due to the required investments in $R \& D$ and frequent uncertainty in terms of outcome. As Teece (2017) explains, a firm's technological capabilities relate to its prior technological activities. Multiple scholars agree that a broad set of technological competencies facilitates continuous improvement and innovation as cross-fertilization effects and synergies might occur (Garcia-Vega, 2006; Granstrand, Patel, \& Pavitt, 1997; Miller, 2006). The concept of 'multi-technology corporations' emerged as a new name for large firms (Granstrand et al., 1997). 
However, a too broad technological portfolio might be harmful for firm performance (Kim, Lee, \& Cho, 2016; Leten, Belderbos, \& Van Looy, 2007). Excessive technological diversification can hamper firms from arriving at economies of scale and induce high coordination and integration costs (Leten et al., 2007).

Many firms seek to protect their technology-related knowledge assets such that they can gain and maintain a competitive advantage in the industry. Practitioners and scholars have already paid a lot of attention to how to build protective barriers in the form of legal protection and other strategies such as complementary assets (Pisano \& Teece, 2007; Scotchmer, 1996; Stringham, Miller, \& Clark, 2015).

This chapter focuses on patents as an indicator for a firm's technological position. A patent is defined as "a temporary property right on an invention" (Rockett, 2011, p. 317). Patents shape a kind of a protected economic environment in which firms can develop their knowledge-assets into commercially viable products (Jaffe \& Lerner, 2006). A firm's technology-related knowledge assets and innovation efforts are often examined through patents (Burhan et al., 2017; Rockett, 2011). Patents are particularly important in creating the nature of competition in product and technology markets. (Galasso \& Schankerman, 2018).

Due to the cumulative nature of technologies, a patent on a core technology can be seen as the basis for new innovations (Galasso \& Schankerman, 2018). Core technology is different from complementary technologies. Core technology refers to the most important technology (Granstrand \& Holgersson, 2013), while complementary technologies are technologies of which the know-how or capabilities can be used for leveraging the core technology (Teece, 1986).

Relying on technology and market data of 250 leading firms in EU manufacturing industries, Belderbos et al. (2010b) find a positive relationship between a firm's share of patents and the share in its sector's total EU production. The results suggest that technological leadership is less important for incumbents to sustain their production leadership, compared to new leading entrants. However, technological leadership seems to be important for new leading entrants in order to obtain a stronger production leadership. In addition, technological leadership is found to be more important in high-tech sectors compared to low- or medium-tech sectors. Focusing on a single emerging market within the telecommunications equipment sector, this research addresses the following questions:

Research question 1. To what extent does market leadership in an emerging high-tech market requires technological leadership in the core technology?

Research question 2. To what extent does market leadership in an emerging high-tech market requires technological leadership in complementary technologies?

\subsection{Exploration, exploitation and the importance of a balanced portfolio}

Technological activities can have an exploratory or exploitative nature. According to March (1991), exploration refers to organizational behavior characterized by search, discovery, experimentation and risk taking. The bottom line of exploration is experimentation with new alternatives. Exploitation involves organizational behavior characterized by refinement, choice, efficiency, 
selection and implementation. The core of exploitation is the refinement and extension of existing competences, technologies, and paradigms. March suggests that firms need to be committed to both exploration and exploitation. Firms who exclusively focus on exploration will enhance the ability to renew its knowledge base, but it can result in experiencing high costs of experimentation without gaining many benefits. On the opposite, firms who concentrate solely on exploitation may enhance short-term performance, but are likely to find themselves trapped in suboptimal stable equilibria, not able to respond adequately to environmental changes (March, 1991).

Throughout the years, the exploration-exploitation framework gradually evolved from focusing on organizational behavior to the subject of innovation (Wilden, Hohberger, Devinney, \& Lavie, 2018). Whereas March examined exploration and exploitation from the context of behavioral theory of the firm, his initial focus on organizational behavior progressed towards explaining innovation and firm performance.

"R\&D-based exploration and exploitation are necessary in order for firms to have sustainable competitive advantage" (Swift, 2016, p. 1688). However, carrying out both types of activity is far from easy (Mathias et al., 2018; Swift, 2016).

To study exploration, exploitation and a balance between both empirically, an increasing number of scholars apply patents as a proxy for organizational learning (e.g. Belderbos et al., 2010a; Geerts et al., 2018; Hu, Wu, Lee, \& Lu, 2014; Lee \& Huang, 2012). These studies have shown that firms that combine exploration and exploitation activities, in other words, firms that are ambidextrous are more profitable.

Others, like Tushman and O'Reilly (1996) have shown how firms that pursued both exploration and exploitation obtained and maintained their market leadership in among others the semiconductor industry. However, they did not look at the patent portfolios of the involved firms. We add to their research by investigating if a balance between exploration and exploitation in a firm's research activities enables firms to successfully enter a new market. Besides looking at the balance of the patent portfolio, we also assess whether novelty - as related to the core technology - is an enabling factor in capturing market leadership in an emerging high-tech market. We therefore examine the following research questions:

RQ 3: To what extent does a balanced technological portfolio enable market leadership in an emerging high-tech market?

RQ 4: To what extent does novelty in a firm's core technological activities enable market leadership in a new emerging high-tech market?

\section{Methods}

\subsection{Research setting and sample}

The telecommunications equipment industry is subject to continuous technological change and a significant impact of the regulatory environment. This has led to a major restructuring of the global industry over the past decades. Since the 1970s, we observe considerable entry and exit of 
firms, together with significant changes in sizes of incumbent firms. The US telecommunications equipment sector experienced the deregulation of the telephone services and a split of the Bell System in the 1980s. This allowed for competition in the telecommunications equipment industry as government imposed entry barriers were removed (Guite, 1987). A similar evolution took place in the European telecommunications equipment industry (Liikanen, 2001). The global industry initially experienced radical innovation with the function of integrated circuit technology that enables digital switching of telephone calls. The digitalization of the telephone networks in the 1970s and early 1980s was mainly followed by technology development aimed at reconfiguration of components and changes such that the telecom equipment could address a wide range of user needs. Technological developments followed one another. There were no long periods of stable design convergence (Dowling \& McGee, 1994).

In the early 1990's, the rise of the ADSL technology, led to the development of a new market segment in the telecommunication equipment industry. ADSL became the most common technology for internet access offered to home users. Appendix 1 shows a brief history of digital data transport towards the ADSL solution. The original idea of ADSL dates back to 1979, when Cioffi at Stanford University first introduced calculations that enable more capacity by using copper wire, and to the early 1980s, when Lechleider focused on asymmetry as an additional way to increase capacity (of digital copper subscriber lines) in the lab of Bellcore - Bell Communications Research (Goralski, 2002). It was not until the early 1990s that established companies jumped on the bandwagon to further develop the scientific insights about ADSL technology into a commercial product after in-company experiments confirmed the potential of copper wires combined with DSL technology. The technology cycle of ADSL seems to have started with what Schmoch (2007) describes as 'science or technology push', followed by 'market-pull' forces.

ADSL is subject to standard specification, which is forced by an official standardization institute and should be applied by all industry players in order to ensure inter-operability . Firms had to comply with the imposed ADSL standard in their technology development and commercial objectives in order to be compatible (DeLacey, Herman, Kiron, \& Lerner, 2006). ${ }^{22}$ The ADSL standard was chosen after testing different ADSL prototypes, developed by competing firms in the early 1990s.

This paper focuses on the 17 firms that composed the emerging worldwide ADSL technology market in the 1990's: ADC Telecommunications, Alcatel, Cisco, ECI Telecom, Ericsson, Lucent, NEC, Nokia, Nortel, Orckit, Pairgain, Paradyne, Samsung Electronics, Siemens, Sumitomo Electric, Utstarcom and Westell. These firms were selected on the basis of the global ADSL market reports of an independent international market research corporation, Dell'Oro Group. ${ }^{23}$

22 The American National Standard Institute (ANSI) released the standard specification of ADSL in 1995, T1.413. This standardization was then also imposed by the International Telecommunications Union (ITU) and the European Telecommunications Standard Institute (ETSI) Chen, W. Y. 1999. The development and standardization of asymmetrical digital subscriber line. Ieee Communications Magazine, 37(5): 68-72.

Alcatel bought the market reports from Dell'Oro Group and made them available for this study. 


\subsection{Data and method}

All firm level data are collected on a consolidated level: the parent firm and its consolidated (majority-owned) subsidiaries. We used lists of subsidiaries included in corporate annual reports and $10-\mathrm{K}$ reports filed with the SEC in the US. To collect indicators of firm's technological activities we used patent data from the European Patent Office (EPO), United States Patent and Trademark Office (USPTO) and Patent Cooperation Treaty (PCT). PCT patents are patents that are filed in the World Intellectual Property Organization (WIPO).

We chose for patent applications (rather than grants) as this data provides a better indication of technological activities of a more explorative nature (Geerts et al., 2018). All patent data are retrieved from the October 2014 version of the EPO Worldwide Patent Statistical Database (PATSTAT). Although many scholars focus on one patent office, this study involves patents applied for in three common patent offices in order to have a more complete view on the technological activities of the involved firms. We took into account the presence of patent families in order to correct for home biases and to get a better estimation of the impact of a firm's technological activities (Bakker, Verhoeven, Zhang, \& Van Looy, 2016). A patent family is defined as the set of patents filed in several countries, which are related to each other by one or several common priority fillings (OECD, 2009). This research applies the frequently used patent family approach of DOCDB which means that related patent applications are considered that are covering the same technical content (EPO, 2017).

The data include all patents related to the ADSL technology, applied for by the 17 sample firms that composed the new ADSL market until stages of market maturity arose in 2003 (i.e. ADSL patent applications from 1990-2003). In order to identify the ADSL patents, a search key was applied based on technology classes and key words in the abstract of the patents (Dekeyser, 2009). Before applying, the search key was validated by practitioners in the field of ADSL technology. A total of 3,759 unique ADSL patent applications are identified across the 17 firms. This enables us to explore whether technological leadership in ADSL coincides with market leadership. As the number of citations that a patent receives (i.e. forward citations) is a valuable indicator for the quality and impact of the patent (Jaffe \& de Rassenfosse, 2017; Trajtenberg, 1990), citation data of each patent is included in measuring technological leadership. The ADSL market data are provided by the market reports of an international market research corporation. These reports involve firm-level data from 1998-2003, as the first ADSL end-to-end product entered the market in 1997.

We examine the relationship between technological leadership, technological activities of an exploratory and exploitative nature and market share of the 17 firms in the ADSL market, using a panel dataset (1995-2003). Although the market data encompass the period 1998-2003, our dataset goes back to 1995 as these three years in advance include influential technological activities that occurred before the market launch of ADSL. Technological leadership and a balance between exploration and exploitation in a firm's patent portfolio are studied at two levels: core technology (ADSL) and complementary technologies (electrical engineering). The ADSL patent portfolio of the sample firms includes 3,759 unique patent applications for the period 1990-2003. The electrical engineering portfolio involves 164,566 unique patent applications. 
Each patent involves one or more technology classes. For example, ADC Telecom's patent EP 269722 involves classes H04M and H04Q. Relying on technology class information from the International Patent Classification System (IPC), all patents are classified as an explorative or exploitative patent based on IPC4-digit levels. Following prior research (Belderbos et al., 2010a; Geerts et al., 2018), a patent is assigned to be explorative when it is located in a technology class that is new or unfamiliar to the firm (i.e. a technology class in which the firm has no prior experience). A technology class is defined as new to a firm in year $t$, if the firm (i.e. firm subsidiaries in year t) did not patent in the technology class during the past five years ( $t-5$ to $t-1)$. A five-year time window is considered appropriate as technological knowledge typically evolves quick, losing most of its technical and economical relevance within five years (Ahuja \& Lampert, 2001; Hall, Jaffe, \& Trajtenberg, 2005). As a technology domain is likely to remain relatively new and unexplored for the firm immediately after the firm becomes involved in it, a technology class keeps its explorative status for a period of three consecutive years (Belderbos et al., 2010a). 97,2 \% of the ADSL patents are exploitative while $2,8 \%$ of the ADSL patents are explorative. For the electrical engineering patents, $96,9 \%$ is classified as exploitative while $3,1 \%$ is classified as explorative.

The research questions are examined through the use of descriptive statistics and univariate panel data analysis. Analyses of covariance (ANCOVA) are applied in SPSS with a one-way between subjects design in which firm is included as fixed factor. Like multiple linear regression analysis, this technique allows to examine the effect of different variables of interest. The ANCOVA - robust, even if assumptions for regular regression analysis are not entirely met - examines the effect on market share while comparing the firms (Brace, Kemp, \& Snelgar, 2006; Wilcox, 2007).

\subsection{Variables}

Market share. The dependent variable in this study is the annual market share (1998-2003) of the firms that are active in the worldwide ADSL market from emergence of the market until the market became mature. Market share data involve the sold ADSL ports, in \%. The overall number of ports grows for all firms in this period. The market share shows the relative growth of the companies compared to the other players in the market. This study examines three variations of the dependent variable. First, a simultaneous approach in which the technological activities (cumulative) of the firm are analyzed in relation to the market share they achieved in the same year. Second, an approach that moves market share one year forward in relation to the technological activities of the firm (market share lead, $y+1$ ). Third, a variation in which market share is delayed with one year (market share lag, y-1). This allows us to examine if technology follows market or market follows technology, i.e. the pull and push forces of both.

Technological leadership - ADSL patents. Drezner (2001) described technological leadership as having the most patents and creating most of the new products. Belderbos \& Somers (2015) defined technological leaders as dominant players in $R \& D$. In line with these authors, we define technological leadership as possessing the highest number of patents or the most valuable patent stock. This variable is measured in two ways for ADSL patents: by simple patent counts and citation-weighted patent counts, involving all ADSL patents in the period 1990-2003. The number 
of patent applications has been frequently applied as an indicator for technological performance (e.g. Leten et al., 2007). However, as simple patent counts give no indication about the value or quality of the patent stock, citation-weighted patent counts are also used in this study (Hall et al., 2005; Trajtenberg, 1990). Citation-weighted patent counts are obtained by computing the forward citations, i.e. the number of times that each patent (family) has been cited in consecutive patents, in a fixed time window of 5 years. This number is then used to compute weighted patent counts by year. A depreciation rate of $15 \%$ is applied.

Technological leadership - Electrical engineering patents. Based on the Fraunhofer35 classification (Schmoch, 2008), all patents belonging to the field of electrical engineering are identified as complementary technologies of ADSL and counted. The field of electrical engineering is considered to be a good proxy for complementary technological assets as this field encompasses all technology classes that relate to the ADSL core technology.

Balanced portfolio - Electrical engineering. Balanced portfolio measures to which extent firms are simultaneously active in both technology exploration and exploitation. A high value of balanced portfolio indicates a strong balance, where similar levels of exploratory and exploitative patents exist, while a lower value indicates a focus on one of both activities and a lesser apparent balance. In this study, a balanced portfolio is measured by an indicator which consists of the product of the relative share of explorations patents and the relative share of exploitation patents in a company's patent portfolio. If a company has 10 patents of which 3 are exploration patents, the balanced portfolio value equals $3 / 10$ i.e. $30 \%$ multiplied by $7 / 10$, i.e. $70 \%$. The end result then is 30 multiplied by 70 , which equals to 2,100 . The balanced portfolio is calculated on the level of the firm's electrical engineering patent portfolio.

Exploration share ADSL. There are firm-level differences in a firm's focus on technology exploration (Geerts et al., 2018). The exploration orientation of a firm indicates the relative importance that it attaches to exploration (Heyden, Oehmichen, Nichting, \& Volberda, 2015). A firm's share of exploration patents in ADSL is measured as the share of exploration patents in the total ADSL patents. This variable, like the following three variables, is an indicator for novelty. All novelty variables take into account a firm's ADSL technology development from the first patent application up to and including 2003. As Utterback (1974) explained, there might be a time lag of 8-15 years between technical knowledge and real innovations to occur. "Assessing whether something is novel implies comparing to what existed before" (Verhoeven, Bakker, \& Veugelers, 2016, p. 710).

New Functionality ADSL. This novelty measure assesses if a new combination of technology classes is built. A patent has new functionality when it contains at least one pair of IPC classes that were previously not connected (Verhoeven et al., 2016). From the moment a firm has the first patent in the ADSL field that combines for example IPC4-classes H04J and G06F, a score of 1 is assigned to that firm.

New Originality ADSL. This indicator identifies a patent as new in its origins if it makes a combination between its own IPC code and IPC code from its referenced patents that did not exist in the years prior to the application year of the patent (Verhoeven et al., 2016). If a firm has a patent that is novel in originality, a score of 1 is assigned to that firm. 
New Impact ADSL. This indicator measures technological impact, or the extent to which the focal invention serves as prior art for further follow-on inventive activity (Verhoeven et al., 2016). The number of forward citations are taken into account. If a focal patent is the first to be cited by patents that belong to for example IPC4-classes H04J and G06F, this firm scores 1 on new impact ADSL.

\section{Results}

The descriptive statistics and correlations between the dependent and independent variables are shown in table 4-1. There is a weak to moderate positive significant correlation between the number of ADSL patents, in terms of quantity $(r=.37)$ and quality $(r=.33)$, and ADSL market share. No significant correlations exists between the number of patents in electrical engineering and ADSL market share. There is no significant correlation between the balanced nature of ADSL technology development and ADSL market share. The balanced nature of technological activity in the adjacent technologies, belonging to the field of electrical engineering, shows a weak negative correlation with ADSL market share. There seems to be no relationship between the indicators for novelty in a firm's ADSL technological activity and ADSL market share.

Following these general descriptive statistics, the results of more in-depth analyses provide further insights about the technology leadership-market leadership relation in an emerging hightech market.

\subsection{Market leadership and technological leadership}

Table 4-2 exhibits a ranking of the 17 firms that composed the worldwide ADSL market in its emerging phase. Alcatel enters the market in a market leadership position and succeeds in maintaining its position for at least six years. While Alcatel retains its leadership status, all other firms experience a dynamic pattern in their market share positions from being ranked second to a low market share position a few years later. For example, Siemens enters the market in 2000 with an almost nonexistent market share of $0,2 \%$. The company jumps to a second position in 2001, capturing a market share of $11 \%$. In the following two years, Siemens loses its position and drops to a market share of $5 \%$. Only Utstarcom is able to increase its market share to $7 \%$ over the last 3 years. NEC and Sumitomo Electric enter late and win market share, but seem to be losing their market position after 2002. Although Ericsson also actively pursued technology development in ADSL with the purpose of commercializing this new technology for Internet access, the company never succeeded in capturing more than $2 \%$ of the emerging market. Cisco, Paradyne, Nortel, ADC and Pairgain, are all early players that are not able to maintain their position in the market and lose to latecomers. Nokia participates as a small player, till it drops out in 2003. Samsung rises steadily over the first years, but is not able to sustain that growth either. 


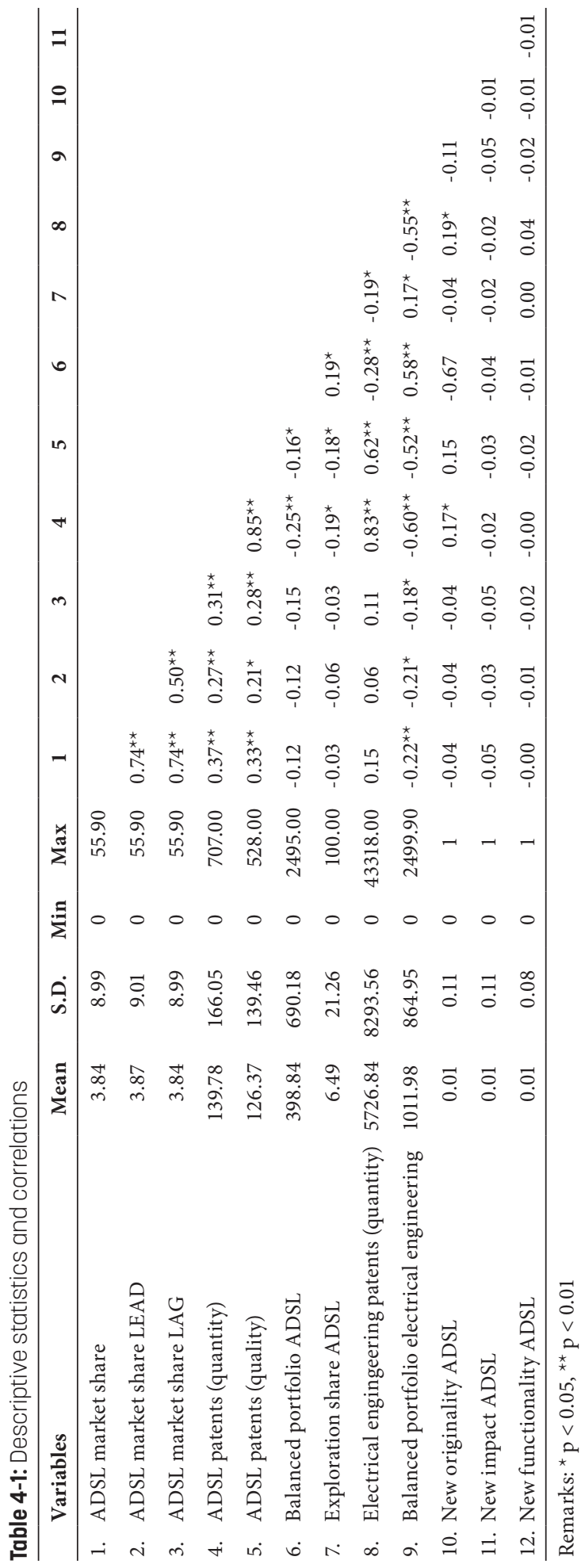


Table 4-2: Ranking market share ADSL ports (1998-2003, in \%)

\begin{tabular}{|c|c|c|c|c|c|c|}
\hline & 1998 & 1999 & 2000 & 2001 & 2002 & 2003 \\
\hline 1 & Alcatel 41\% & Alcatel 56\% & Alcatel $47 \%$ & Alcatel 37\% & Alcatel 33\% & Alcatel 35\% \\
\hline 2 & Cisco 30\% & Orckit 14\% & Cisco $12 \%$ & Siemens $11 \%$ & NEC 9\% & NEC 7\% \\
\hline 3 & Paradyne $12 \%$ & Cisco 10\% & Lucent $11 \%$ & Lucent 8\% & Sumitomo $8 \%$ & Utstarcom $7 \%$ \\
\hline 4 & Nortel 8\% & Nortel 8\% & Samsung 6\% & Sumitomo $7 \%$ & Utstarcom 6\% & Lucent $6 \%$ \\
\hline 5 & Nokia 4\% & Paradyne $4 \%$ & Nortel 5\% & Cisco 6\% & Samsung 6\% & Sumitomo 5\% \\
\hline 6 & ECI 1\% & Nokia $2 \%$ & Nokia $4 \%$ & ECI 6\% & ECI 5\% & Siemens 5\% \\
\hline 7 & Samsung $1 \%$ & ECI $1 \%$ & Orckit $4 \%$ & Samsung 5\% & Lucent 5\% & ECI $3 \%$ \\
\hline 8 & $\operatorname{ADC} 0,4 \%$ & Samsung $1 \%$ & Ericsson $2 \%$ & NEC 5\% & Siemens 5\% & Nokia $2 \%$ \\
\hline 9 & PairGain $0,4 \%$ & Lucent $1 \%$ & ECI $2 \%$ & Orckit 3\% & Ericsson $2 \%$ & Samsung $2 \%$ \\
\hline 10 & & Westell 1\% & Paradyne $2 \%$ & Nokia 2\% & Nokia 2\% & Cisco 1\% \\
\hline 11 & & ADC $0.3 \%$ & Westell 1\% & Ericsson 2\% & Cisco $2 \%$ & Ericsson 1\% \\
\hline 12 & & PairGain $0.3 \%$ & NEC $0.2 \%$ & Paradyne $1 \%$ & Paradyne $1 \%$ & Paradyne $0.4 \%$ \\
\hline 13 & & & Siemens $0.2 \%$ & Utstarcom $1 \%$ & Orckit $1 \%$ & \\
\hline 14 & & & Sumitomo $0.2 \%$ & Westell 0.4\% & & \\
\hline 15 & & & ADC $0.1 \%$ & ADC $0.1 \%$ & & \\
\hline $\begin{array}{l}\text { Total } \\
\text { units } \\
\text { (000's) }\end{array}$ & $2.128,00$ & $2.765,80$ & $12.059,86$ & $20.380,90$ & $19.607,50$ & $33.798,80$ \\
\hline
\end{tabular}

In order to examine our research questions whether market leadership in an emerging hightech market coincides with technological leadership and whether a balanced patent portfolio matters, we first present a firm's ADSL market share and cumulative number of patents in a graph. These visual representations are followed by analyses of covariance (ANCOVA) with a one-way between subjects design in which firm is included as fixed factor. The inter-correlations among the covariates and the dependent variable show that the covariates meet the basic requirements of ANCOVA (see Table 4-1). ${ }^{24}$ We note that the assumptions of normally distributed residuals and homogeneity of variance are not met. ${ }^{25}$ Nevertheless, the analysis technique remains robust for the purpose of examining our research data and questions. Mathematical and empirical research shows that ANCOVA continues to be robust if the variances are heterogeneous, when sample sizes are equal (Reed \& Stark, 1995). Non-normal datasets appear to be rather the rule than the exception (Reed \& Stark, 1995, p. 87).

While in the strictest of senses, the assumptions for ANCOVA are not met, they do not apply to the analysis at hand. In the analysis, the main categorical independent variable 'firm' is observed and not manipulated. As such, the independence assumption between the covariate and the independent variable is irrelevant (Keppel \& Wickens, 2004). This implies that the results require interpretation as results from an observational study, and not as if they were from an experiment (where ANCOVA is frequently applied in an experimental setup, where the categorical independent is manipulated).

24 The covariates are not highly correlated $(r>0.8)$ when more than 1 covariate is used within the ANCOVA model and the covariates correlate with the dependent variable.

25 Levene's test is significant and the residuals are skewed, although not very skewed. Data-transformation would not be usefull 
For reasons of readability, we opted to visualize all firms that obtained a top three position in the ADSL market (i.e. top three in period 1998-2003). In addition, Ericsson is added to the graphs due to the link with chapter four. ${ }^{26}$ As a result, ten firms are included in these graphs (Alcatel, Cisco, Ericsson, Paradyne, Orckit, Lucent, Siemens, NEC, Sumitomo Electric and Utstarcom). For further clarity, we chose to show just three points in time $(1998,2000$ and 2002) in order to give a comprehensive, yet clear view on the data.

Figure 4-1 shows the ADSL patent portfolio in relation to ADSL market share. Siemens has consistently the largest number of ADSL patents. The firm entered the ADSL market in 2000 with a market share of $0,2 \%$ The highest market share ranking was achieved in 2001 with $11 \%$, as can be seen in table 4-1. From 2002 onwards, Siemens experienced a decline to 5\% market share. In contrast, Alcatel has fewer ADSL patents compared to Siemens but the firm enters the market as a market leader and keeps its leadership position. Interestingly, NEC and Lucent are building their ADSL patent portfolio at a seemingly similar speed as Alcatel, yet never come close to obtaining a similar market share. Having a relatively low number of ADSL patents, Cisco obtains a market share of $30 \%$ in the first year. Although Cisco continued its ADSL innovation activities and increases its number of ADSL patents in this period, the firm's market share continues to drop to $2 \%$ in 2002 . Whereas Utstarcom - a late entrant - never obtains many patents in the ADSL technology, yet is able to steadily increase its market share. These results suggest that market leadership in an emerging market does not coincide with technological leadership in the core technology. A similar pattern is obtained for citation-weighted patents, taking into account the quality of the ADSL patent stock, as can be seen in figure 4-2.

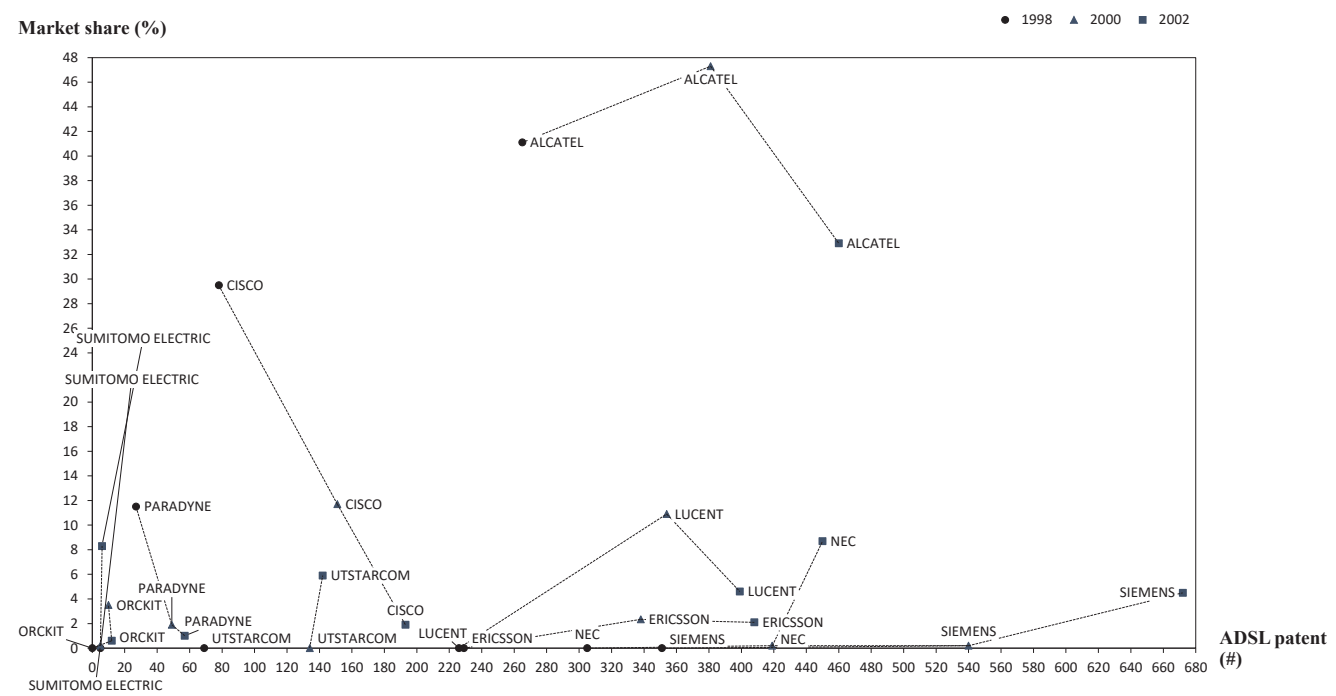

Figure 4-1: Total number of ADSL patents in relation to ADSL market share (1998-2002]

26 Chapter four presents a comparative case study of the ADSL innovation journey from Alcatel and Ericsson. 
Figure 4-2 illustrates the quality of the ADSL patents in relation to ADSL market share. Lucent has the highest quality in its ADSL patent portfolio, followed by NEC. Neither Lucent nor NEC become market leader.

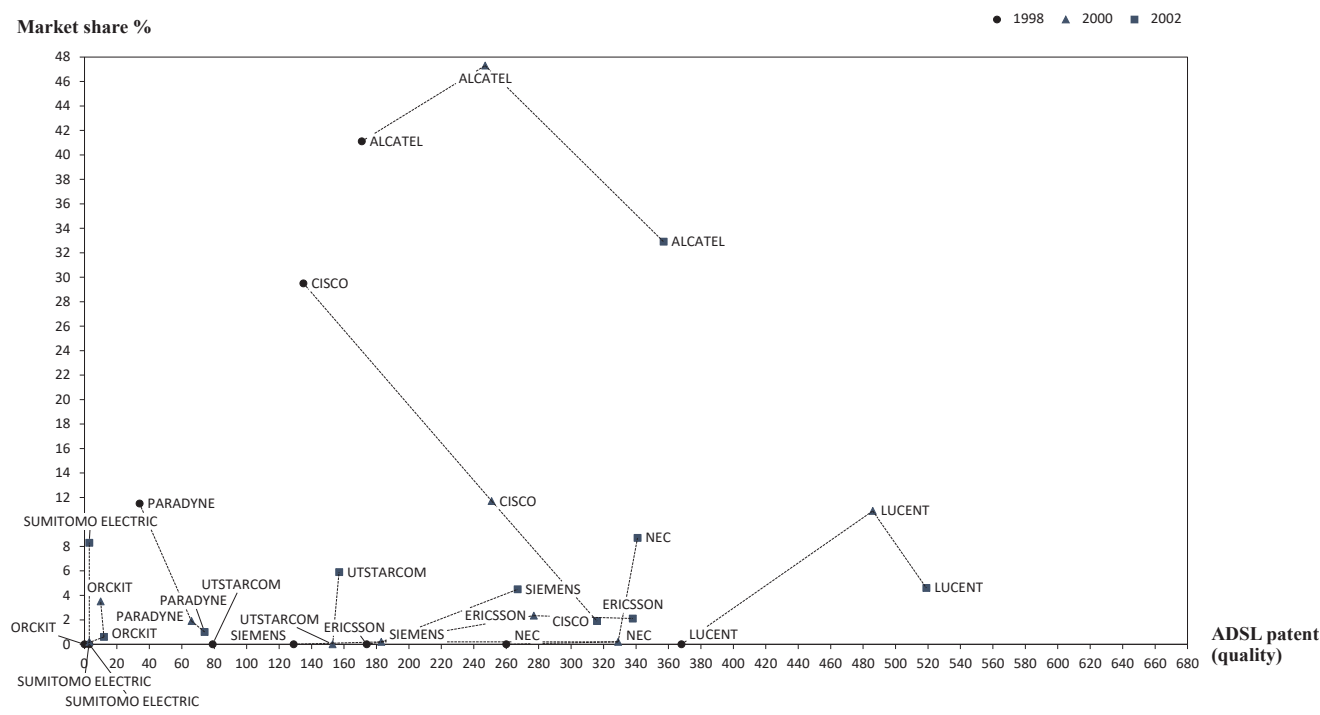

Figure 4-2: Total number of citation-weighted ADSL patents in relation to ADSL market share (1998-2002]

The subsequent ANCOVA tests provides additional insights, which are shown in table 4-3. Three different models are tested. First, a simultaneous approach in which the technological activities (cumulative) of the firm are analyzed in relation to the market share they achieved in the same year. Second, an approach that moves market share one year forward in relation to the technological activities of the firm. Third, a model that delays market share with one year. ${ }^{27}$ (For example market share in year 1998 becomes market share in 1999.

The results of the ANCOVA show a significant difference in market share between the firms. Whilst adjusting for ADSL patents, patent quantity and quality significantly predict market share in all three models. Considering a firm's technological activity in relation to the market share in the same year, the covariate, number of ADSL patents, significantly predicts market share, $\mathrm{F}(1,123)=24.57, p=.000$. The adjusted $\mathrm{R}^{2}$ equals to .53 or $53 \%$ of the variance in market share is explained by the applied model. ${ }^{28,29}$ Quality of ADSL patents also significantly predicts market

27 '1 year lead' implies for example, market share 1999 becomes market share 1998. In contrast, '1 year lag' refers to for example market share 1999 that becomes market share 2000.

28 If only firm is included in the model, the adjusted R2 equals to 0.45 or $45 \%$.

29 If we leave out fixed effects, the number of ADSL patents significantly predicts market share $\mathrm{F}(1,139)=$ $22.38, p=.000$. However, the adjusted R2 equals to 0.13 or $13 \%$. 
share, $\mathrm{F}(1,123)=17.76, p=.000$. The adjusted $\mathrm{R}^{2}$ of .51 or $51 \%$ illustrates a good model fit. ${ }^{30}$ The covariates, ADSL patent quantity, $\mathrm{F}(1,106)=13.39, p=.000$ and ADSL patent quality $\mathrm{F}(1,106)$ $=7.89, p=.006$ each have a significant effect on market share in the year before. Both quantity, $\mathrm{F}(1,111)=25.25, p=.000$, and quality of the ADSL patents, $\mathrm{F}(1,111)=21.84, p=.000$, also have a significant effect on market share when market share is taken into account one year after a firm's particular technological position..$^{31,32}$

Table 4-3: Results of one-way between-subjects analysis of covariance of a firm's activities in the core technology and market share

\begin{tabular}{|c|c|c|c|c|c|c|c|c|c|}
\hline \multirow{3}{*}{ Variables } & \multicolumn{3}{|c|}{ Market share } & \multicolumn{3}{|c|}{ Market share lead (1y) } & \multicolumn{3}{|c|}{ Market share lag (1y) } \\
\hline & Model 1 & Model 2 & & Model 1 & Model 2 & & Model 1 & Model 2 & \\
\hline & F & $\mathbf{F}$ & df & F & F & df & F & $\mathbf{F}$ & df \\
\hline ADSL patents (quantity) & $24.576^{\star *}$ & & 1 & $13.388^{* *}$ & & 1 & $25.249^{* *}$ & & 1 \\
\hline ADSL patents (quality) & & $17.760^{* *}$ & 1 & & $7.891^{* *}$ & 1 & & $21.839^{* *}$ & 1 \\
\hline Firm & $8.496^{* *}$ & $8.345^{\star *}$ & 16 & $9.185^{\star *}$ & $9.161^{\star *}$ & 16 & $7.335^{\star *}$ & $7.287^{\star *}$ & 16 \\
\hline Error & & & 123 & & & 106 & & & 111 \\
\hline Total & & & 141 & & & 124 & & & 129 \\
\hline R Squared & 0.591 & 0.571 & & 0.632 & 0.615 & & 0.574 & 0.563 & \\
\hline Adjusted R Squared & 0.534 & 0.512 & & 0.573 & 0.553 & & 0.509 & 0.497 & \\
\hline
\end{tabular}

Remarks: ${ }^{\star} \mathrm{p}<0.05,{ }^{\star *} \mathrm{p}<0.01$

While the above analyses examine the relationship between a firm's core, ADSL, technology activities, the following analyses focus on the possible importance of complementary technological activities in the field of electrical engineering. Figure 4-3 illustrates the patent portfolio in the area of electrical engineering in relation to ADSL market share. This technological domain contains technologies that are complementary to ADSL. Siemens, NEC and Ercisson have the highest number of patents in electrical engineering. None of these firms achieve a leadership position in the ADSL market. Although both Siemens and NEC belong to the market share top three at a certain moment in time, the difference in market share compared to Alcatel remains very large. Despite the large number of patents in electrical engineering, Ericsson never got more than $2 \%$ of the ADSL market. Utstarcom is again an interesting case, as this late entrant has very few patents in the core and complementary technologies. The firm realized a larger market share compared to Siemens at the end of the emerging market phase. The other companies that reach the top three position of market share, Orckit, Paradyne, Sumitomo Electric and Cisco, also appear to have relatively few patents in the field of electrical engineering.

30 If we leave out fixed effects, the quality of ADSL patents significantly predicts market share $\mathrm{F}(1,139)=16.38$, $p=.000$. However, the adjusted R2 equals to 0.10 or $10 \%$.

31 Similar results are obtained if we lead and lag market share with 2 years instead of 1 year.

32 Similar results are obtained if we swop the dependent and independent variable so that patents become the dependent variable and market share the independent variable. 


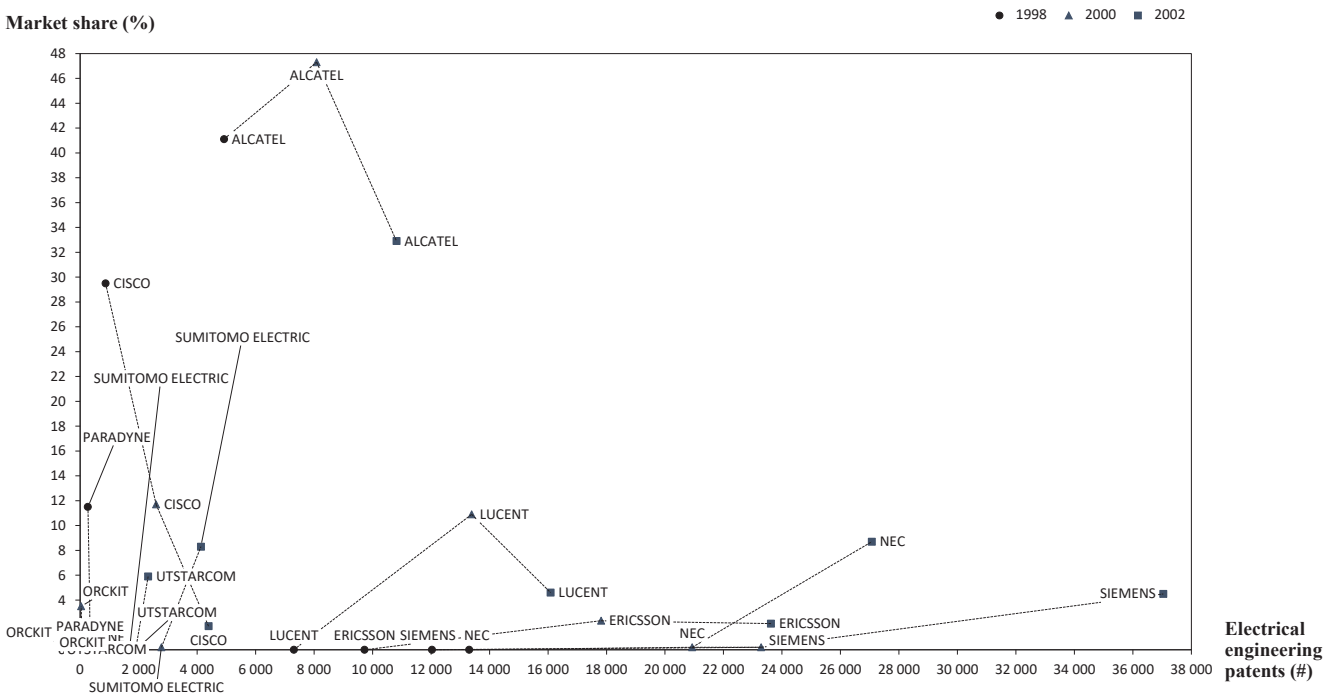

Figure 4-3: Total number of electrical engineering patents in relation to ADSL market share [1998-2002]

The analysis of covariance show a similar pattern for complementary technologies compared to a firm's technological activities in the core, ADSL, technology. The results of the ANCOVA show a significant difference in market share between the firms. Whilst adjusting for electrical engineering patents, the number of electrical engineering patents significantly predicts market share in the three models.

Looking at a firm's technological activity in relation to the market share in the same year, the covariate, number of patents in electrical engineering, significantly predicts market share, $\mathrm{F}(1,123)=11.02, p=.001$. The adjusted $\mathrm{R}^{2}$ equals to .49 or $49 \%$ of the variance in market share is explained by the applied model.

A significant influence is found on the market share one year before the firm's technological position in the field of electrical engineering, $\mathrm{F}(1,106)=8.28, p=.005$. There is also a significant effect of the number of electrical engineering patents on the market share one year after the firm's patent activities, $\mathrm{F}(1,98)=8.35, p=.002 \cdot{ }^{33,34}$

33 Similar results are obtained if we lead and lag market share with 2 years instead of 1 year.

34 Similar results are obtained if we swop the dependent and independent variable so that patents become the dependent variable and market share the independent variable. 
Table 4-4: Results of one-way between-subjects analysis of covariance of a firm's activities in complementary technologies and market share

\begin{tabular}{|c|c|c|c|c|c|c|}
\hline \multirow{2}{*}{ Variables } & \multicolumn{2}{|c|}{ Market share } & \multicolumn{2}{|c|}{ Market share lead (1y) } & \multicolumn{2}{|c|}{ Market share lag (1y) } \\
\hline & $\mathbf{F}$ & df & $\mathbf{F}$ & df & $\mathbf{F}$ & df \\
\hline Electrical engineering patents & $11.018^{\star *}$ & 1 & $8.284^{* *}$ & 1 & $8.353^{* *}$ & 1 \\
\hline Firm & $9.015^{\star *}$ & 16 & $10.337^{\star *}$ & 16 & $5.856^{* *}$ & 16 \\
\hline Error & & 123 & & 106 & & 98 \\
\hline Total & & 141 & & 124 & & 116 \\
\hline R Squared & 0.549 & & 0.616 & & 0.494 & \\
\hline Adjusted R Squared & 0.487 & & 0.554 & & 0.406 & \\
\hline
\end{tabular}

Remarks: ${ }^{*} \mathrm{p}<0.05,{ }^{* *} \mathrm{p}<0.01$

\subsection{Market leadership and balancing technological exploration and exploitation}

Next, this paper explores whether firms that display a strong balance in exploratory and exploitative technological activity are more likely to become market leaders in an emerging market. Figure 4-4 shows how a balanced patent portfolio in complementary technological activities is related to a firm's leadership position in the ADSL market. Utstarcom and Paradyne have the highest degree of balance in their electrical engineering patents. Both firms are once-only ranked third in ADSL market share statistics. Orckit suddenly jumps from no balance to a high balance degree, caused by a sudden increase in exploration patents in electrical engineering. However, Orckit solely reaches a one-time top three market share position in 1999, as table 4-2 illustrates. The market leader, Alcatel, seems to have a relatively low but stable degree of balance in its electrical engineering patents. A more or less similar pattern occurs in Lucent, NEC and Siemens. Ericsson, with a highest market share of $2 \%$, had a stronger balance in exploratory and exploitative electrical engineering technology development.

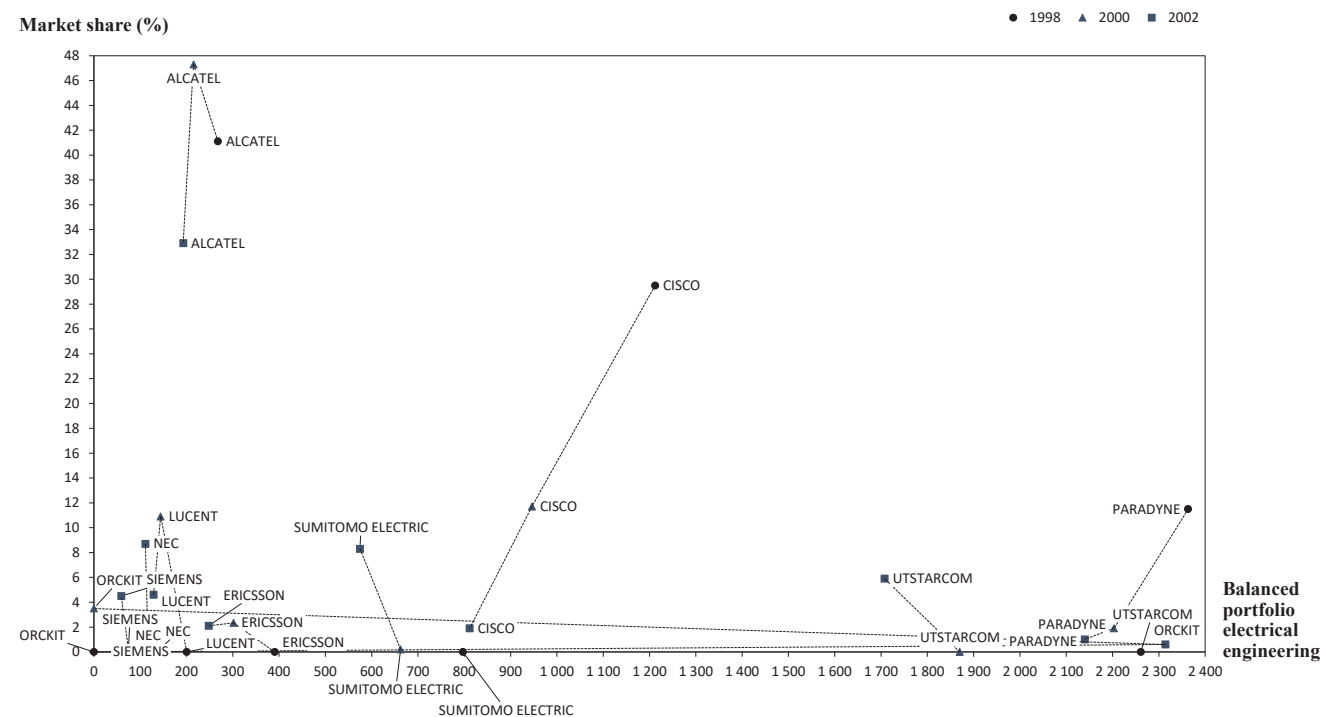

Figure 4-4: Degree of balanced portfolio in electrical engineering patents in relation to ADSL market share (1998-2002] 
The results of the ANCOVA show that there is a significant difference in market share between the firms and the number of electrical engineering patents significantly predicts market share in the three models. However, adjusting for the degree of balanced portfolio or the extent to which exploration and exploitation in technologies complementary to ADSL technologies simultaneously occur, shows no significant effect on market share. This observation is regardless if market share is taken into account in the same year $(\mathrm{F}(1,121)=0.004, p=.951)$, one year before technology development $(\mathrm{F}(1,104)=0.024, p=.878)$ or one year after technology development $(\mathrm{F}(1,109)=$ $0.053, p=.818)$.

Table 4-5: Results of one-way between-subjects analysis of covariance of a firm's exploratory and exploitative activities in complementary technologies and market share

\begin{tabular}{lcccccc}
\hline \multirow{2}{*}{$\begin{array}{l}\text { Variables } \\
\text { Market share }\end{array}$} & \multicolumn{2}{c}{ Market share lead (1y) } & \multicolumn{2}{c}{ Market share lag (1y) } \\
& F & df & F & df & F & df \\
\hline Electrical engineering patents & $9.243^{* *}$ & 1 & $6.784^{*}$ & 1 & $8.721^{* *}$ & 1 \\
Balanced portfolio electrical engineering & 0.004 & 1 & 0.024 & 1 & 0.053 & 1 \\
Balanced portfolio square term & 0.026 & 1 & 0.005 & 1 & 0.000 & 1 \\
Firm & $8.436^{* *}$ & 16 & $9.626^{* *}$ & 16 & $6.768^{* *}$ & 16 \\
Error & & 121 & & 104 & 109 \\
Total & & 141 & & 124 & & 129 \\
R Squared & 0.551 & & 0.618 & & 0.525 & 0.442 \\
Adjusted R Squared & 0.481 & & 0.548 & & &
\end{tabular}

Remarks: ${ }^{\star} \mathrm{p}<0.05,{ }^{* *} \mathrm{p}<0.01$

\subsection{Market leadership and novelty in core technology development}

In addition to examining the balance between exploration and exploitation in firm's patent portfolio, table 4-6 shows the results of exploring to what extent novelty in the core technology development enables market leadership in an emerging high-tech market. There remains to be a significant difference in market share between the firms and patent quality significantly predicts market share in the simultaneous $(\mathrm{F}(1,102)=11.01, p=.001)$ and lagged model $(\mathrm{F}(1,107)=22.03$, $p=.000)$. None of the novelty indicators seem to impact market share. New originality in ADSL, new impact in ADSL, new functionality in ADSL, and a firm's share of exploration patents, show no significant results. 
Table 4-6: Results of one-way between-subjects analysis of covariance of a firm's novelty in the core technology and market share

\begin{tabular}{|c|c|c|c|c|c|c|}
\hline \multirow{2}{*}{ Variables } & \multicolumn{2}{|c|}{ Market share } & \multicolumn{2}{|c|}{ Market share lead (1y) } & \multicolumn{2}{|c|}{ Market share lag (1y) } \\
\hline & F & df & $\mathbf{F}$ & df & $\mathbf{F}$ & df \\
\hline ADSL patents (quality) & $11.012^{* *}$ & 1 & 2.170 & 1 & $22.032^{\star *}$ & 1 \\
\hline New originality ADSL & 0.314 & 1 & 0.186 & 1 & 0.215 & 1 \\
\hline New impact ADSL & 0.000 & 1 & 0.000 & 1 & 0.120 & 1 \\
\hline New functionality ADSL & 0.042 & 1 & 0.001 & 1 & 0.002 & \\
\hline Exploration share ADSL & 0.970 & 1 & 0.004 & 1 & 0.919 & \\
\hline Firm & $9.068^{* *}$ & 16 & $10.937^{\star *}$ & 16 & $7.040^{* *}$ & 16 \\
\hline Error & & 102 & & 85 & & 107 \\
\hline Total & & 124 & & 107 & & 129 \\
\hline R Squared & 0.629 & & 0.699 & & 0.569 & \\
\hline Adjusted R Squared & 0.553 & & 0.624 & & 0.484 & \\
\hline
\end{tabular}

Remarks: ${ }^{*} \mathrm{p}<0.05,{ }^{* *} \mathrm{p}<0.01$

\section{Conclusion and discussion}

\subsection{Summary and discussion of main findings}

Despite the assumed importance of technological innovation efforts for capturing market share in high-tech industries, the relationship between market leadership and technological leadership has not been explored extensively. This study provides empirical evidence for 17 firms that cover the global emerging market of ADSL technology during its first six years (1998-2003).

Relying on patent data from 1990 to 2003 and market data from 1998 to 2003, this research explores whether market leadership requires technological leadership in an emerging hightech market. Technological leadership is studied at two levels: core technology (ADSL) and complementary technologies (electrical engineering). We also examine to what extent the balanced nature of a firm's technological portfolio, i.e. the combination of exploration and exploitation patents in the firm's portfolio, matters to become market leader in an emerging high-tech market.

The results suggest that market leadership in the early phase of this emerging high-tech market does not require technological leadership, although a firm's number of patents and patent quality in ADSL technology seem to have an effect on their ADSL market share. A similar observation holds for the number of patents in the complementary technologies, belonging to the field of electrical engineering. The data shows that a firm does need to have patents in the core and complementary technologies to become a market leader, but being a technology leader does not automatically imply market leadership.

While one might expect that market share follows technological development, our data suggests there is an influence from technology to market and from market to technology. Besides a parallel development of technology and market share, it seems that technological development 
also follows market share and vice versa. This relation from market to technology can be explained by the market-pull mechanism as market-pull dynamics pull (push) 'the winners' to invest in technology. Prior studies from for example Schmoch (2007) and Granstrand (1998) also illustrate the technology follows market phenomenon.

We observe a relation between technology and market share, but it is clear that other elements besides technology also play a role in achieving market success. This finding is supported by the descriptive analyses and the fact that only a limited part of the variance is explained if we omit the fixed effects in the models.

A balanced technological portfolio in terms of simultaneous exploration and exploitation does not seem to matter much to become market leader in the emerging high-tech market of ADSL. This conclusion holds for technological development in the complementary technologies, electrical engineering. A close examination of the data shows that firms with a rather consistent degree of balance in exploration and exploitation in their adjacent technologies, seem to be more likely to become and remain market leader in the new high-tech market. Although engaging in both technology exploration and exploitation is far from easy, multiple studies prove the benefits of being able to explore and exploit (e.g. O’Reilly \& Tushman, 2013; Swift, 2016). R\&D-based exploration and exploitation is necessary for firms. A consistent level of exploration and exploitation allows for ongoing cross-fertilization effects, capability building and potential to react in a dynamic hightech environment. This also corresponds to the extensive literature on innovation management, explaining the importance of continuous investments in technological activity.

Finally, we examined to what extent novelty in a firm's technological activities matter to become market leader in the new ADSL market. The results show that novelty has no influence on market leadership in the ADSL market. Neither novelty in terms of a firm's share of exploration patents in relation to its total patents in the core technology, nor novelty in terms of being the firm in the industry with real novel patents seem to be related to market leadership. This conclusion follows prior research, addressing that being an inventor or the first to develop and patent a technology is not necessarily the product or market pioneer of that technology (Golder \& Tellis, 1993). Academic scientists and firms can for example target a different goal, such as creating new knowledge to build reputation in the scientific community versus creating new technological solutions to gain market success (Schmoch, 2007). While technology development of an exploratory nature on a firm-level is important, as explained above, novelty on an industry-level seems no condition to be successful in the market and to become market leader.

In sum, our findings indicate that technological leadership does not seem to be a decisive factor for market leadership. Alcatel dominates the ADSL market for at least six years since the market emerged, but the firm is no technology leader. Moreover, the results show that having patents does not automatically imply a successful end product to sell on the market. For example, despite their leading position in terms of patent quantity and quality, it seems that Siemens and NEC were not ready to sell their product at the moment the ADSL market took off, as they do not have any market share in the early years. Although technology is a necessary condition, what really counts to become market leader is more than technology. 


\subsection{Research implications}

This study contributes to our knowledge about the role of technology in market leadership and the relevance of combining exploration and exploitation efforts in an emerging market. We show that patents do not explain market leadership in an emerging high-tech market although patents are an important indicator of technological activity in high-tech industries. The results also indicate that it is not about displaying a strong level of a balanced portfolio of exploration and exploitation in technological activity in order to capture market share and a leading market position. Our dataset asked for a careful look at each of the players in the market. This firm level analysis reveals that the relationship between market leadership and technological leadership is complex and nuanced.

While patents are often used as a proxy for the learning that takes place in a firm (see for instance Hu et al. (2014)), this research suggests that a broader perspective is needed as patents do not explain market success. It is also important to understand the value and timing of essential exploration and exploitation activities in the context of an emerging market. March (1991) and other scholars such as Tushman and O’Reilly (1996) do not consider exploration and exploitation as a technological activity only. Let alone that both have been considered at the level of a single technology field.

\subsection{Managerial implications}

This study shows that obtaining market leadership is not about having the most or a large number of patents in the core or complementary technologies. Patents are expensive to obtain and maintain. Being able to capitalize on this investment is thus important. A firm like Siemens invested heavily in building its patent portfolio, yet was not able to capitalize on this investment nearly as effectively as Alcatel was on their much more modest patent portfolio. In the context of technological activity, this means that firms should continue both explorative and exploitative efforts when a market is still in its early stage. Also, if a firm targets the entry and survival on an emerging market, our results indicate that this firm will benefit from a constant focus on the core technology in the context of its broader technological activities while the market is still shaping.

The benefits of being active in different technology fields are empirically proven, but attention should be paid not to lose focus. A firm needs to have a reasonably concentrated technology focus. For example, whereas Lucent and NEC have a rather similar amount of ADSL patents as Alcatel, it seems that both firms may have been distracted by simultaneous developments in other adjacent fields, as their patent counts in adjacent technologies are much higher than that of Alcatel. Neither Lucent nor NEC reach a market leader position in the emerging market.

Maintaining a consistent balance between exploration and exploitation patents seems to pay off in the presence of an emerging high-tech market. This probably means that over time, a firm's exploration efforts will even have to increase when a market starts to take off, because it will become more and more difficult to add something novel as the market becomes more mature and an increasing number of exploitative patents are being filed. To clarify, we are discussing here the early phase of a technology's life cycle. The data only cover the first six years of this market. Clearly when a market matures and cost efficiencies become more important, the focus on exploitation becomes more important. 


\subsection{Limitations and directions for future research}

Our research is subject to limitations that at the same time give perspective for future research. First, the findings rely on quantitative market share and patent data. Although this is an important data source, other factors may play a role in obtaining market leadership. In fact, our findings ask for an in-depth comparative case study in the telecommunications equipment industry in order to fully understand how Alcatel reached a sustainable market leadership position, while similar competing firms did not succeed in gaining any significant or sustainable market share in the new ADSL market. What other factors than the patent portfolios of these firms were at play? These questions are being answered in chapter four.

Second, the results are limited to descriptive analyses of patents and market share data and univariate analyses of covariance. The data now reveal intriguing insights about the technology strategies of the 17 studied firms and its impact on market share in the emerging ADSL market. A multiple case study approach of these 17 firms can be very interesting. It might be worthwhile to expand the dataset with consolidated financial data and additional data for the years after the emerging market phase. This would involve a new research question.

Third, we acknowledge that technologies differ by sector and by complexity. This research focusses on the ADSL technology. This technology experienced its own technology cycle. It might be interesting to conduct similar research in other technology areas such as biotech. 


\section{References}

Ahuja, G., \& Lampert, C. M. 2001. Entrepreneurship in the large corporation: A longitudinal study of how established firms create breakthrough inventions. Strategic Management Journal, 22(6-7): 521-543.

Asimakopoulos, G., \& Whalley, J. 2017. Market leadership, technological progress and relative performance in the mobile telecommunications industry. Technological Forecasting and Social Change, 123: 57-67.

Bakker, J., Verhoeven, D., Zhang, L., \& Van Looy, B. 2016. Patent citation indicators: One size fits all? Scientometrics, 106(1): 187-211.

Barney, J. B. 1996. The resource-based theory of the firm. Organization Science, 7(5): 469-469.

Belderbos, R., Faems, D., Leten, B., \& Van Looy, B. 2010a. Technological Activities and Their Impact on the Financial Performance of the Firm: Exploitation and Exploration within and between Firms. Journal of Product Innovation Management, 27(6): 869-882.

Belderbos, R., Sleuwaegen, L., \& Veugelers, R. 2010b. Market Integration and Technological Leadership in Europe, Economic Papers: 1-152. Brussels: European Commission.

Belderbos, R., \& Somers, D. 2015. Do Technology Leaders Deter Inward R\&D Investments? Evidence from Regional R\&D Location Decisions in Europe. Regional Studies, 49(11): 1805-1821.

Bernard, J., Cantner, U., \& Westermann, G. 1996. Technological leadership and variety: A Data Envelopment Analysis for the French machinery industry. Annals of Operations Research, 68: 361-377.

Brace, N., Kemp, R., \& Snelgar, R. 2006. SPSS for psychologists (3 ed.). New York, N.Y.: Palgrave Macmillan.

Burhan, M., Singh, A. K., \& Jain, S. K. 2017. Patents as proxy for measuring innovations: A case of changing patent filing behavior in Indian public funded research organizations. Technological Forecasting and Social Change, 123: 181-190.

Cantwell, J., \& Janne, O. 1999. Technological globalisation and innovative centres: the role of corporate technological leadership and locational hierarchy. Research Policy, 28(2-3): 119-144.

Chen, W. Y. 1999. The development and standardization of asymmetrical digital subscriber line. Ieee Communications Magazine, 37(5): 68-72.

Chesbrough, H. 1999. Arrested development: the experience of European hard disk drive firms in comparison with US and Japanese firms. Journal of Evolutionary Economics, 9(3): 287-329.

Chow, C. K. W., \& Fung, M. K. Y. 1997. Measuring the technological leadership of international joint ventures in a transforming economy. Journal of Business Research, 39(2): 147-157.

Cohen, W. M. 2010. Fifty years of empirical studies of innovative activity and performance, Handbook of the Economics of Innovation, First ed., Vol. 1: 129-213. Amsterdam: North-Holland.

Coombs, J. E., Deeds, D. L., \& Ireland, R. D. 2009. Placing the choice between exploration and exploitation in context: A study of geography and new product development. Strategic Entrepreneurship Journal, 3(3): 261-279.

Dekeyser, S. 2009. Technology life cycles: review of the literature and an explorative empirical study based ISDN, ADSL and VOIP patent applications. Catholic Uninversity Leuven, Leuven.

DeLacey, B., Herman, K., Kiron, D., \& Lerner, J. 2006. Strategic Behavior in Standard-Setting Organizations: Harvard Business School.

Dowling, M. J., \& McGee, J. E. 1994. Business and technology strategies and new venture performance - A study of the telecommunications equipment industry. Management Science, 40(12): 1663-1677.

Drezner, D. 2001. State structure, technological leadership and the maintenance of hegemony. Review of International Studies, 27(1): 3-25.

Edeling, A., \& Himme, A. 2018. When Does Market Share Matter? New Empirical Generalizations from a MetaAnalysis of the Market Share-Performance Relationship. Journal of Marketing, 82(3): 1-24.

EPO. 2017. Patent families at the EPO. Munich: European Patent Office.

Fontana, R., \& Vezzulli, A. 2016. Technological leadership and persistence in product innovation in the Local Area Network industry 1990-1999. Research Policy, 45(8): 116-131.

Galasso, A., \& Schankerman, M. 2018. Patent rights, innovation, and firm exit. Rand Journal of Economics, 49(1): 64-86.

Garcia-Vega, M. 2006. Does technological diversification promote innovation? An empirical analysis for European firms. Research Policy, 35(2): 230-246. 
Geerts, A., Leten, B., Belderbos, R., \& Van Looy, B. 2018. Does Spatial Ambidexterity Pay Off? On the Benefits of Geographic Proximity Between Technology Exploitation and Exploration. Journal of Product Innovation Management, 35(2): 151-163.

Golder, P. N., \& Tellis, G. J. 1993. Pioneer advantage - marketing logic or marketing legend. Journal of Marketing Research, 30(2): 158-170.

Goralski, W. J. 2002. ADSL \& DSL Technologies. Berkeley: McGraw-Hill.

Granstrand, O. 1998. Towards a theory of the technology-based firm. Research Policy, 27(5): 465-489.

Granstrand, O., \& Holgersson, M. 2013. Managing the Intellectual Property Disassembly Problem. California Management Review, 55(4): 184-210.

Granstrand, O., Patel, P., \& Pavitt, K. 1997. Multi-technology corporations: Why they have "distributed" rather than "distinctive core" competencies. California Management Review, 39(4): 8-\&.

Griliches, Z. 1990. Patent statistics as economic indicators. Journal of Economic Literature, 28(4): 1661-1707.

Guite, J. M. 1987. Telecommunications Equipment: The United States Market. NY: Salomon Brothers.

Hall, B. H., Jaffe, A., \& Trajtenberg, M. 2005. Market value and patent citations. Rand Journal of Economics, 36(1): 16-38.

He, Z. L., \& Wong, P. K. 2004. Exploration vs. exploitation: An empirical test of the ambidexterity hypothesis. Organization Science, 15(4): 481-494.

Heyden, M. L. M., Oehmichen, J., Nichting, S., \& Volberda, H. W. 2015. Board background heterogeneity and exploration-exploitation: The role of the institutionally adopted board model. Global Strategy Journal, 5(2): 154-176.

Hu, M. C., Kang, J. S., \& Wu, C. Y. 2017. Determinants of profiting from innovation activities: Comparisons between technological leaders and latecomers. Technological Forecasting and Social Change, 116: 223-236.

Hu, M. C., Wu, C. Y., Lee, J. H., \& Lu, Y. C. 2014. The influence of knowledge source and ambidexterity in the thin film transistor and liquid crystal display industry: evidence from Japan, Korea, and Taiwan. Scientometrics, 99(2): 233-260.

Jaffe, A. B., \& de Rassenfosse, G. 2017. Patent citation data in social science research: Overview and best practices. Journal of the Association for Information Science and Technology, 68(6): 1360-1374.

Jaffe, A. B., \& Lerner, J. 2006. Innovation and its discontents.

Kaplan, S. N. 1994. Top executive rewards and firm performance : A comparison of Japan and the United States. Journal of Political Economy, 102(3): 510-546.

Kato, M., \& Honjo, Y. 2009. The persistence of market leadership: evidence from Japan. Industrial and Corporate Change, 18(6): 1107-1133.

Keppel, G., \& Wickens, T. 2004. Design and analysis: $\boldsymbol{A}$ researcher's handbook (4 ed.). Englewood Cliffs, NJ: Prentice-Hall, Inc.

Kim, J., Lee, C. Y., \& Cho, Y. 2016. Technological diversification, core-technology competence, and firm growth. Research Policy, 45(1): 113-124.

Lee, C. Y., \& Huang, Y. C. 2012. Knowledge stock, ambidextrous learning, and firm performance Evidence from technologically intensive industries. Management Decision, 50(6): 1096-1116.

Leiponen, A., \& Helfat, C. E. 2010. Innovation objectives, knowledge sources and the benefits of breadth. Strategic Management Journal, 31(2): 224-236.

Leten, B., Belderbos, R., \& Van Looy, B. 2007. Technological diversification, coherence, and performance of firms. Journal of Product Innovation Management, 24(6): 567-579.

Liikanen, E. 2001. The European Union Telecommunications Policy, Telecommunications Seminar. Sarajevo: European Union.

March, J. G. 1991. Exploration and exploitation in organizational learning. Organization Science, 2(1): 71-87.

Mathias, B. D., McKenny, A. F., \& Crook, T. R. 2018. Managing the tensions between exploration and exploitation: The role of time. Strategic Entrepreneurship Journal, 12(3): 316-334.

McKenney, J. L., Mason, R. O., \& Copeland, D. G. 1997. Bank of America: The crest and trough of technological leadership. Mis Quarterly, 21(3): 321-353.

Miller, D. J. 2006. Technological diversity, related diversification, and firm performance. Strategic Management Journal, 27(7): 601-619.

Na, W. B., Son, Y. S., \& Marshall, R. 2007. Why buy second-best? The behavioral dynamics of market leadership. Journal of Product and Brand Management, 16(1): 16-+. 
O’Reilly, C. A., \& Tushman, M. L. 2013. Organizational ambidexterity: Past, present, and future. Academy of Management Perspectives, 27(4): 324-338.

OECD. 2009. OECD Patent Statistics Manual. Paris: OECD Publishing.

Pisano, G. 2006. Profiting from innovation and the intellectual property revolution. Research Policy, 35(8): 1122-1130.

Pisano, G. P., \& Teece, D. J. 2007. How to capture value from innovation: Shaping intellectual property and industry architecture. California Management Review, 50(1): 278-+.

Raisch, S., Birkinshaw, J., Probst, G., \& Tushman, M. L. 2009. Organizational Ambidexterity: Balancing Exploitation and Exploration for Sustained Performance. Organization Science, 20(4): 685-695.

Reed, J. F., \& Stark, D. B. 1995. Robust analysis of variance - A simulation study. Journal of Applied Statistics, 22(1): 87-104.

Rockett, K. 2011. Property Rights and Invention. In B. H. Hall, \& N. Rosenberg (Eds.), Handbook of the economics of innovation, 1 ed., Vol. 1: 315-380. Oxford: North-Holland.

Schmoch, U. 2007. Double-boom cycles and the comeback of science-push and market-pull. Research Policy, 36(7): 1000-1015.

Schmoch, U. 2008. Concept of a Technology Classification for Country Comparisons. Karslruhe: Fraunhofer Institute for Systems and Innovation Research.

Scotchmer, S. 1996. Protecting early innovators: Should second-generation products be patentable? Rand Journal of Economics, 27(2): 322-331.

Stringham, E. P., Miller, J. K., \& Clark, J. R. 2015. Overcoming Barriers to Entry in an Established Industry: TESLA MOTORS. California Management Review, 57(4): 85-103.

Suarez, F., \& Lanzolla, G. 2005. The half-truth of first-mover advantage. Harvard Business Review, 83(4): 121-+.

Swift, T. 2016. The perilous leap between exploration and exploitation. Strategic Management Journal, 37(8): 1688-1698.

Tang, J. P. 2011. Technological leadership and late development: evidence from Meiji Japan, 1868-1912. Economic History Review, 64: 99-116.

Teece, D. J. 1986. Profiting from technological innovation - Implications for integration, collaboration, licensing and public-policy. Research Policy, 15(6): 285-305.

Teece, D. J. 2017. Towards a capability theory of (innovating) firms: implications for management and policy. Cambridge Journal of Economics, 41(3): 693-720.

Tellis, G. J., \& Golder, P. N. 1996. First to market, first to fail? Real causes of enduring market leadership. Sloan Management Review, 37(2): 65-75.

Trajtenberg, M. 1990. A penny for your quotes - patent citations and the value of innovations. Rand Journal of Economics, 21(1): 172-187.

Tushman, M. L., \& Oreilly, C. A. 1996. Ambidextrous organizations: Managing evolutionary and revolutionary change. California Management Review, 38(4): 8-\&.

Uotila, J., Maula, M., Keil, T., \& Zahra, S. A. 2009. Exploration, exploitation, and financial performance: analysis of S\&P 500 corporations. Strategic Management Journal, 30(2): 221-231.

Utterback, J. M. 1974. Innovation in industry and the diffusion of technology. Science, 188: 620-626.

Verhoeven, D., Bakker, J., \& Veugelers, R. 2016. Measuring technological novelty with patent-based indicators. Research Policy, 45(3): 707-723.

Wernerfelt, B. 1984. A resource-based view of the firm. Strategic Management Journal, 5(2): 171-180.

Wernerfelt, B. 2005. Product development resources and the scope of the firm. Journal of Marketing, 69(2): 15-23.

Wilcox, R. R. 2007. Robust ANCOVA: Some small-sample results when there are multiple groups and multiple covariates. Journal of Applied Statistics, 34(3): 353-364.

Wilden, R., Hohberger, J., Devinney, T. M., \& Lavie, D. 2018. Revisiting James March (1991): Whither exploration and exploitation? Strategic Organization, 16(3): 352-369.

Yu, Y. N., Wu, W. J., Zhang, T., \& Liu, Y. C. 2016. Environmental catching-up, eco-innovation, and technological leadership in China's pilot ecological civilization zones. Technological Forecasting and Social Change, 112: 228-236. 


\section{Appendix 1: History of digital data transport}

Table 4-7: A brief history of digital data transport towards ADSL for Internet Access

Period Technology

19th-20th century

Analog telephony, telephone signals transport through copper wires

1960s-early 1970s

Voiceband modems, digital data transport via telephone networks

End 1970s

Pulse code modulated (PCM) trunks, digitalization of the telephone networks interconnecting central offices

Early 1980s

Integrated Services Digital Network (ISDN), integration of speech and data on the same line (64 kbits/s), enabling services such as digital telephone, telefax teletext, and videotext

Broadband ISDN, involving higher data transmission speeds (144 kbits/s) with

1980 s Asynchronous Transfer Mode (ATM) technology for both synchronous voice and asynchronous data services on the same transport

Early 1990s

ADSL, allowing even higher data transmission speeds through copper wire (1.5 mbits/s)

Early 1990s

ADSL for Video On Demand

Mid 1990s

ADSL for Internet access 


\section{How Alcatel outperformed Ericsson in its ADSL innovation journey'}

1 This chapter is based on the working papers: Geerts, A., Visscher, K., de Weerd-Nederhof, P.C. \& Van Looy, B. (2012). The interplay of technological capabilities and organizational practices in highly uncertain environments - A comparative case study of the development of ADSL. Paper presented at $19^{\text {th }}$ International Product Development Management Conference, Manchester (United Kingdom), June 17-19 2012.

Geerts, A., Visscher, K., de Weerd-Nederhof, P.C. \& Van Looy, B. (2014). Resolving conflicting requirements in the management of technology and innovation - Insights from a comparative case study of ADSL technology. Paper presented at $4^{\text {th }}$ International Conference on Industrial Engineering and Operations Management, Bali (Indonesia), January 7-9 2014. 


\section{Abstract}

Management of innovation alongside current business activities is one of the key challenges faced by incumbent firms. Uncertainty combined with multiple, often paradoxical demands, makes organizing for innovation a difficult endeavor. How can incumbent firms effectively pursue innovation? How do top management teams and project managers influence the innovation trajectory when a new opportunity arises? What are the important decision moments and decisions? This chapter presents an in-depth longitudinal comparative case study of two incumbent firm's innovation journeys in the telecommunications equipment industry when Asymmetric Digital Subscriber Line (ADSL) technology presented itself as a new opportunity. Our goal is to unfold the process of an incumbent firm's efforts to construct and implement an effective innovation journey. We identify four key time periods: opportunity recognition, exploring the opportunity, enacting the opportunity, and commercialization of the technology, and five components which are closely related to each other: organizational design, people, resources, operational flexibility and capabilities. Incumbent firms should be aware of these phases and components, their interrelatedness and the fact that an innovation journey is to a certain extent subject to path dependency. While prior research tends to focus on a particular theory or perspective, this study reveals how different concepts - advanced by different scholars - are simultaneously present and influence each other. As such, our findings suggest the relevance of an encompassing perspective whereby eventual outcomes are the result of a multiplicative rather than an additive nature. 


\section{Introduction}

Firms are more than ever forced to be responsive and continually innovative. Innovation is one of the most important explanatory elements for long-term growth and firm survival (Cucculelli \& Ermini, 2012; Schumpeter, 1934; Spescha \& Woerter, 2019). Organizing for innovation is far from easy. Firms need to exploit the present and simultaneously explore the future. As such, effective innovation strategies encompass multiple objectives, which is especially challenging for incumbent firms that face the threat of new entrants (Bergek et al., 2013). While incumbent firms are in a stronger position to exploit innovation due to the availability of resources (Christensen \& Bower, 1996; Schumpeter, 1950), innovation scholars seem to suggest that incumbents may fall short in responding to opportunities for innovation due to inertia, the lack of (short term) economic incentives, and embeddedness within an established industry network (Tripsas \& Gavetti, 2000; Tushman \& Anderson, 1986; Utterback, 1994). Yet, according to several scholars, established firms are able to counter these innovation barriers by adopting an adequate organizational design that is characterized by differentiation (Burgelman, 1983; Christensen, 1997; O’Reilly \& Tushman, 2004); and by installing needed roles (Roberts \& Fusfeld, 1980), which enable the entrepreneurial dynamics that are typical for new entrants. However, a differentiated organizational structure and the installment of appropriate roles are not sufficient to bring incumbents at par with new firms entering business. The enactment of resources is crucial, since incumbent firms typically own relevant (complementary) assets (Cohen \& Tripsas, 2018; Tripsas, 1997). Only to the extent that established firms can access and mobilize available corporate resources, while fulfilling the requirements of structural differentiation and roles, organizing for innovation can become really beneficial (Sirmon et al., 2011; Van Looy, Martens, \& Debackere, 2005).

Insights into the mechanisms how firms can reallocate resources and reconfigure assets to simultaneously engage in innovation activities and exploitative acts related to the current business are relatively scarce (O’Reilly \& Tushman, 2011). Although process thinking is an emerging trend in organization studies, relatively few scholars apply a process perspective in studying innovation management (Janssen, Stoopendaal, \& Putters, 2015; Van de Ven, 2017; Vuori \& Huy, 2016).

Within this paper, we examine how incumbent firms can effectively organize for innovation. Moreover, we ask: How can incumbent firms effectively pursue innovation of a novel nature? How do executives and project managers influence the innovation trajectory when a new opportunity arises? What are the important decision moments and decisions? Relying on an in-depth longitudinal comparative case study, our research describes and disentangles the process an incumbent firm's efforts to construct and implement an effective innovation journey. In the early 1990's, Alcatel and Ericsson jumped on the bandwagon of a new technological opportunity, Asymmetrical Digital Subscriber Line (ADSL), which allowed fast data transmission over copper telephone lines. Both established telecommunication equipment firms recognized the innovation opportunity and engaged in their own innovation journey towards the development and commercialization of ADSL.

This study contributes to the technology and innovation management literature. We identify five crucial components for an effective innovation journey which are closely related to each other: 
organizational design, people, resources, operational flexibility and capabilities. Both scholars and practitioners should be aware of these components, their interrelatedness and the fact that an innovation journey is to a certain extent subject to path dependency. While prior research tends to focus on a particular theory or perspective (e.g. Srivastava \& Gnyawali, 2011; Westerman, McFarlan, \& Iansiti, 2006), this study shows how the different innovation management theories are interlinked.

Our findings confirm the relevance of organizational arrangements of a differentiated nature in the context of innovation. The effective pursuit of an innovation of a more novel nature entails the configuration of critical ingredients that show a sophisticated interplay. Besides (selective) senior management commitment and the presence of an entrepreneurial champion, we find evidence that hybrid organizational designs characterized by semi-permeability contribute to effective leveraging of corporate resources and successful exploratory efforts. We also show the importance of operational flexibility throughout the whole innovation process. Moreover, our findings seem to suggest that this flexibility is better enacted within hierarchies (rather than via markets). Management commitment and managerial decisions on both top management and project level seem to be of major importance for both developing a strategy and the actual innovation journey. They have a critical impact on resource allocation, capability building and use, and method. We identified four key time periods in the innovation journey: opportunity recognition, exploring the opportunity, enacting the opportunity and commercialization of the technology. We also identified five components that are closely related to each other and the period in which each component is particularly important.

Our study reveals that while people have an important role throughout the whole innovation journey, the most important managerial decisions occur in the second and third phase. Opportunity recognition usually occurs bottom-up, beyond sight of top management. The decisions that are made in the second phase, exploring the opportunity, form the basis for a successful innovation trajectory. A lack of commitment and managerial support will destroy the innovation opportunity. In contrast, commitment and support enable the exploration of the opportunity, which sets the stage for the third phase, enacting the opportunity. Managerial decisions in this phase determine how fast an innovation journey can proceed, taking into account the occurrence of unforeseen circumstances. Finally, the innovation journey results in the commercialization of the innovation.

In the next section, we present the research method, followed by a thorough description of the cases and their innovation journeys of ADSL. We then link our case data to theory. Finally, we discuss the theoretical and managerial implications, the limitations, and future research directions. 


\section{Research method}

\subsection{Research setting and design}

Our aim is to build a more integrative perspective on organizing for innovation alongside current business. Although various methods of case study research exist (Yin, 2009), we chose for the longitudinal comparative case study method because it enables thorough examination of multiple sources and loops of causation and relatedness (Pettigrew, 1990) which is highly relevant for identifying patterns in the process of innovation management. In order to elaborate theory, we build on chapter three and focus on a context that could serve as an example for incumbent firms operating in high-velocity environments, characterized by intense competition and products that are technologically advanced. We study the innovation journey of the Asymmetric Digital Subscriber Line (ADSL) technology within two incumbent firms in the telecommunications equipment industry: Alcatel and Ericsson. ${ }^{35}$ In particular, we opted for polar types in our sampling approach: one case of successful innovation performance and one unsuccessful case. The outcomes are different, but the antecedents or start position (in terms of resources - scale and scope) are similar, giving a quasi-experimental flavor to the design. Whereas Alcatel immediately became and remained market leader for subsequent years, Ericsson never got any significant market share despite their technological efforts. ${ }^{36}$ Polar type sampling has been found to result in clear pattern recognition of the principal constructs, relationships, and logic of the studied topic (Eisenhardt \& Graebner, 2007).

Alcatel and Ericsson are global corporations that provide telecommunication solutions to service providers, enterprises, and governments, enabling the deliverance of voice, data, and video telecom services. In the period under study, Alcatel employed on average 190.000 people and Ericsson 82.000 people. Both firms had operations in more than 100 countries. $^{37}$

In the early 1990s, Alcatel and Ericsson explored the promises of the ADSL technology. Following the ideas of Cioffi, who suggested already in 1979 that copper wires have the potential for much higher data transmission capacity, Alcatel and Ericsson began their innovation journey towards successfully developing and deploying the ADSL technology. ADSL became marketed as a product enabling telecom providers to service customers looking for Internet access. This technological innovation had a considerable impact on the telecom industry and became the most common technology for Internet access offered to home users in the beginning of the $21^{\text {st }}$ Century. Figure 5-1 shows the market popularity of ADSL compared to other technologies for Internet access.

35 ADSL is a data communications technology for fast data transmission over copper telephone lines that enables broadband access to the Internet.

36 See chapter three about market leadership and technological leadership in ADSL technology.

37 In 2006, Alcatel became Alcatel-Lucent after a merger with Lucent technologies. In 2016, Nokia acquired Alcatel-Lucent and merged it into the Nokia Networks division. 


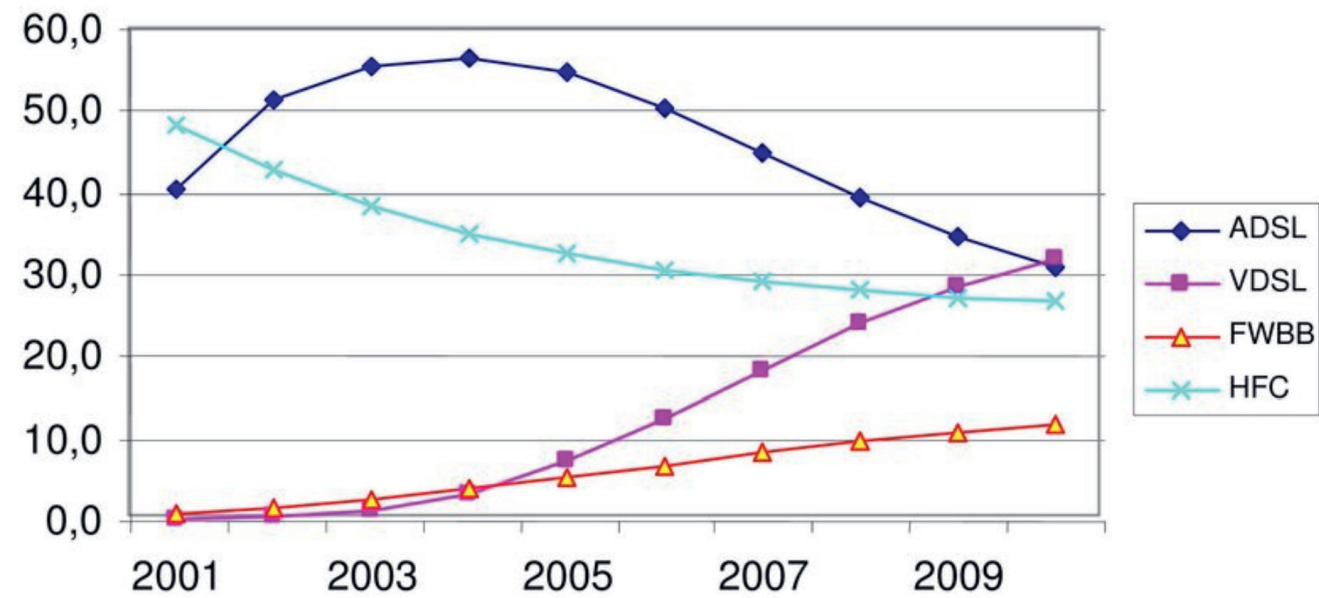

Figure 5-1: European market share distribution of ADSL, VDSL, FWBB and HFC38,39

\subsection{Data collection and analysis}

This study relies on retrospective cases since the effective development of ADSL started in the early 1990s and continued heavily until stages of technological maturity were reached in the first decade of 2000. Retrospective data collection allowed for overcoming the barriers of secrecy which are especially present when aiming to capture a firm's complete technological innovation trajectory. Different data collection approaches were applied in order to limit bias. First, we triangulated our data by using diverse data sources: interviews, documents, e-mail correspondence with key informants and free-form discussions (Eisenhardt, 1989). Second, in order to minimize the risk for retrospective sense making, we interviewed informants from different hierarchical levels who were actively involved in developing the ADSL technology and juxtaposed their accounts with information extracted from historical documents. Our informants viewed the innovation trajectory from diverse perspectives (Eisenhardt \& Graebner, 2007). Finally, to reduce the risk of cognitive bias and impression management, we asked informants to think about concrete events rather than considering abstract concepts (Miller, Cardinal, \& Glick, 1997).

The empirical study began in mid-2010 and continued to the Summer of 2012. A critical challenge in qualitative data collection pertains on how to move from surface levels to deeper levels of analysis (Pentland, 1999). Therefore we applied three stages in our data collection process. First, we conducted unstructured interviews with an involved R\&D manager and engineer of Alcatel in order to obtain initial information about the history and characteristics of the ADSL technology. In addition, we studied documents and books in order to get to know the technology and industry

38 Adapted from 'Traffic forecasts models for the transport network' by K. Stordahl \& B. Olsen, 2002, Networks, Retrieved from https://slideplayer.com/slide/12807169/

39 VDSL = Very high speed digital subscriber line; FWBB = Fixed Wireless Broadband; HFC = Hybrid fibercoaxial 
dynamics at that period in time (Bingham, 2000; Goralski, 2002; Summers, 1999). Furthermore, we examined publicly available information of Alcatel and Ericsson (i.e., press releases, annual reports) and we gained access to internal documents (i.e., reports of technical meetings, reports of steering meetings, contracts), representing a total of more than 1,700 pages. For each firm, we composed a graphical model of the chronology of the major events in the innovation trajectory of ADSL. Second, during multiple visits at Alcatel (Alcatel-Lucent, Belgium) and Ericsson (Sweden), we conducted 30 semi-structured interviews with engineers and managers at all hierarchical levels who were involved in the development of ADSL. Almost all interviews happened individually, face-to-face. The interviews lasted approximately one and a half hours and followed a protocol that evolved with the research project. In general, the questions were structured according to the chronology of the critical events that occurred in the innovation journey of ADSL. Additional "why" and "how" questions were asked to get an in-depth understanding of the complete ADSL development process, including entrepreneurial dynamics and resource allocation processes. The interviews were taped and transcribed, followed by a reexamination of the available documents to verify if there was consistency between the interview data and document data. In case of discrepancies or opaqueness, informants were asked to answer additional questions. To complete this second stage, we did a within-case analysis and wrote a detailed report for each firm (Eisenhardt, 1989). Our key informants subsequently received the report and provided feedback via electronic mail or face-to-face. In the third stage, we specifically focused on the differences and similarities in the approaches of Alcatel and Ericsson. We applied an inductive approach and turned our focus towards linking data and theory. We conducted a first-order and second-order analysis of the data (Van Maanen, 1979). The first-order analysis was built upon the information gathered from the interviewed persons. We did an in-depth content analysis and developed a visual representation of the ADSL innovation process in each firm, which we discussed thoroughly in order to figure out our interpretations. The results of this first-order analysis are described in the next section. In order to explicitly address our research questions, we moved to a more theoretical second-order analysis which encompassed examination of the data and first-order findings. We identified connections between our initial core concepts (i.e., organizational design, critical roles, entrepreneurial dynamics, corporate sourcing) and permitted more relevant concepts to be included. This step was followed by a new discussion round to compare and integrate our insights. Our second-order analysis resulted in a process model of organizing innovation alongside current business.

\section{The ADSL innovation journeys of Alcatel and Ericsson}

In this section, we describe and analyze the innovation process of ADSL within the two studied firms. For each, we start from the technological opportunity recognition until the commercialization of ADSL. Figures 5-2 and 5-3 summarize the critical events in the innovation 
process at Alcatel ${ }^{40}$ and Ericsson ${ }^{41}$. Figure 5-4 entails the innovation process models. We identified four distinct periods in time. The first entailed recognizing the opportunity, in which both firms realized the value of ADSL technology. The second phase is exploring the opportunity, in which both firms had to identify what they could do with the technology. How did it fit their strategy and would an investment in ADSL pay-off for them? The third phase shows how both firms enacted the opportunity, once they realized they would miss the boat if they did not act. The last phase is the commercialization of the technology, in which both companies tried to capture and increase their market share.

\section{Recognizing the Opportunity at Alcatel}

Long before someone was thinking about ADSL, in the 1980s, Alcatel focused on developing a technology called Integrated Services Digital Network (ISDN) and its accompanying Broadband ISDN architecture. ISDN enabled the integration of speech and data on the same line. This made services possible that were additional to voice (telephony), such as digital telephone, telefax, teletext, and videotext (Annual Report 1986). While development efforts in ISDN continued, engineers at Alcatel believed in the early 1990s that the maximum capacity of data transmission over copper wire had been reached with Broadband ISDN (144 kbits/s).

Within the framework of a cooperative R\&D agreement with Bellcore, Alcatel's manager of the central research division in Antwerp, Belgium - MdP - and its senior advanced system engineer - WV - visited the U.S. in 1990. Bellcore was exploring the potential of a new technological opportunity, ADSL, under the impetus of Joseph Lechleider, who strongly believed in the ideas of John Cioffi, who suggested already in 1979 that by using a wider range of frequencies, a data transmission capacity of 1 to 2 megabits/second would be feasible. During this visit, Bellcore researchers demonstrated that a much higher transmission over copper wire was possible; more than ten times the assumed maximum capacity by using Broadband ISDN. Both MdP and WV were enthusiastic about what they observed at Bellcore:

"I remember that the model of Bellcore allowed 1,5 mbit to be transmitted over a copper wire. That was a huge amount, but the technology was obviously not ready for commercialization yet. The idea that you can actually send that amount of data over copper wire was inspiring and we wanted to do research on whether even more could be achieved" (Manager of the central research division, MdP).

Upon returning to Antwerp, MdP proposed to senior management within Alcatel to start a small research program - within Alcatel's central research unit - on these new possibilities for data transmission over copper wire, focusing on ADSL.

40 Established in 1898, Alcatel has been at the center of telecommunications since the initiation of the industry in the late 19th century. Alcatel designs, manufactures, and markets complete telecommunications systems. In 2016, Alcatel-Lucent was acquired by Nokia. Alcatel-Lucent now belongs to the Nokia Networks division.

41 Ericsson was founded in 1876 as a Swedish telegraph equipment repair shop and became incorporated in 1896. Ericsson became a world leader in telecommunications equipment. 
"When MdP came back from the United States, he was convinced of the potential of ADSL and believed that it could really turn out to become something" (CEO Alcatel Antwerp, JdW).

\section{Recognizing the opportunity at Ericsson}

In the 1980s, Ericsson was also putting efforts in the development of Integrated Services Digital Network (ISDN). Broadband ISDN was became a major development project during the early 1990s, although the market was not ready yet for the technology during the 1980s. While development in ISDN continued, Ericsson's researchers got in touch with the ideas of ADSL through attending conferences in 1990. Ericsson's engineers picked up this new technology as a potential interesting opportunity. The company decided that its research labs had to start exploring ADSL more in-depth.

"The first time I heard talk about ADSL was during the Spring of 1990. Our research staff was participating in conferences and there we came in touch with activities concerning ADSL. I remember that there was great skepticism about whether ADSL would work, due to the challenges provoked by using old cables. But some of our research labs started to consider ADSL more in-depth. It was however no major focus at that point of time" (Program manager broadband access, PS).

\section{Opportunity recognition}

In this first phase, both Alcatel and Ericsson engaged in exploratory activities in order to figure out whether it would be worthwhile to further invest in the development of ADSL. Alcatel and Ericsson followed a rather similar strategy in the first phase of recognizing the opportunity of ADSL. Within both companies, the potential of the new technology was recognized by technical staff members and Alcatel's manager of the central research unit. They believed in the technology and communicated their vision to senior management who enabled the opportunity recognition. Senior management supported the ideas of their staff members and research towards ADSL was set up within the existing structures. However, confronted with uncertainty, as neither Alcatel nor Ericsson exactly knew what the future would bring, both companies kept options open and simultaneously explored different technological solutions for broadband access.

At this point in time, both firms behave very similarly and have a very similar starting position in terms of firm size, capabilities, and market access.

\section{Exploring the opportunity at Alcatel}

Prior to the discoveries at Bellcore, Alcatel already pursued research in optical fiber and COAX cable technologies for broadband access. Both technologies enabled much faster data transmission than Broadband ISDN, and were regarded as promising new access technologies. Confronted with these competing technological options, Alcatel decided to maintain a broad technological portfolio. To explore these technologies, they formed - in 1992 - a dedicated broadband research program, within the central research department.

"In the early 1990s, we were questioning in the R\&D unit whether DSL would actually become a technology breakthrough. We were putting efforts in technology to use copper wire for data transmission, but also fiber and COAX cable were on our work schedule" (R\&D manager, RD). 
The potential exploitation of ADSL on a large scale, required the development and adoption of standards on the level of a line coding technique, a technique that enabled the actual transmission of data by determining how bits are being sent (Chen, 1999). Alcatel decided to focus its efforts on the CAP (Carrier less Amplitude Phase) line coding technique. However, in 1993, the American National Standards Institute chose the competing DMT (Discrete MultiTone) as the standard for ADSL (standard T1E1.4), in which it was followed by International Telecommunications Union and European Telecommunications Standard Institute. To comply with the new standard, Alcatel had to reorient their work towards DMT. In particular, they had to develop new chips to enable this line-coding technique. The chips were developed in close cooperation with Alcatel's own chip division - Mietec. With the support of senior management, resources were quickly mobilized over 100 full time equivalents - for the development of these chips. The efforts were productive. In about six months, they were at the same level as with CAP before, and in 1995, the first workable DMT chipset for ADSL was finished. This was fast compared to Alcatel's competitors, such as Motorola, forecasting their DMT chip release for 1997 (Tzuo, 2004).

In the early 1990s, the foreseen 'killer application', i.e. a single application with such an expected large market demand that it justifies the creation of a service or system (Starr, Cioffi, \& Silverman, 1999), for broadband access technologies was Video on Demand (VOD). VOD would enable customers to order videos at the moment of their choice, through a broadband access network. Alcatel started the development of VOD with ADSL and fiber in 1993. In 1995, Alcatel was ready for the first release of an ADSL system for the delivery of VOD (Galatioto, 1996). However, in the last months of 1995, the great expectations for Video on Demand collapsed. An Alcatel engineer concluded:

"The technology was not mature enough, therefore in order to make the product profitable, the tariffs would have been too high. And although the idea was great, the market was not ready for VOD" (Engineer, YG).

At the time that VOD became questioned as killer application, another potential application the Internet - started to gain momentum.

\section{Exploring the Opportunity at Ericsson}

While the ideas of ADSL were introduced, efforts were made to examine two other promising access technologies, optical fiber and COAX, that enabled much faster data transmission than Broadband ISDN. Ericsson deliberately choose to have a wide technological broadband access portfolio in which research focused on fiber, COAX, ADSL and foreseen upcoming wireless access technologies.

In 1993, DMT was chosen as the international standard for ADSL. Ericsson had to include specific DMT chips in their ADSL solutions in order to have their ADSL system compliant with the industry standards. Ericsson did not produce these chipsets themselves but rather relied on an external supplier, Motorola.

In 1994, a broadband access program was developed within a newly created broadband business unit. The program - responsible for development, production and sales - was managed 
by a program manager and included design centers in five European countries. The design centers were led by an R\&D manager based in Stockholm (Sweden). These centers were Ericsson companies or firms with whom Ericsson was cooperating.

"We had 550 people assigned to the broadband access program, this was a lot. We had few other programs as well in this division, but the broadband access program was the largest" (Program manager broadband access, PS).

The geographical spread of its design activities came along with some coordination costs. Ericsson aimed to research and develop the different access technologies simultaneously, since no one could predict what the preferred access technology would be in the future. Besides the fixed technologies, senior management insisted on including a focus on wireless technologies too. During the following years, Ericsson took decisions to cancel further development efforts if the access technology was not expected to be successful. Consequently, different technology development tracks were stopped:

"We kept all options open and tried out a lot of access networks. In the end, the only ones that really resulted in a product were ADSL and microwave system, all other development paths were cancelled throughout the years" (R\&D manager broadband, AS).

Ericsson accomplished partnership agreements and acquisitions according to the guiding principle of where the required capabilities could be found. The company aimed to strengthen its technology and market position in the access network area through collaboration with external partners. Of major importance for the ADSL development was Ericsson's buyer-supplier relationship with Motorola. Motorola's chip manufacturing efforts were focused on their brand new 'turning copper into gold' concept. Although the Swedish Ericsson division was not totally convinced about Motorola's ADSL chipset technology, the Austrian division of Ericsson, Ericsson Schreck, committed to Motorola and its promising CopperGold ADSL transceivers. The Motorola CopperGold chip was promised to be the best in its range and it would make Ericsson's ADSL product competitive (Newswire press release, 12 June 1996).

\section{Exploring the opportunity}

During the exploring phase, the two firms started to diverge with regards to the innovation journey followed. Alcatel relied on internal resources for the exploration of ADSL. The company had its own chip manufacturing division, which played a critical role in the development of the new technology, as ADSL solutions required a particular/dedicated chipset. In addition, Alcatel's exploratory activities were concentrated in Antwerp. Ericsson applied a different approach. Exploratory efforts occurred in Austria and Sweden. Ericsson relied on their own resources in combination with the supply of external components. As Ericsson did not have a chip division, buyer-supplier arrangements were made with Motorola for the delivery of a high performing ADSL chipset, an essential component in Ericsson's ADSL solution. In addition, with the aim of strengthening its technology and market position, Ericsson opted for partnership agreements and acquisitions with firms that possessed stronger capabilities than Ericsson had. 


\section{Enacting the opportunity at Alcatel}

One of the main advocates to focus on the emerging internet technology at Alcatel was MdP, the manager of central research. He initiated a minor research program focusing on internet technology within the central research unit in 1993.

"At the moment that I was in charge of ADSL, I clearly communicated: "ADSL, fine, but not any longer for video. We should focus on ADSL for the Internet". This resulted in a serious discussion at the firm level. The Internet was not really successful yet. In addition, the mindset was still on VoD. The central debate was: "Can we work that much for the Internet, and not for Video?". I had to push hard, together with $\mathrm{WV}$, in order to put Video aside. There was a lot of pressure from above: so much investments had been made in Video, we cannot stop this.... I had to lobby in a severe and tough way" (Manager of the central research division, MdP).

Two years later, it became part of the corporate strategy.

Given the competition of the cable companies (COAX), telecom operators were under pressure to offer similar access capacities. They were looking for an access technology that would enable greater capacity without costly and time-consuming upgrades of the current network (Tzuo, 2004). Implementing optical fiber would be too costly and time-consuming. Therefore, ADSL that made use of the existing copper lines was the most viable solution to compete with the cable companies.

The manager of the central research division, MdP, feared considerable delays if ADSL would have become part of the existing business unit (S12). To further develop ADSL technology for internet usage, Alcatel set up a semi-autonomous unit under strong impetus of $\mathrm{MdP}$, which they named a virtual company ( $\mathrm{VC}$ ). The $\mathrm{VC}$ was an organizational unit within the boundaries of Alcatel. It had an autonomous position and was allowed, for instance, to determine its own purchase and $\mathrm{HR}$ policies. Employees of the VC were attracted from the central research department, but also from the Switching division.

"The VC was an independent structure within Alcatel. We received quite some freedom, but were allowed to use the basic facilities within Alcatel. Based on my experience with Broadband ISDN, I was convinced that if we want to make some money out of ADSL fast, we should manage it independently from our telephone switch system." (Manager of the central research division, MdP).

To pursue the ADSL goals, MdP and his colleagues received support from members of the senior management team. Especially the general manager of Alcatel in Antwerp (Belgium), where the central research division manager worked, and the $\mathrm{COO}$ in the headquarters in Paris supported the idea, while the CEO was 'deliberately' looking out of the window (he did not agree/ approve, but did not block/veto either). The decision to start the VC rather than to integrate it in the main Switching division was no evident decision, though:

"Switching dominated everything, thus also new developments. Normally these had to be integrated in switching. It was obvious that if we were to leave it to the Switching 'machine' that it would take too long. We needed people. And the manager of the central research division believed in it. The idea was a virtual company, away from Switching. These were heroic discussions, and absolutely not evident" (CEO Alcatel Antwerp, JdW). 
Support for large investments in ADSL was not evident at all on a corporate level. Some countries preferred fiber or the old installed ISDN base instead of demanding ADSL.

"Stop with ADSL! That was the argument we heard a lot, the English, the Japanese and the Germans do not want it. What are you doing?!"(CEO Alcatel Antwerp, JdW).

Nevertheless, due to the perseverance and faith in ADSL by several key individuals in Alcatel, developments in the technology continued. MdP proved to be capable of igniting the enthusiasm for ADSL at top management level, giving ADSL a central place in the firm's strategy, and getting the support and resources needed to develop an ADSL architecture rapidly:

"MdP was the driving force, he was convinced about the value of ADSL and we actually followed his push. We thought: yes it could be... But MdP had a vision and we decided to take the risk" (IP specialist, GN). "He had charisma, employees wanted to work for this man" (CEO Alcatel Antwerp, $J d W)$.

\section{Enacting the Opportunity at Ericsson}

As Video on Demand (VoD) was globally considered to be the promising application, Ericsson dedicated efforts towards the deployment of VoD. However, being confronted with the disappointing expectations of the foreseen broadband access 'killer application', and the idea that the market for broadband networks was not expected to pick up stream before the end of the century, Ericsson reoriented its development resources to areas where an active market already existed.

Although there were people, engineers and project managers who really believed in the ADSL technology, top management got not fully convinced. A lot of resources were dedicated towards research and development of wireless related access technologies at the cost of fixed access technology development:

"I remember that we had a lot of discussions about what could really take off. There were many people that did not believe in ADSL. We were introducing mobile broadband, which was very early. The messages were a bit competing. Was it going to be fixed or mobile broadband? This influenced resource allocation. We needed money to develop our own chipsets for ADSL, but we never got that far" (R\&D manager broadband, AS). "It was necessary to invest more in the fixed broadband access technology side. From that point of view, it was hard to be successful in this fixed technological area. Especially since senior management was dedicated to the wireless area, more than to the fixed area. They regarded the fixed broadband access field as 'old fashioned', nothing new would happen there. It would be just a temporary market..." (Program manager broadband access, PS).

Ericsson's broadband access unit experienced an unexpected event in their reliance on Motorola for ADSL chipset delivery. It turned out that Motorola was not capable of meeting the expectations in supplying the crucial chip component for Ericsson's ADSL end-to-end solution. Ericsson found an alternative supplier, Analog Devices. 


\section{Enacting the Opportunity}

After a few years of exploring the new technology, Alcatel and Ericsson decided that they had to regard ADSL as a new innovation project which included further development and commercialization in the end. Both companies faced the failure of the foreseen 'killer application', Video On Demand. However, instead of following the classical stage-gate model and quitting all efforts, Alcatel and Ericsson continued with ADSL developments. Both companies noticed the emergence of the Internet and the potential of ADSL in delivering Internet services.

Whereas this third phase started rather similar for both firms, differences appeared very soon after the introduction of this phase. A different organizational design was chosen to further develop the innovation towards a product that can be commercialized. The presence of the innovation champion and strong managerial commitment enabled the creation of a hybrid, semiautonomous, structure at Alcatel that was dedicated to the ADSL development. The autonomous ADSL business structure could make use of corporate resources whenever needed. It provided flexibility and enabled fast decision making. In contrast, Ericsson considered ADSL as one of the innovation projects within the broadband business unit where different technology programs had to compete against each other for management support and resources. This fully integrated structure did neither favor flexibility, nor enabled strategic autonomy or other entrepreneurial dynamics to unfold.

Alcatel also continued to rely on internal resources until commercialization of their endto-end solution, while Ericsson remained dependent upon external suppliers for the delivery of critical components in their ADSL product which caused them a delay.

The absence of an innovation champion and strong managerial support, the integrated structure and reliance on external suppliers at Ericsson, made it more difficult to go through this third phase than was the case with Alcatel.

\section{Commercialization of ADSL at Alcatel}

In 1996, a crucial moment for the whole industry in the emergence of ADSL-based internet technology occurred. Four American telecom operators formed the Joint Procurement Consortium (JPC) with the aim to jointly purchase ADSL equipment to offer internet services to their customers. JPC sent out a proposal request for ADSL to a number of solution providers, among which Alcatel. This request contained several technical specifications and a request for standard compliance. The solution providers had to deliver it to JPC on August 6, 1996. Three solution providers were shortlisted by JPC, namely Westell, Ericsson and Alcatel. Alcatel put a lot of effort into attaining the JPC contract, as it would give them the most prominent position in the ADSL market and a strong foothold in the United States, where Alcatel was still a minor player. During the JPC committee visit to Antwerp, Alcatel showed them their full ADSL architecture, which was an end-to-end solution.

On the 7th of October 1996, press releases announced that Alcatel had been selected by the JPC to deliver ADSL equipment. Alcatel was chosen as the preferred supplier for several reasons. They proved to JPC that they were capable of delivering a reliable, well priced, end-to-end ADSL solution. 
"A standardized ATM based end-to-end solution, pricing and interoperability were major factors that influenced the JPC decision. However, the four JPC members also acknowledged Alcatel's relative maturity of the product development, the low risk of obtaining the product on schedule that met the requirements, and the availability of a full featured element management system as crucial for granting the contract to Alcatel" (JPC Jury member, TS, Ameritech).

For Alcatel, winning the JPC turned out to be crucial. It gave them credibility in the market and an opportunity to enter a learning curve and reduce costs, which gave them a head start over the competition. The first ten-thousands of ADSL lines were shipped to the USA in 1998. However, real profits were realized only from 2000 onwards as a result of ineffective operations and supply chain management. Although Alcatel had extensive experience and assets related to production and distribution, the VC initially failed to make a proper use of it.

"We had very good ReD, but production, shipment, inventory, and working capital were an absolute disaster. Actually, we were a gang of amateurs and I think it was a stupidity; the company knew how to do the operations... If we had done that better, we would have earned much more money" (Senior Advanced Engineer, WV).

\section{Commercialization of ADSL at Ericsson}

In 1996, Ericsson delivered an ADSL proposal to the four American telecom operators that were granting a joint procurement consortium (JPC) contract to the best solution provider. Although a lot of companies provided an ADSL solution to the JPC, only Ericsson, Alcatel and Westell were shortlisted for the final round before the decision was made. The ADSL solution of Ericsson contained the brand new high-tech and very promising CopperGold chips from Motorola that were still under development. Unfortunately, Motorola's CopperGold chip turned out to be very complex, challenging and difficult to develop and implement. Motorola got a serious delay in delivering the chips to Ericsson and Analog Devices came upfront as the alternative supplier for Ericsson's ADSL proposal towards JPC. In hindsight, the R\&D manager concluded:

"It would have helped a lot if technical reviews from technical people within Ericsson made us understand that the Motorola concept would fail. Ericsson would then have envisaged technical alternatives (either another supplier or starting up internal development efforts) if such a technical review was available earlier on. Now, alternatives were started very (too) late" (R\&D manager broadband, AS).

It was a close call, but the JPC jury decided not to grant Ericsson the JPC contract. JPC declared that Ericsson had an interesting low price and by that Ericsson would have been the preferred supplier if only price was taken into account. However, the JPC decision was based on much more than the pricing argument.

"My team thought that the CopperGold chip was technically more advanced, but more risky. Motorola did not have working samples and it was a very complex mixed-signal type of chip. We guessed that it might take years for Motorola to get its chip working and our guess proved to be correct. Ericsson did communicate to us that they could substitute the Motorola chip by another type of chip in case Motorola would be further delayed. However, we thought that substitution 
would without doubt slow down Ericsson's progress and we preferred the fact that Alcatel controlled its own chip" (Chair technical committee JPC, NR, BellSouth).

Also, JPC noticed that Alcatel was more committed to ADSL in comparison to Ericsson:

"Alcatel's lab demonstration was more complete. It seemed clear that Alcatel was very committed towards ADSL. Ericsson's ADSL development was spread over multiple locations. We were not impressed that the daily horn blew, during our visit to Ericsson's facility in Vienna, indicating that is was now time for all employees (including the engineers) to go home" (Chair technical committee JPC, NR, BellSouth).

Although Ericsson did not get to enter the US market as ADSL technology supplier, they continued investments in ADSL. In 1997, Ericsson launched its first end-to-end ADSL solution on the market. Ericsson had a strong position in the supply of mobile systems and the market for public switches. In the second half of the 1990's, Ericsson was market leader for mobile data networks that would have a significant impact on wireless internet development. In contrast, the company had a remaining weak position in the market for traditional fixed data transmission and transport network products, such as ADSL.

\section{Commercialization of ADSL}

At the time of the American Joint Procurement Consortium (JPC) contest, Alcatel delivered a mature prototype of their ADSL end-to-end solution. Ericsson proposed an almost fully mature prototype. Both firms were in an almost similar position at the start of this fourth phase. While it should be regarded as a close call, since both companies had their prototype, the JPC jury decided to grant the contract to Alcatel. The jury considered Alcatel's ADSL to be more mature, they had doubts about Ericsson's reliance on Motorola and possible delays by choosing an alternative supplier, and they noticed the strong commitment of Alcatel. Granting the contract to Alcatel became the start of a monopolistic position in North America and subsequent worldwide market success of Alcatel's ADSL product. Alcatel became immediately market leader and managed to keep this position for the subsequent years. Ericsson never got any significant market share in the new ADSL market. ${ }^{42}$

42 See chapter 4 for a detailed overview of the ADSL market share from Alcatel and Ericsson. 


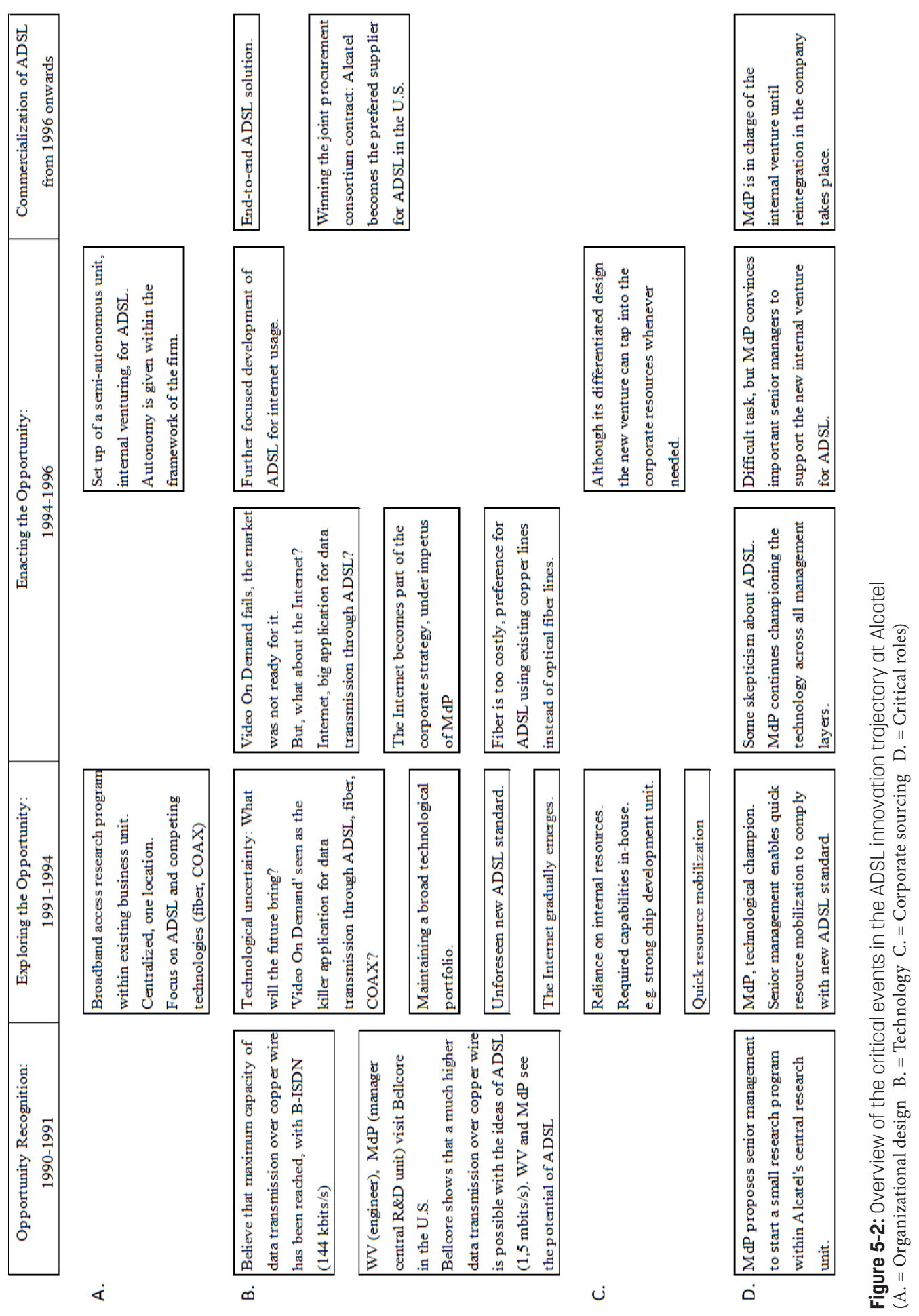




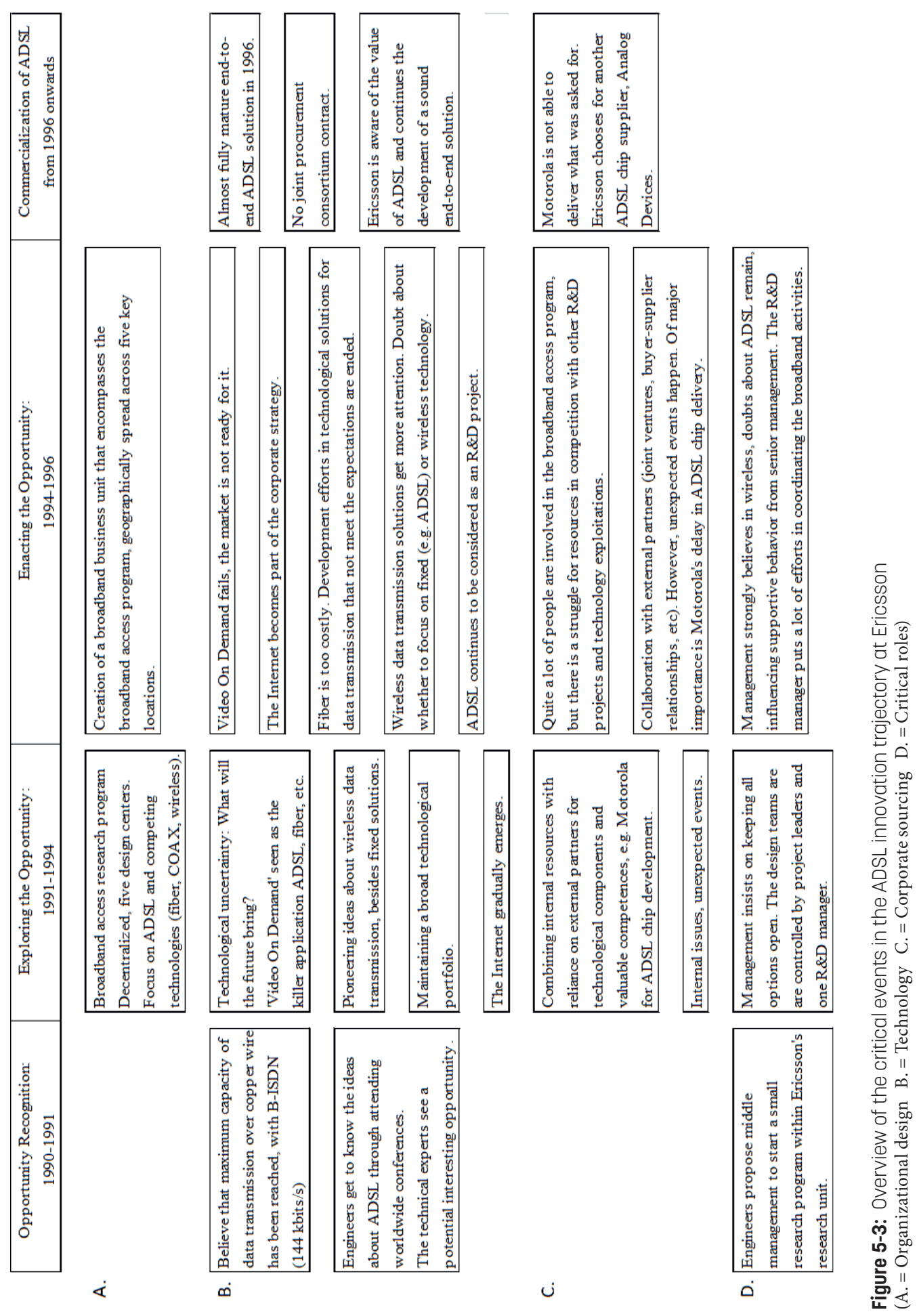




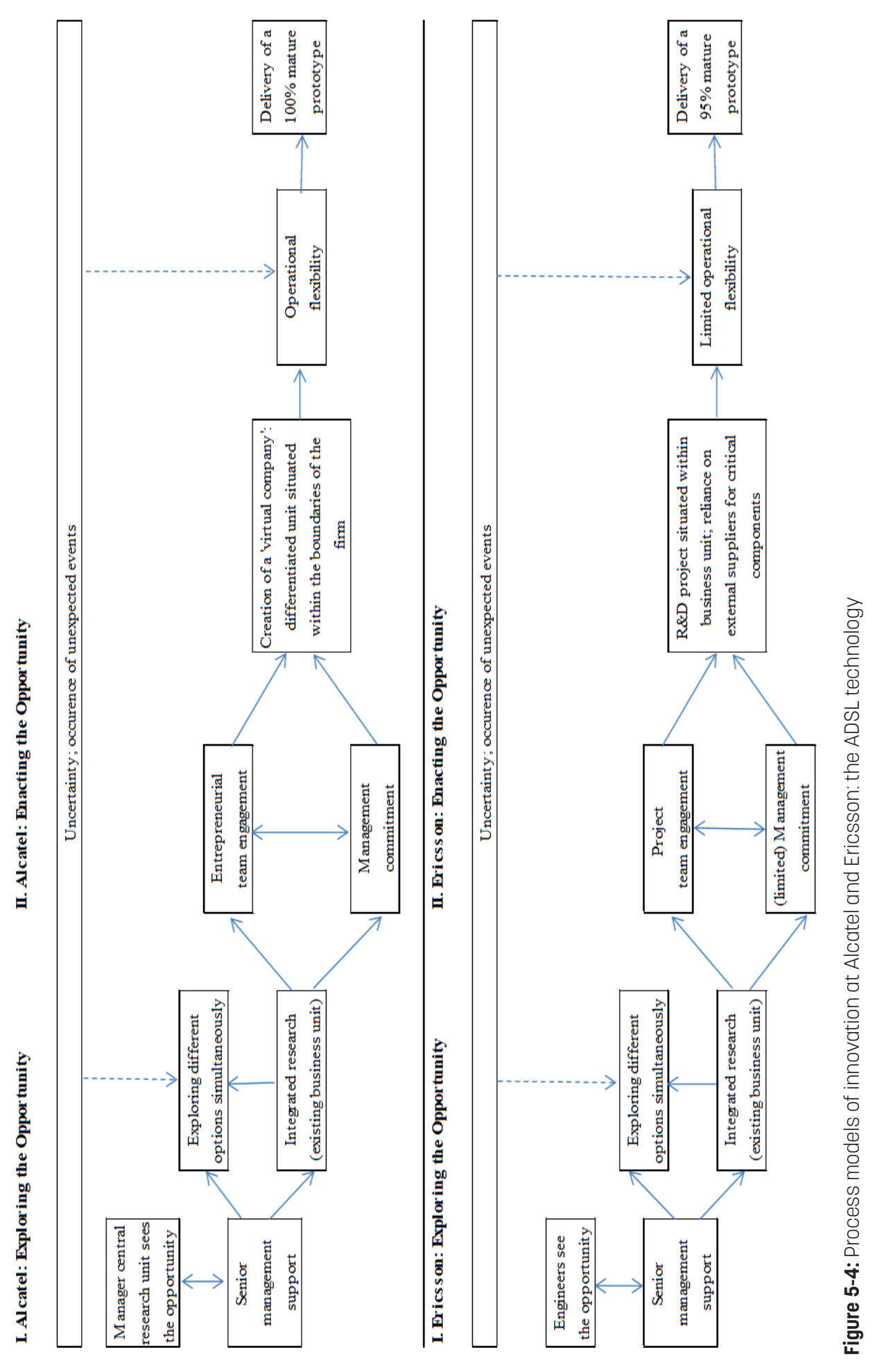




\section{Identifying the critical components of an effective innovation journey}

A large body of literature has analyzed the innovation behavior of incumbent firms and their performance (Rothaermel, 2001). This section relates our cases to different theoretical lenses present within the innovation management literature. Moreover, we link the actual innovation journeys of the studied firms to to the insights from theory. Whereas the innovation strategy involves the plan, the innovation journey is what actually happened. In figures 5-2 and 5-3, we analyzed the innovation journeys according to the core concepts that we had initially developed. Based on a thorough study of the data, we conclude that we should consider the following five components as being critical in an innovation journey: organizational design, people, resources, capabilities and operational flexibility.

\subsection{Organizational design}

Innovation brings a challenge in organization design for incumbents (Westerman et al., 2006). An increasing number of scholars stress the importance of differentiation between exploratory innovation activities and exploitation of the existing business. Developing new innovations require loose, organic structures which differ significantly from the need for controlled processes and strong task interdependencies for efficiency and exploitative improvement of existing business activities (Burns \& Stalker, 1961). Management practices that are most productive for exploiting existing business are regarded to be counterproductive for exploring radically new innovations (Christensen, 1997). Prior research asserted a connection between structural autonomy and innovation (Christensen, 1997; Tushman \& Anderson, 1986). Whereas various theoretical design recommendations exist, ranging from autonomous to integrated approaches, studies repeatedly demonstrate that structural differentiation, i.e. the separation of organizational tasks into different subsystems (Lawrence \& Lorsch, 1967), positively affects a firm's ability to exploit the present and explore the future (Gilbert, 2005; Lavie, Stettner, \& Tushman, 2010; O’Reilly \& Tushman, 2011). The strength of structural differentiation lies in its ability to handle multiple, often paradoxical demands that stem from the need to engage in innovation on the one hand, and the commitment towards proceeding with and improving the existing business activities on the other hand. The organizational design literature describes multiple organizational structures which allow for moderate to extreme differentiation between acts of innovation and the mainstream business (Tushman et al., 2010; Westerman et al., 2006). Consider for example, the creation of internal ventures (Burgelman, 1983), spin outs (Christensen \& Overdorf, 2000), and ambidextrous organizations (O’Reilly \& Tushman, 2004).

Our case studies suggest the relevance of a more nuanced view on organizational design. Neither solely differentiation nor solely integration seems to pay off in the context of innovation activities alongside current businesses. In fact, we find evidence for a hybrid organizational design that allows for both differentiation and integration. A hybrid organizational design allows to seize simultaneously the benefits of a large organization and a small entity. Alcatel created a hybrid 
structure for its ADSL development, which they called a "virtual company". Through, as it was, a semi-permeable membrane, the ADSL innovation project was able to benefit from the company's resources while being granted sufficient autonomy to be entrepreneurial in its own right. This was exactly what the innovation champion in Alcatel wanted to achieve. In contrast, Ericsson applied an integration strategy. They considered ADSL as one of the innovation projects and integrated the development process in a broadband business unit, along the other innovation projects that were related to broadband access technologies. This integration meant being subject to the hierarchical power of the large organization, being limited in autonomy and little opportunity for entrepreneurial dynamics.

The creation of a semi-independent and dedicated structure alongside the mainstream business is no straightforward decision for incumbent firms. Engaging in innovation and subsequent new business development includes uncertainty, risks and the - often extensive - use of resources. As our study illustrates, management is inclined to apply a project logic for new product development that should occur under full management control of the parent company and the involved business unit. Not meeting predefined targets has direct implications for the innovation project. This approach is often found to be detrimental for the innovation process due to reasons such as rigidity, risk aversion, political constraints, lack of commitment and complex decision processes.

The decision on whether or not and how to integrate the innovation project into the organizational structure of the firm is taken fairly quickly in the innovation process. Our data illustrates that this decision occurs in two phases: exploring the opportunity and enacting the opportunity. At the start of the exploration phase, a choice is made. In the transition from the exploration phase to the next phase, enacting the opportunity, either the firm sticks to its prior decision or the firm chooses a different organizational set up.

\subsection{People and roles}

While structural differentiation is often positioned in the literature as a success factor in organizing for new innovation, scholars follow the classical work of Lawrence and Lorsch (1967) by stressing the importance of integrative efforts for appropriating the potential value embedded in structurally separated activities (Jansen et al., 2009; Sirmon, Hitt, \& Ireland, 2007). In this respect, a critical function is given to senior management teams to enable integrative and synergetic value across the different units within the firm (Jansen, Kostopoulos, Mihalache, \& Papalexandris, 2016; Kor \& Mesko, 2013; O’Reilly \& Tushman, 2011). Although strong emphasis is given to senior executives, one cannot ignore the relevance of other role behavior functions in organizing for innovation alongside current business. In particular, scholars highlight the presence of a champion and entrepreneur which has been found to be closely related to the success of innovations (Baron, 2006; Beckman et al., 2012; Howell \& Higgins, 1990; Roberts \& Fusfeld, 1980).

Consistent with seminal work of Roberts and Fusfeld (1980), our findings show that the presence of critical roles which enable and support the innovation has a powerful impact on the process. Although prior research put strong emphasis on sponsorship and commitment of senior management (Garrett \& Neubaum, 2013; Jansen et al., 2009; O’Reilly \& Tushman, 2011), the 
cases of Alcatel and Ericsson accentuate relevant roles at different hierarchical levels. In addition, innovation opportunity recognition usually occurs bottom-up, beyond sight of top management. New product and business development often arises from a bottom-up process. The decision to engage in an innovation trajectory comes along with the formation of an innovation team that consists of specific team members. Within Alcatel, the presence of an innovation champion facilitated the transition of a project to a venture logic in which ADSL was viewed as a new business that had to be developed and commercialized separately from the existing business activities. This champion convinced top management to apply internal corporate venturing and to create a semi-permeable differentiated structure for the exploitation of the ADSL technology towards a marketable end-to-end product.

Our case studies show that management commitment and the presence of a champion that strongly support the innovation journey seem to make a difference. Alcatel's manager of the central research unit was the entrepreneurial champion for ADSL. Thanks to his drive and perseverance, the senior management team became eager to take up the challenge of committing strongly to the ADSL development. For the champion, it was already obvious at the moment of recognizing the opportunity, that he would become the driving force behind the ADSL innovation journey. In fact, he learned from prior experiences in which the firm encountered failure, that someone has to act as an entrepreneurial champion in order to maximize the chances on success. This suggests that people tend to learn from prior experiences which will influence their future role behavior. Ericsson did not have a champion role in the ADSL innovation journey. There was no 'leader' that acted as the driving force for ADSL. In addition and related to that, top management was not fully committed to ADSL. Instead they preferred investments in wireless broadband access technologies. As a consequence, obtaining the required resources for the innovation journey of ADSL was much more difficult in Ericsson compared to Alcatel. The presence or lack of management commitment clearly has a strong influence on resource flows towards the innovation project.

Our findings illustrate that the 'differentiation imperative' encompasses more than structure and senior executive involvement (Anderson, Tushman, \& O’Reilly, 1997). Organizing for innovation next to existing business activities also requires the presence of critical roles on different levels within the organization (Burgelman, 1983), differentiation which has an undeniable strong influence on the innovation process. While a firm can change leadership roles and shift focus and support over time for a project, it seems that the tone for the level of commitment to a technology is set very early in the process - at the opportunity recognition phase, when the innovation champion arises.

\subsection{Enacting resources}

Scholars frequently advance a resource-based perspective in explaining successful innovation (Danneels \& Sethi, 2011; Srivastava \& Gnyawali, 2011). The resource-based view of the firm suggests that a firm's ability to innovate and generate subsequent profits is a function of its resource endowments (Wernerfelt, 1984, 2013). Incumbent firms typically possess a large portfolio of corporate resources which are built through experience. Corporate resources are classified as 
"all assets, capabilities, organizational processes, firm attributes, information, knowledge, etc. controlled by the firm that enable the firm to conceive of and implement strategies that improve its efficiency and effectiveness" (Barney, 1991: 101).

Examining innovation behavior of incumbent firms, scholars concentrate in particular on the presence of complementary assets, which can give incumbent firms a significant competitive advantage over new entrants and incumbent competitors (Fuentelsaz, Garrido, \& Maicas, 2015; Rothaermel, 2001; Taylor \& Helfat, 2009; Teece, 1986; Tripsas, 1997). Complementary assets refer to the capabilities needed to support the successful commercialization of an innovation, other than the assets on which an innovation is build (Teece, 1986).

One of the key features of the need to carry out exploratory innovation activities alongside exploitation of the existing business is the ability of the firm to reallocate resources to address new opportunities and threats (March, 1991). The critical aspect of resource allocation has been illustrated in previous studies, showing that failed innovation efforts do not necessarily result from absence of technology or resources but the inability to allocate those resources effectively to the exploratory innovation effort (Gilbert, 2005; O'Reilly \& Tushman, 2011; Sirmon et al., 2011; Tripsas \& Gavetti, 2000).

The problem of efficient and effective resource allocation has been subject of discussion from the earliest times (Bower, 1986). Allocating resources to innovation projects is a burdensome responsibility for many organizational decision makers as they run the risk of misjudging the prospects of success (Klingebiel \& Rammer, 2014). Firms are confronted with uncertainty about what the future will bring in terms of technology and market, which results in practices of purposeful experimentation and subsequent demand for resources (Murray \& Tripsas, 2004). Research illuminates the relevance of simultaneous experimentation as an alternative approach to focused commitment in development trajectories of firms that operate under conditions of uncertainty (Andries, Debackere, \& Van Looy, 2013).

Research on cognition and capabilities suggest that a firm's development and deployment of resources is directly influenced by managerial cognition (Benner \& Tripsas, 2012; Eggers \& Kaplan, 2013). In this respect, Eggers and Kaplan (2009) stressed how the union between capabilities and the market cannot be made if managerial beliefs are not adjusted to the opportunity.

As the stories of Alcatel and Ericsson illustrate, innovation requires resources and access to the required resources depend on management commitment. It is not just about the money, it is also about being able to leverage staff, knowledge and complementary assets. Following the existing theoretical insights in the literature, our cases show that the choice of resource allocation strategy affects innovation performance. As our data from Alcatel and Ericsson illustrate, both firms were allocating resources to a broad range of innovation projects. Whereas they initially provided resources to multiple projects, i.e. resource allocation breadth (Klingebiel \& Rammer, 2014), Alcatel subsequently chose to discriminate between the ADSL project and the other projects and invested heavily in ADSL development. In contrast, Ericsson did not follow a resource allocation selectiveness strategy (Klingebiel \& Rammer, 2014) in favor of ADSL, as management preferred assigning resources to future wireless internet solutions. The hybrid organization structure in 
Alcatel allowed for a smooth resource flow of the headquarter to the "virtual company" that focused on ADSL development. Resources do not come very much into play till the enacting of the opportunity phase, where the firm needs to decide to "buy" or partner with other parties or to rely on internal capabilities to act upon the opportunity.

\subsection{Operational flexibility}

Although the implementation of a differentiated organizational design has proved to be beneficial for innovation trajectories alongside existing business activities, our findings show that this is not sufficient for effectively pursuing innovation. The case study of Alcatel and Ericsson demonstrate that operational flexibility is a critical success factor throughout the whole innovation process.

Innovation journeys often not follow a predefined route which can fully be controlled (Van de Ven, 2017). While a firm's innovation strategy entails the innovation plan, its actual implementation might be different compared to the strategy. Innovation comes along with uncertainty (Luthfa, 2019; Van de Ven, 2017). This uncertainty requires firms to be flexible along their innovation journeys (Van de Ven, 2017). Flexibility refers to "the capacity of an organization to efficiently and effectively redeploy/redirect its resources to value creating and value protecting (and capturing) higher-yield activities as internal and external circumstances warrant" (Teece, Peteraf \& Leih, 2016, p.9). Gaffard (1990) distinguishes two types of flexibility, response flexibility and action flexibility. Response flexibility is defined as the ability to adapt to exogenous and endogenous changes. Action flexibility refers to the ability to change.

Firms are to a large extent clueless about what the future will bring, what technologies will become important and how markets will react. Indeed, as both Alcatel and Ericsson did, it is wise to start from a planned strategy which encompasses the intention to engage in a particular innovation trajectory. However, an innovation process is far from linear. Our data shows how important it is to apply a flexible method in an innovation journey. This means that firms should include flexible reasoning in designing their innovation strategy. At first, ADSL technology was planned to be the technology for delivering Video On Demand. While Alcatel and Ericsson were busy with the development of ADSL for Video On Demand, the idea of the promising ADSL application collapsed. This was a major unforeseen event. However, Alcatel and Ericsson decided to reorient their efforts towards ADSL for the Internet. Along the ADSL innovation journey, both firms were confronted with unforeseen events. While Alcatel exhibited strong levels of flexibility, Ericsson was less flexible.

The degree to which these firms were flexible depended on their organizational design, resources, capabilities and commitment - the presence of entrepreneurial roles/champion and the team of technical 'wiz kids' the champion was able to mobilize. The hybrid ADSL business structure enabled a high degree of flexibility and fast decision-making while the integrated structure in Ericsson led to hierarchical pressure and limited flexibility in coping with unforeseen events. Closely related to the organizational design, is the ease and speed with which Alcatel and Ericsson could use the required resources. Unforeseen events along the innovation journey need quick action in order to stay ahead or to minimalize delays if the firm continues its innovation 
efforts. A firm's capabilities are another important factor for its flexibility. To comply with the new standard, Alcatel had to reorient their work towards DMT. They had to develop new chips to enable this line-coding technique. This occurred in close cooperation with Alcatel's own chip division. Alcatel was able to react quickly on the change in external circumstances driven by the new standard. With the support of the COO, they immediately mobilized a team to develop the new chips. Alcatel relied on in-house capabilities for the ADSL development. Ericsson relied on a buyer-supplier relationship with Motorola for the ADSL chip technology. Being dependent from an external supplier increased risks and caused an additional unforeseen event for Ericsson. Motorola was not able to deliver what was asked for. As a result Ericsson had to urgently look for an alternative supplier which caused a delay in the ADSL development process.

While action and response flexibility are important for an innovation journey to succeed, our data seem to suggest that flexibility is better enacted within hierarchies compared to markets. Transaction costs linked to collaboration with external suppliers may have a significant impact on the degree to which a firm is flexible. One could argue that hierarchical mechanisms might burden responsiveness and fast decision making, which is especially important in the context of innovation management. However, it seems that hierarchical organization still provides benefits when technology and knowledge sharing or transfer is more challenging. A similar conclusion has been made by for example Sampson (2007) in her research on R\&D alliances and firm performance.

Whereas Alcatel kept the ADSL innovation process under the control of one principal, Ericsson established contractual arrangements with external partners for the delivery of critical components. In response to unforeseen events, the hierarchical organization of Alcatel enabled fluent information flow and quick responsiveness which resulted in an effectual approach characterized by flexibility. In contrast, the market organization of Ericsson in a crucial phase of the innovation journey confronted the firm with additional coordination costs and rigid contractual arrangements. Unexpected events were difficult to cope with and it took much more time to adapt or change along the innovation process. In our ADSL cases, firms have the advantage over markets to be more flexible, especially if a firm has many capabilities in-house. Our data suggests that the more capabilities a firm possesses, the more flexible the firm can act. It seems that operational flexibility is important throughout every phase in the innovation journey. Ericsson should have collaborated with Motorola in a co-development logic - which might have implied that they would have paid Motorola to speed up their development efforts. Setting/re-setting such strategic priorities is more easily done within a hierarchy (at least if senior management approves/ supports) than in a supplier-customer relationship, characterized by information asymmetries.

\subsection{Capabilities}

Innovation requires firms to develop and possess technological capabilities that enable the deployment and use of different resources and know-how (Anderson and Tushman, 1990; Song et al., 2005; Zhou \& Whou, 2010). Following the widespread advice that firms should invest in both exploitation and exploration (March, 1991; O'Reilly \& Tushman, 2013), the capabilities that result from these efforts are important for a firm's innovation strategy and journey. Moreover, 
technological capabilities not only enable innovation, they also influence development speed (Moorman \& Slotegraaf, 1999).

Teece (2017) explains that a firm's technological capabilities relate to its past technological activities. Scholars agree that a broad set of technological capabilities or competences is beneficial for continuous improvement and innovation as cross-fertilization and synergies might occur (e.g. Cohen \& Levinthal, 1990; Garcia-Vega, 2006; Patel \& Pavitt, 1997). According to Levinthal and March (1993), firms with a superior capability in a given field are more likely to search for more local, information and rely on their existing knowledge stock to gain immediate advantage.

At the same time, innovation efforts are limited by existing processes, routines and capabilities within the firm (Zhou \& Whou, 2010). A firm's managerial decisions determine how capabilities are created, shaped and deployed. Capabilities can be developed internally (O'Reilly, et al., 2009) or firms can choose to outsource them (Globerman, 1980; Phene, et al., 2012).

Our data shows that both Alcatel and Ericsson invested substantial resources in R\&D of ADSL technology and complementary technologies. ${ }^{43}$ These R\&D efforts were both of an exploitative and exploratory nature, although Alcatel obtained a stronger balance between exploitation and exploration. ${ }^{44}$ The evidence from our cases advances that technological capabilities stimulate organization learning, innovation and development speed. When the foreseen killer application "Video on Demand" collapsed, Alcatel and Ericsson reoriented their capabilities to the area of the Internet. A major difference between Alcatel and Ericsson was that Alcatel relied entirely on its own capabilities, while Ericsson accomplished partnership agreements and acquisitions according to the guiding principle of where the required capabilities could be found. Both firms had many capabilities in-house. Alcatel's management decided to build on its technological capabilities to develop the new DMT chip that was compliant with the new industry standard. They realized the chip development very quickly, far ahead of their competitors. In contrast, Ericsson's management deliberately chose to rely on an external supplier instead of using and reconfiguring its own competences for the chip development. In the end, relying on internal capabilities proved to be one of the success factors in the innovation journey of ADSL. However, an important condition is to have sufficient capabilities.

The evidence from our cases suggest that an innovation journey starts with the available resources. However, firms can adjust their resource strength with capabilities and investments in exploration and exploitation to improve their position and product. Ambidexterity or a firm's ability to both explore and exploit, seems to help during the innovation trajectory to strengthen and/or maintain the firm's position. In sum, capabilities come into play during the enacting the opportunity and commercialization phase.

43 See also chapter 3. Figure 3-1 shows how much ADSL patents both firms have and figure 3-3 shows the number of patents in the technology field of electrical engineering.

44 Figure 4-4 gives an overview of how balanced the portfolio of Alcatel and Ericsson is. 


\section{Discussion and conclusion}

Research in the technology and innovation management literature has focused on how incumbent firms should organize for innovation. The current research demonstrates the complexity of the innovation process and the outcome uncertainties in terms of technological and market success. This longitudinal comparative case study of two large established telecommunication equipment firms unfolds the process of an innovation trajectory.

This chapter contributes to the technology and innovation management literature by providing insight into the process of effectively pursuing innovation of a novel nature within incumbents. The findings show that successful innovation trajectories contain a configuration of different factors. As figure 5-5 illustrates, we identify four key time periods and five components that are closely related to each other. The figure below shows the period in which each component is particularly important.

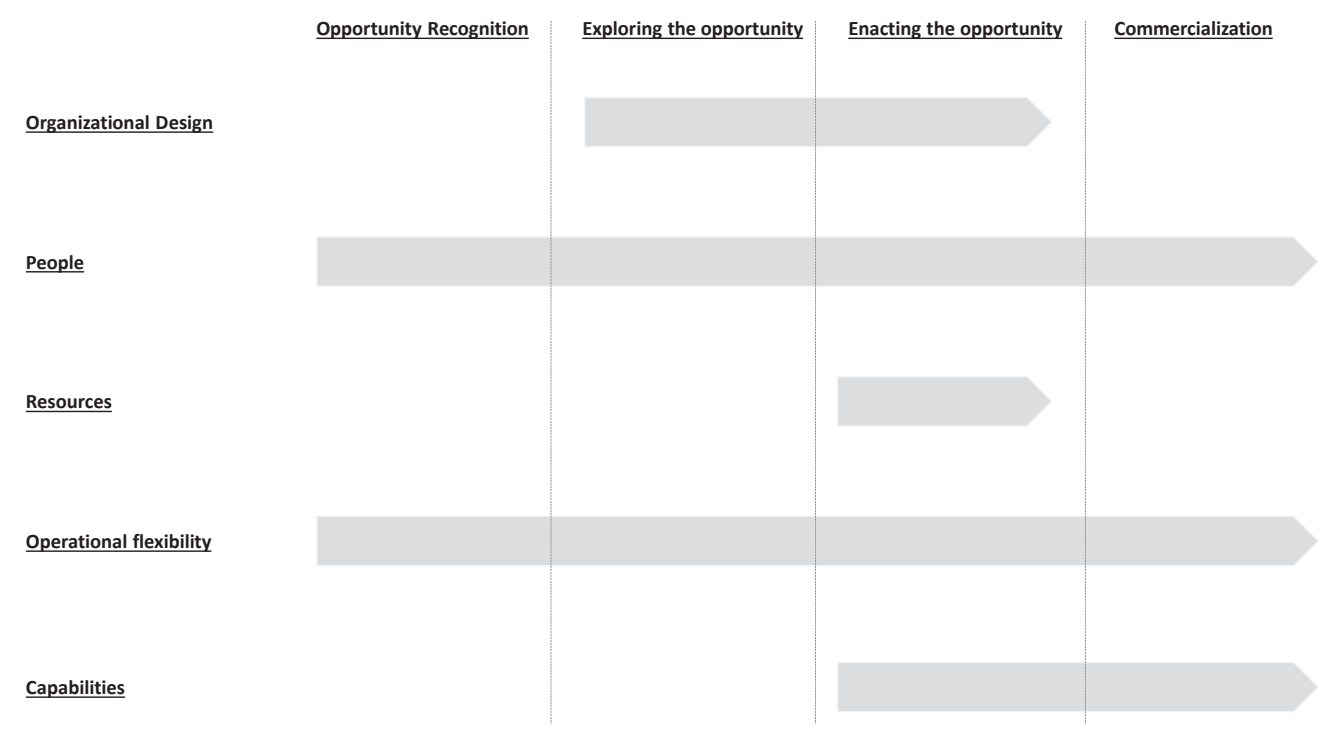

Figure 5-5: Key time periods in an innovation journey and their factors

\subsection{Theoretical implications}

The innovation management literature shows different research perspectives and numerous theoretical approaches that often apply a particular focus such as resource allocation strategies (e.g. Klingebiel \& Rammer, 2014), top management's cognitive and emotional thinking (e.g. Raffaelli, Glynn, \& Tushman, 2019), or organizational design (e.g. Tushman et al., 2010). This is making it difficult to get a comprehensive understanding of how incumbents can effectively pursue innovation of a novel nature and how top management teams and project managers influence the innovation journey. The evidence from our data shows that focusing on one or two perspectives or 
theories in isolation is not enough. The cases of Alcatel and Ericsson illustrate that there is a strong connection and path dependency between the different points of view. Our findings suggest that if we really want to help managers with the pursuit of a successful innovation trajectory, we have to look at the bigger picture and the details at the same time and over time.

Whereas initial efforts towards exploring new opportunities can effectively happen in an integrated way, our case research reveals that an organizational design of a differentiated nature becomes critical from the moment a firm decides to engage in a truly new innovation trajectory. Although various modes of structural differentiation exist, the choice for a differentiated, hybrid, arrangement characterized by semi-permeability, i.e. separation along integration, shows to be particularly beneficial. This finding refers to the added value of internal corporate venturing practices, as described by Burgelman (1983).

Recognizing and exploring new opportunities for innovation occur in the context of uncertainty. Contrary to what a traditional causation perspective assumes, an innovation process is far from linear. While the existing literature focuses to a large extent on the aspect of uncertainty and its impact on opportunity identification in the exploration phase, our empirical data illustrates that the whole process - from opportunity recognition until commercialization - is subject to unforeseen occurrences. This observation follows Van de Ven (2017) who describes the innovation journey. Firms should be aware that it is crucial to redefine innovation objectives and reconfigure resource allocation processes along the innovation trajectory. Our findings suggest that flexibility is enabled by a differentiated structure which is characterized by semi-permeability. Following Gaffard's (1990) distinction between two types of flexibility, we argue that response flexibility and action flexibility are essential components in a firm's innovation trajectory. Firms need operational flexibility to cope with unforeseen events, for any innovation journey to be effective. Their flexibility can be constrained by the organizational structure, the enactment of resources, and capabilities and abilities of the people involved in the innovation process.

Figure 5-6 summarizes the five components for developing a novel innovation trajectory (from technology to market) that we identify in this study. These components are related to each other and all influence the effective pursuit of innovation of a more novel nature within incumbents.

\subsection{Managerial implications}

Incumbent firms can combine their advantages of being established with the advantages that entrepreneurial new entrants have. For this purpose, incumbent firms should facilitate entrepreneurial dynamics, autonomy and flexibility along the innovation process. While the existing literature emphasized the importance of differentiated organizational arrangements and the enactment of resources, this paper shows that more is needed. First, the creation of a hybrid semi-permeable, structure that involves both differentiation and integration seems crucial, especially in combination with required roles in support of the innovation process. A hybrid, semi-permeable, structure allows for entrepreneurial dynamics as the innovation activities occur in an environment in which one can profit from the resources and capabilities that are available at the parent company while autonomy is given to the people responsible for the innovation process. Second, the development of a truly 


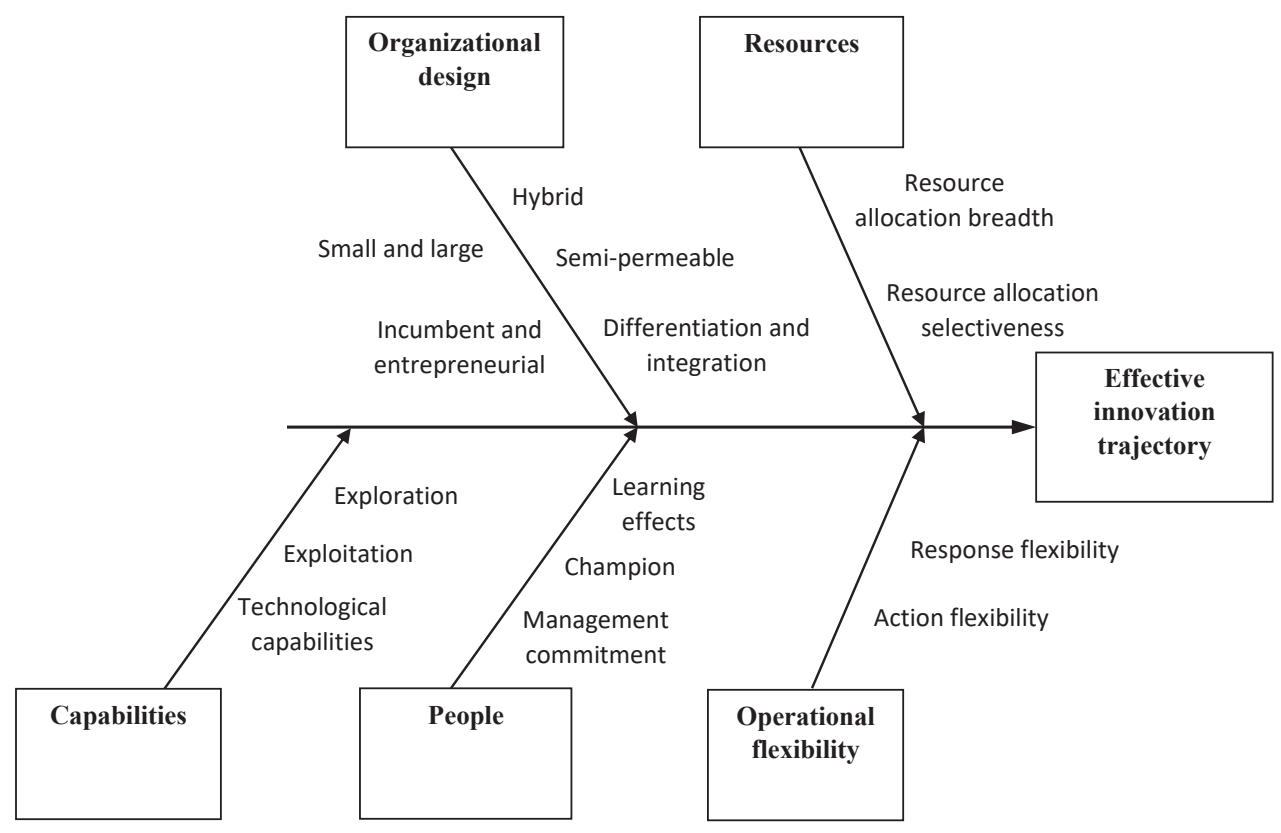

Figure 5-6: Components of an effective innovation trajectory

new innovation requires flexibility throughout the whole innovation trajectory in order to cope with unforeseen events. This implies the ability to continuously redefine innovation objectives and reconfigure resource allocation processes. Third, acknowledging the many challenges and complexity of new innovations, flexibility seems to be better enacted within hierarchies compared to markets. Fourth, building capabilities through exploitation and exploration enables innovation and increases a firm's ability to be quick in responding to markets and technological evolutions. Organizational ambidexterity or "the ability of an organization to both explore and exploit - to compete in mature technologies and markets where efficiency, control, and incremental improvement are prized and to also compete in new technologies and markets where flexibility, autonomy, and experimentation are needed" (O’Reilly \& Rushman, 2013, p.) is an important organization-level capability.

Together, these elements enable incumbent firms to cope with the difficult challenge of engaging in innovation alongside current business activities given that not all events are ex ante foreseeable when developing new technologies and products.

\subsection{Limitations and directions for future research}

Although a comparative case study design offers a fruitful method of examining the process of organizing for innovation, carefulness is required when aiming to generalize the findings based on a limited sample. We highlight that our research focus has been on incumbent firms in a typical high-velocity environment, in which incumbent firms face short product-life cycles, severe competition, and the urge to be quick in developing new products. Organizing for innovation in relatively stable environments might favor a different approach than opting for configurations of a semi-permeable nature. 
It should be remarked that our findings relate to technology and product innovations of a truly new nature, which are characterized by a high degree of uncertainty, ambiguity, and complexity. As a consequence, these findings do not apply to innovations of a more incremental character. Since this paper involves a two-case comparative study, we are very supportive towards conducting more longitudinal comparative case studies that extend and further substantiate our findings. Furthermore, an interesting opportunity for future studies lies the interaction between organizational design and product architecture, which is under-researched in the literature. Whereas several authors have argued that product architectures and organizational arrangements are mutually constituent (Baldwin \& Clark, 2000; Campagnolo \& Camuffo, 2010), and that alignment is important for the success of innovative ventures (Turnbull, 1992), this alignment of organization and technology has hardly been investigated in the literature on innovative ventures.

This chapter taps into many different literature streams due to the complexity of an innovation process. However, we could not thoroughly study every aspect from the innovation management literature. For example, technical (architectural) design choices, innovation portfolio management and open versus closed innovation were no subjects of study in this chapter. As these are important in innovation trajectories, it would be interesting for future research to deliberately include these dimensions. 


\section{References}

Anderson, P., Tushman, M., \& O’Reilly, C. 1997. Technology Cycles, Innovation Streams and Ambidextrous Organizations. In P. Anderson, \& M. Tushman (Eds.), Managing Strategic Innovation and Change. New York: Oxford University Press.

Andries, P., Debackere, K., \& Van Looy, B. 2013. Simultaneous experimentation as a learning strategy: Business model development under uncertainty. Strategic Entrepreneurship Journal, 7(4): 288-310.

Baldwin, C. Y., \& Clark, K. B. 2000. Design Rules: The Power of Modularity. Cambridge, MA: MIT Press.

Barney, J. 1991. Firm resources and sustained competitive advantage. Journal of Management, 17(1): 99-120.

Baron, R. A. 2006. Opportunity recognition as pattern recognition: How entrepreneurs "connect the dots" to identify new business opportunities. Academy of Management Perspectives, 20(1): 104-119.

Beckman, C. M., Eisenhardt, K., Kotha, S., Meyer, A., \& Rajagopalan, N. 2012. The Role of the Entrepreneur in Technology Entrepreneurship. Strategic Entrepreneurship Journal, 6(3): 203-206.

Benner, M. J., \& Tripsas, M. 2012. The influence of prior industry affiliation on framing in nascent industries: the evolution of digital cameras. Strategic Management Journal, 33(3): 277-302.

Bergek, A., Berggren, C., Magnusson, T., \& Hobday, M. 2013. Technological discontinuities and the challenge for incumbent firms: Destruction, disruption or creative accumulation? Research Policy, 42(6-7): 1210-1224.

Bingham, J. A. C. 2000. ADSL, VDSL, and Multicarrier Modulation. New York, NY: John Wiley \& Sons.

Bower, J. L. 1986. Managing the Resource Allocation Process: A Study of Corporate Planning and Investment. Boston: Harvard Business School Press.

Burgelman, R. A. 1983. A process model of internal corporate venturing in the diversified major firm. Administrative Science Quarterly, 28(2): 223-244.

Burns, T., \& Stalker, G. M. 1961. The Management of Innovation. New York: Oxford University Press Inc.

Campagnolo, D., \& Camuffo, A. 2010. The Concept of Modularity in Management Studies: A Literature Review. International Journal of Management Reviews, 12(3): 259-283.

Chen, Y. C. 1999. The Development and Standardization of Asymmetrical Digital Subscriber Line. IEEE Communications Magazine, May: 68-72.

Christensen, C. M. 1997. The innovator's dilemma: When new technologies cause great firms to fail. Boston: Harvard Business School Presss.

Christensen, C. M., \& Bower, J. L. 1996. Customer power, strategic investment, and the failure of leading firms. Strategic Management Journal, 17(3): 197-218.

Christensen, C. M., \& Overdorf, M. 2000. Meeting the challenge of disruptive change. Harvard Business Review, 78(2): 66-+.

Cohen, S. L., \& Tripsas, M. 2018. Managing technological transitions by building bridges. Academy of Management Journal, 61(6): 2319-2342.

Cucculelli, M., \& Ermini, B. 2012. New product introduction and product tenure: What effects on firm growth? Research Policy, 41(5): 808-821.

Danneels, E., \& Sethi, R. 2011. New Product Exploration Under Environmental Turbulence. Organization Science, 22(4): 1026-1039.

Eggers, J. P., \& Kaplan, S. 2009. Cognition and Renewal: Comparing CEO and Organizational Effects on Incumbent Adaptation to Technical Change. Organization Science, 20(2): 461-477.

Eggers, J. P., \& Kaplan, S. 2013. Cognition and Capabilities: A Multi-Level Perspective. The Academy of Management Annals, 7(1): 295-340.

Eisenhardt, K. M. 1989. Building theories from case-study research. Academy of Management Review, 14(4): 532-550.

Eisenhardt, K. M., \& Graebner, M. E. 2007. Theory building from cases: Opportunities and challenges. Academy of Management Journal, 50(1): 25-32.

Fuentelsaz, L., Garrido, E., \& Maicas, J. P. 2015. Incumbents, technological change and institutions: How the value of complementary resources varies across markets. Strategic Management Journal, 36(12): 1778-1801.

Gaffard, J. L. 1990. Économie industrielle et de l'innovation. Paris: Dalloz.

Galatioto, R. 1996. Full Service Networks ADSL/xDSL. (internal document). 
Garrett, R. P., \& Neubaum, D. O. 2013. Top Management Support and Initial Strategic Assets: A Dependency Model for Internal Corporate Venture Performance. Journal of Product Innovation Management, 30(5): 896-915.

Gilbert, C. G. 2005. Unbundling the structure of inertia: Resource versus routine rigidity. Academy of Management Journal, 48(5): 741-763.

Goralski, W. J. 2002. ADSL \& DSL Technologies (2 ed.). Berkeley: McGraw-Hill.

Howell, J. M., \& Higgins, C. A. 1990. Champions of technological innovation. Administrative Science Quarterly, 35(2): 317-341.

Jansen, J. J. P., Kostopoulos, K. C., Mihalache, O. R., \& Papalexandris, A. 2016. A Socio-Psychological Perspective on Team Ambidexterity: The Contingency Role of Supportive Leadership Behaviours. Journal of Management Studies, 53(6): 939-965.

Jansen, J. J. P., Tempelaar, M. P., van den Bosch, F. A. J., \& Volberda, H. W. 2009. Structural Differentiation and Ambidexterity: The Mediating Role of Integration Mechanisms. Organization Science, 20(4): 797-811.

Janssen, M., Stoopendaal, A. M. V., \& Putters, K. 2015. Situated novelty: Introducing a process perspective on the study of innovation. Research Policy, 44(10): 1974-1984.

Klingebiel, R., \& Rammer, C. 2014. Resource allocation strategy for innovation portfolio management. Strategic Management Journal, 35(2): 246-268.

Kor, Y. Y., \& Mesko, A. 2013. Dynamic managerial capabilities: Configuration and orchestration of top executives' capabilities and the firm's dominant logic. Strategic Management Journal, 34(2): 233-244.

Lavie, D., Stettner, U., \& Tushman, M. L. 2010. Exploration and Exploitation Within and Across Organizations. Academy of Management Annals, 4: 109-155.

Lawrence, P. R., \& Lorsch, J. W. 1967. Differentiation and integration in complex organizations. Administrative Science Quarterly, 12: 1-47.

March, J. G. 1991. Exploration and exploitation in organizational learning. Organization Science, 2(1): 71-87.

Miller, C. C., Cardinal, L. B., \& Glick, W. H. 1997. Retrospective reports in organizational research: A reexamination of recent evidence. Academy of Management Journal, 40(1): 189-204.

Murray, F., \& Tripsas, M. 2004. The exploratory processes of entrepreneurial firms: The role of purposeful experimentation. Business Strategy over the Industry Life Cycle, 21: 45-75.

O’Reilly, C. A., \& Tushman, M. L. 2004. The Ambidextrous Organization. Harvard Business Review, 82(4): 74-81.

O’Reilly, C. A., \& Tushman, M. L. 2011. Organizational Ambidexterity in Action: How managers explore and exploit. California Management Review, 53(4): 5-+.

Pentland, B. T. 1999. Building process theory with narrative: From description to explanation. Academy of Management Review, 24(4): 711-724.

Pettigrew, A. M. 1990. Longitudinal field research on change: Theory and practice. Organization Science, 1(3): 267-292.

Raffaelli, R., Glynn, M. A., \& Tushman, M. 2019. Frame flexibility: The role of cognitive and emotional framing in innovation adoption by incumbent firms. Strategic Management Journal, 40(7): 1013-1039.

Roberts, E. B., \& Fusfeld, A. R. 1980. Critical functions: needed roles in the innovation process, Working paper (Sloan School of Management) 1129-80B. Cambridge, Mass.: Alfred P. Sloan School of Management, Massachusetts Institute of Technology.

Rothaermel, F. T. 2001. Complementary assets, strategic alliances, and the incumbent's advantage: an empirical study of industry and firm effects in the biopharmaceutical industry. Research Policy, 30(8): 1235-1251.

Sampson, R. C. 2007. R\&D alliances and firm performance: The impact of technological diversity and alliance organization on innovation. Academy of Management Journal, 50(2): 364-386.

Schumpeter, J. A. 1934. The theory of economic development. Cambridge, MA: Harvard University Press.

Schumpeter, J. A. 1950. Capitalism, Socialism and Democracy. New York: Harper Brothers.

Sirmon, D. G., Hitt, M. A., \& Ireland, R. D. 2007. Managing firm resources in dynamic environments to create value: Looking inside the black box. Academy of Management Review, 32(1): 273-292.

Sirmon, D. G., Hitt, M. A., Ireland, R. D., \& Gilbert, B. A. 2011. Resource Orchestration to Create Competitive Advantage: Breadth, Depth, and Life Cycle Effects. Journal of Management, 37(5): 1390-1412.

Spescha, A., \& Woerter, M. 2019. Innovation and firm growth over the business cycle. Industry and Innovation, 26(3): 321-347. 
Srivastava, M. K., \& Gnyawali, D. R. 2011. When do relational resources matter? Leveraging portfolio technological resources for breakthrough innovation. Academy of Management Journal, 54(4): 797-810.

Starr, T., Cioffi, J. M., \& Silverman, P. J. 1999. Understanding Digital Subscriber Line Technology. New Jersey: Prentice Hall.

Summers, C. K. 1999. ADSL Standards, Implementation, and Architecture (1 ed.). Boca Raton, Florida: CRC Press.

Taylor, A., \& Helfat, C. E. 2009. Organizational Linkages for Surviving Technological Change: Complementary Assets, Middle Management, and Ambidexterity. Organization Science, 20(4): 718-739.

Teece, D. J. 1986. Profiting from technological innovation: Implications for integration, collaboration, licensing and public policy. Research Policy, 15(6): 285-305.

Tripsas, M. 1997. Unraveling the process of creative destruction: Complementary assets and incumbent survival in the typesetter industry. Strategic Management Journal, 18: 119-142.

Tripsas, M., \& Gavetti, G. 2000. Capabilities, cognition, and inertia: Evidence from digital imaging. Strategic Management Journal, 21(10-11): 1147-1161.

Tushman, M., Smith, W. K., Wood, R., Westerman, G., \& O’Reilly, C. 2010. Organizational design and innovation streams. Industrial and Corporate Change, 19: 1331-1366.

Tushman, M. L., \& Anderson, P. 1986. Technological discontinuities and organizational environments. Administrative Science Quarterly, 31(3): 439-465.

Tzuo, T. 2004. Technological Evolution. In R. A. Burgelman, C. M. Christensen, \& S. C. Wheelwright (Eds.), Strategic Managment of Technology and Innovation: 157-171. New York: McGraw-Hill Irwin.

Utterback, J. M. 1994. Mastering the Dynamics of Innovation. Boston: Harvard Business School Press.

Van de Ven, A. H. 2017. The innovation journey: you can't control it, but you can learn to maneuver. InnovationManagement Policy \& Practice, 19(1): 39-42.

Van Looy, B., Martens, T., \& Debackere, K. 2005. Organizing for Continuous Innovation: On the Sustainability of Ambidextrous Organizations. Creativity and Innovation Management, 14(3): 208-221.

Van Maanen, J. 1979. The Fact of Fiction in Organizational Ethnography. Administrative Science Quarterly, 24(4): 539-550.

Vuori, T. O., \& Huy, Q. N. 2016. Distributed Attention and Shared Emotions in the Innovation Process: How Nokia Lost the Smartphone Battle. Administrative Science Quarterly, 61(1): 9-51.

Wernerfelt, B. 1984. A resource-based view of the firm. Strategic Management Journal, 5(2): 171-180.

Wernerfelt, B. 2013. Small forces and large firms: Foundations of the RBV. Strategic Management Journal, 34(6): 635-643.

Westerman, G., McFarlan, F. W., \& Iansiti, M. 2006. Organization design and effectiveness over the innovation life cycle. Organization Science, 17(2): 230-238.

Yin, R. K. 2009. Case study research: design and methods (4 ed.). Thousand Oaks, CA: Sage. 


\section{Chapter 6}

Conclusion 
"You need an innovation strategy. It's the only way to make sound trade-off decisions and choose the right practices" (Pisano, 2015, p 44).

An innovation strategy relates to the sum of strategic choices about to what extent, and how, a firm attempts to use innovation to pursue its business strategy. This dissertation shows how incumbent firms can reach innovation strategy effectiveness by considering four different perspectives: timing, location, technology and path. It also shows that management has significant impact on the innovation trajectory of their company and how a higher effectiveness of their innovation efforts can be achieved while exploring and exploiting new opportunities.

\section{Timing}

The various longitudinal studies in this dissertation show that exploration and exploitation can be organized in different ways over time. As a result, there are several strategies to engage in both exploratory and exploitative innovation activities, or being ambidextrous. It makes that achieving ambidexterity is more feasible than one might think. There appear to be differences in prevalence between industries. As chapter two concludes, it seems that manufacturing firms more likely choose a simultaneous approach, while service firms tend to opt more for a sequential method, shifting focus from exploration to exploitation later in time and vice versa. The qualitative insights from chapter two suggest that the choice for different forms of ambidexterity seems to depend on managerial judgement, available resources and environmental circumstances. Incumbent firms in high-tech industries are more likely to organize simultaneously for exploration and exploitation. This is also confirmed and further examined in the other three studies.

We find no relation between the timing of a firm's exploration and exploitation activities and a firm's financial performance in the short term, as examined in chapter two. However, as the ADSL innovation journey of Alcatel illustrates in chapter five, market success can occur immediately after the introduction of an innovation on the market. Furthermore, chapter five illustrates that the innovation process from idea to finished product is accelerated by a simultaneous approach in which cross-fertilization and synergies can arise between the exploration and exploitation activities of a firm. Enabling these cross-fertilizations and synergies seems to be important for a firm's technological performance as is suggested by chapter three.

With respect to timing, an effective innovation strategy can involve both a simultaneous or sequential approach of exploration and exploitation. 


\section{Location}

The impact of where exploration and exploitation take place, or the location of a firm's innovation activities, matters too. Studying large R\&D intensive manufacturing firms, chapter three shows that firms exhibiting greater geographic proximity between technology exploration and exploitation, i.e. spatial ambidexterity, display an elevated level of technological performance. The cases of Alcatel and Ericsson show a similar finding. Alcatel centralized its innovation efforts. In contrast, Ericsson's R\&D activity for ADSL was spread over multiple locations in different countries. It was clearly more difficult for Ericsson to make fast technological progress and to achieve a strong involvement of management and staff due to the distance and subsequent high coordination costs.

In conclusion, organizing exploration and exploitation in geographic proximity contributes to innovation strategy effectiveness.

\section{Technology}

Exploring or exploiting new opportunities and technology development usually go hand in hand. Technology is important but a successful innovation journey and innovation strategy effectiveness require more than technology. Chapter four shows that firms with the strongest patent portfolio, in terms of number of patents, patent quality and novelty of the technology, do not automatically become market leader in a new market, nor do they have the certainty that they will capture any significant market share. A firm's technological portfolio is important, but market success cannot be reduced to success in technology development. In addition, chapter four reveals that a consistent balance between technological development of an exploratory and exploitative nature matters more than displaying a strong balance at certain times during the phase of an emerging market. Chapter five concludes that the innovation journey of ADSL would not exist without technological development, but other factors play an important role as well in order to have a successful outcome of an innovation trajectory in terms of product and market success. Organizational design, people, resources, operational flexibility and also non-technological capabilities together have a decisive impact.

Thus, technology is a necessary but not sufficient condition for an effective innovation strategy.

\section{Path}

While in chapter five, the Alcatel-Ericson case study specifically focusses at the path these firms took, the relevance of the innovation path is a recurring theme in all chapters. For example, examining the importance of technological development in a firm's innovation strategy towards entering a new high-tech market, chapter four shows that market leadership in an emerging hightech market (ADSL) is based on more than just possessing the required technological capabilities 
of the technology at hand and complementary technologies. There is a relation between a firm's patent portfolio and market share. However, market success is not merely the result of technology success. The events and decisions that occur along the innovation journey come into play too, for which chapter four provides further details.

An innovation strategy includes the plan, but the actual innovation trajectory may look different. It is not only the strategy, but also the execution that matters. While the strategy dictates the journey, the journey should also inform the strategy. For example, as described in chapter five, Alcatel and Ericsson both planned to focus on ADSL development for Video on Demand applications. In the first half of their innovation journey, they were confronted with the need to change focus from Video on Demand to the Internet. No one could have predicted this when they created their innovation strategy. During their innovation trajectory, they had to change the set-up of their innovation journey and strategy. Companies are very often confronted with unforeseen events or circumstances. It is about being able to deal with this and still be able to complete an innovation trajectory according to the expectations. The study in chapter five concludes that an innovation journey involves four key time periods: opportunity recognition, exploring the opportunity, enacting the opportunity, and commercialization of the technology. Along the innovation journey, we distinguish five components that are closely related to each other: organizational design, people, resources, operational flexibility and capabilities.

Also chapter two shows the importance of the path firms take, whether it is pursing exploration and exploitation simultaneously or sequentially. Strategic choices that decision makers in a firm take, impact the innovation path project teams can and should follow to reach the best outcomes. Without taking this path dependency in consideration, one cannot outline an effective innovation strategy.

In sum, this dissertation concludes that in order to reach innovation strategy effectiveness, firms can engage in exploration and exploitation through a simultaneous or sequential way, should consider to opt for spatial proximity of their exploratory and exploitative activities, need to invest in technological development, and adjust these choices based on what happens during the execution of an innovation project.

A successful innovation journey from idea to market requires more than technological capabilities. While an innovation strategy or a sound innovation plan is crucial for each firm (in order to reach an outcome in accordance to the business strategy), a strategy is rarely implemented exactly as planned. Firms face unforeseen events along the innovation path. Both innovation strategy and innovation journey must constantly be coordinated.

\section{Contributions and implications}

The contribution of this dissertation is that it adds to the existing knowledge about how incumbent firms can effectively develop and enact an innovation strategy. Following prior research (e.g. Birkinshaw \& Gibson, 2004; Gupta, Smith, \& Shalley, 2006; Lavie, Stettner, \& Tushman, 2010; Luger, Raisch, \& Schimmer, 2018; Mathias, McKenny, \& Crook, 2018), the four empirical studies 
underline the importance for firms to combine exploratory and exploitative activities. The main contribution is therefore that this dissertation suggests how this can best be achieved and what aspects contribute to innovation strategy effectiveness.

\subsection{Theory}

The need to explore and exploit is addressed from many angles in the literature, related to innovation, organizational design, organizational learning, competitive advantage and firm survival. Whereas all chapters provide insights with regard to effective innovation strategies for incumbent firms, each study contributes to a particular area in the literature stream of innovation management and strategy. Chapter two adds to the literature on organizing for explorationexploitation and innovation behavior of manufacturing versus service firms. Chapter three contributes to the literature on organizing for organizational ambidexterity. Chapter four adds to the literature on the relationship between technology and market share. Finally, chapter five contributes to the literature on the process of the effective pursuit of an innovation trajectory.

One might question: "What is the best direction to examine effective innovation strategies for incumbent firms?". In fact, each research track provides valuable insights, all involving a particular research method. It is the combination of these research directions that allows for a well-founded answer on how incumbent firms can effectively pursue their innovation strategy and journey by making the right choices in terms of time, location, technology and path. Our findings suggest the relevance of an encompassing perspective, that includes time, location, technology and the path.

All four studies rely on a longitudinal research approach involving both an intra and external firm perspective. This dissertation shows the relevance of applying multiple methodologies for examining one topic. For example, the conclusion that a firm's technological performance benefits from geographic proximity of its exploration and exploitation, is reached thanks to longitudinal patent research. The quantitative data observation that market leadership in an emerging high-tech market does not coincide with technological leadership, underlines the importance of conducting case study research to gain essential insights that cannot be revealed through an econometrical method. Acknowledging that applying different methods and firm perspectives lead to a more indepth understanding, this dissertation shows that a mixed method allows to better understand a complex domain, innovation management, both on a theoretical and a practical level with respect to issues as what needs to be done when and where.

\subsection{Practice}

The findings of the four studies provide useful managerial advice. All four studies show that it is a must for firms to invest in both exploratory and exploitative activities, regardless of being active in one or more emerging, new or mature markets, or being a service or manufacturing firm. The development of a strategy is not enough. In line with the managerial advice of for example Brandenburger (2019) and Pisano (2015), this dissertation shows that strategy effectiveness largely depends on its execution. Besides, the four studies reveal what exactly helps incumbent firms to experience an effective innovation journey and strategy. 
What do timing, location, technology and path imply for managers that should develop and execute an innovation strategy?

Relying on managerial judgement, available resources and environmental circumstances, firms can decide to follow a simultaneous our sequential approach in their exploration and exploitation efforts. Taking into account the firm- and industry specific context, both approaches seem to be equally viable.

When firms decide on the organizational set-up of their exploration and exploitation efforts, spatial proximity should be taken into account. For example, Bekaert, a world market and technology leader in steel wire transformation and coating technologies, recently announced organizational restructuring in order to become more agile and cost-efficient. In particular, the firm intends to move production-related test lab activities and spare parts activities to main production plants. Moreover, Bekaert will transfer R\&D to 'key learning plants' in order to speed up the development and bring-to-market process of product and process innovations (Bekaert, 2019). From this press release, it is clear that Bekeart wants to organize themselves such that their exploratory and exploitative efforts occur in spatial proximity. Bekaert's strategic movement aligns with the outcome of this dissertation. As Bekaert recognizes, organizing for exploration and exploitation in spatial proximity facilitates spillovers and synergies which can lead to an elevated level of innovation performance, in addition to cost efficiency.

There is more than technology. It is important to be active in different technology fields, yet, at the same time, one might not lose focus. For example, chapter four shows that Siemens had a tremendously broad patent portfolio. In all likelihood, this portfolio was too broad to effectively enact on the emerging ADSL market, at least when compared to Alcatel, which also covered a wide range of technologies but predominantly within the same umbrella of electrical engineering. In $\mathrm{R} \& \mathrm{D}$ intensive industries, firms will not automatically become market leader if they possess the most patents and the patents with the highest value. Having the technological capabilities is necessary, but no sufficient condition to gain market share or market leadership.

Incumbent firms should consider a sophisticated and dynamic interplay of critical ingredients when carrying out an innovation trajectory. While executing upon their innovation strategy, organizational design, people, resources, operational flexibility and capabilities have to managed appropriately as chapter four shows.

\section{Limitations and directions for future research}

Each chapter aims to add to the existing knowledge about effective innovation strategies for incumbent firms. Like most scientific research, this dissertation is subject to some limitations that at the same time provide ideas for future research.

One of the limitations pertains to the operationalization of our key concepts such as exploration, exploitation, technological leadership, technological and firm performance. The literature shows that these concepts can be measured in many different ways (e.g. Fontana \& 
Vezzulli, 2016; Junni, Sarala, Taras, \& Tarba, 2013). In our choice of operationalization we were limited to the possibilities of our data.

Another limitation is the time period that we considered in our longitudinal studies. These where chosen based on the availability of data in most cases, or the most appropriate time span for example for chapter three. We did not address the impact of economic booms and busts that occurred during some of these time periods.

While we investigated various industries, services versus manufacturing and ADSL technology, we did not look at industry impacts in a systematic manner.

A recent growing body of literature in service innovation illustrates a catching-up process compared to the many studies carried out in manufacturing firms. However, much needs to be further explored to obtain a better understanding of innovation in service firms.

This dissertation relies on different methodological approaches of a quantitative and qualitative nature. We argue that mixed methodologies are very valuable in studying innovation management and should be more often applied. A process approach (Van de Ven, 1999, 2017), is still insufficiently practiced in the field of innovation management. Also, chapter three illustrates the need for appropriate analytical tools to study data driven case-studies. This chapter also shows how difficult it is to collect such data. For example, our data set consisted of a set of international firms, yet especially for the Asian companies that entered the market at a later stage, there was no public data available about company performance. Accessibility is a problem too. We were able to set up in-depth case interviews within Alcatel and Ericsson. However, it would have been valuable to also know what happened at Siemens and why.

The past decade shows many changes in the nature and locus of innovation (Benner \& Tushman, 2015). For example, the rise of community-based innovation. Regardless of these evolutions, firms still need to develop a sound innovation strategy and need to have the capacity to turn ideas into successes. While this was the focus of the dissertation, it would be interesting to expand current insights about to what extent, how and with which effect, incumbent firms integrate these practices. 


\section{References}

Bekaert. (2019). Bekaert announces restructuring plans Belgium [Press release]. Retrieved from https://www. bekaert.com/en/about-us/news-room/news/bekaert-announces-restructuring-plans-belgium

Benner, M. J., \& Tushman, M. L. (2015). Reflection on the 2013 decade award- "exploitation, exploration, and process management: The productivity dilemma revisited" ten years later. Academy of Management Review, 40(4), 497-514. doi: 10.5465/amr.2015.0042

Birkinshaw, J., \& Gibson, C. (2004). Building ambidexterity into an organization. Mit Sloan Management Review, 45(4), 47-+.

Brandenburger, A. (2019). Strategy Needs Creativity. Harvard Business Review, 97(2), 57-+.

Fontana, R., \& Vezzulli, A. (2016). Technological leadership and persistence in product innovation in the Local Area Network industry 1990-1999. Research Policy, 45(8), 116-131. doi: 10.1016/j.respol.2016.04.002

Gupta, A. K., Smith, K. G., \& Shalley, C. E. (2006). The interplay between exploration and exploitation. Academy of Management Journal, 49(4), 693-706. doi: 10.2307/20159793

Junni, P., Sarala, R. M., Taras, V., \& Tarba, S. Y. (2013). Organizational ambidexterity and performance: A metaanalysis. Academy of Management Perspectives, 27(4), 299-312. doi: 10.5465/amp.2012.0015

Lavie, D., Stettner, U., \& Tushman, M. L. (2010). Exploration and Exploitation Within and Across Organizations. Academy of Management Annals, 4, 109-155. doi: 10.1080/19416521003691287

Luger, J., Raisch, S., \& Schimmer, M. (2018). Dynamic Balancing of Exploration and Exploitation: The Contingent Benefits of Ambidexterity. Organization Science, 29(3), 449-470. doi: 10.1287/orsc.2017.1189

Mathias, B. D., McKenny, A. F., \& Crook, T. R. (2018). Managing the tensions between exploration and exploitation: The role of time. Strategic Entrepreneurship Journal, 12(3), 316-334. doi: 10.1002/sej.1287

Pisano, G. P. (2015). You need an innovation strategy. Harvard Business Review, 93(6), 44-54.

Van de Ven, A. H. (1999). The Innovation Journey. Oxford, UK: Oxford University Press.

Van de Ven, A. H. (2017). The innovation journey: you can't control it, but you can learn to maneuver. InnovationManagement Policy \& Practice, 19(1), 39-42. doi: 10.1080/14479338.2016.1256780 